\title{
SUBTRIBAL, GENERIC AND SUBGENERIC COMPOSITION OF DARKLING BEETLES OF THE TRIBE HELOPINI (COLEOPTERA: TENEBRIONIDAE) IN THE EASTERN PALAEARCTIC REGION
}

\author{
Maxim Nabozhenko ${ }^{1,2}$ and Kiyoshi Ando 3 \\ ${ }^{1}$ Caspian Institute of Biological Resources of the Russian Academy of Science \\ Gadzhiev str.45, Makhachkala, Republic of Dagestan, 367000, Russia; E-mail: nalassus@mail.ru \\ ${ }^{2}$ Dagestan State University, M. Gadzhiev str. 43a, Makhachkala \\ Republic of Dagestan, 367000 Russia \\ ${ }^{3}$ Entomological Laboratory, Faculty of Agriculture, Ehime University \\ Tarumi 3-5-7, Matsuyama, 790-8566 Japan; E-mail: tenebrio@entom.biz-web.jp
}

A review of the following Eastern Palaearctic (China, Russian Far East, Korean Peninsula, Japan and Taiwan) genera of the tribe Helopini (Coleoptera: Tenebrionidae) is given: subtribe Helopina: Nipponohelops Masumoto, Ando et Akita, 2006, Apterotarpela Kaszab, 1954, Catomus Allard, 1876, Stenohelops Reitter, 1922; subtribe Cylindrinotina: Nalassus Mulsant, 1854, and Asialassus gen. n. (type species Helops cordicollis Marseul, 1876). As a result the following combinations and synonymy are proposed (all from the genus Tarpela Bates, 1870): Apterotarpela clypealis (Kaszab, 1954), comb. nov., Apterotarpela subasperipennis (Kaszab, 1954), comb. nov., Nalassus (Nalassus) brunneus brunneus (Marseul, 1876), comb. n., Nalassus (Nalassus) brunneus konoi (Nakane, 1963), comb. n., Nalassus (Nalassus) elegantulus (Lewis, 1894), comb. n., Nalassus (Nalassus) formosanus (Masumoto, 1981), comb. n., Nalassus (Nalassus) akitai (Masumoto, 1998), comb. n., Nalassus (Nalassus) kawabatai (Akita et Masumoto, 2012), comb. n., Nalassus (Nalassus) zoltani (Masumoto, 1981), comb. n., Nalassus (Nalassus) pilushenmuus (Masumoto, Akita and Lee, 2017), comb. n., Nalassus (Nalassus) yuanfengus (Masumoto, Akita et Lee, 2017), comb. n., Nalassus (Nalassus) xiaoxueshanus (Masumoto, Akita et Lee, 2017), comb. n., Nalassus (Nalassus) dongurii (Masumoto, Akita et Lee, 2017), comb. n., Nalassus (Nalassus) merkli (Masumoto, Akita and Lee, 2017), comb. n., Nalassus (Nipponalassus) andoi (Masumoto, 1993), comb. n., Nalassus (Nipponalassus) lewisi (Masumoto, 1993), comb. n., Asialassus cordicollis (Marseul, 1876), comb. n., Asialassus amamiensis (Kaszab, 1964), comb. n., Asialassus kimurai (Masumoto, 1996), comb. n. (= Tarpela tokunoshimana Masumoto et Akita, 2001: 20, syn. n.), Asialassus tsushimanus (Nakane, 1979), comb. n., Asialassus todai (Ando, 2006), comb. n., Asialassus adachii (Akita et Masumoto, 2009), comb. n. A new subgenus of the genus Nalassus is proposed: Nipponalassus subgen. n. (type species Tarpela andoi Masumoto, 1993). Two new species are described from China: Catomus (Sinocatomus) stanislavi sp. n. and Stenohelops (Stenomaleis) chinensis sp. n. Morphological diagnoses and keys are given to subtribes, genera and species.

Key words: darkling beetles, Helopini, Eastern Palaearctic region, taxonomy.

\section{INTRODUCTION}

Darkling beetles of the tribe Helopini are widespread in the Holarctic region, in part of the Neotropical and the Oriental regions, and some species 
are known from the Afrotropical region (Ethiopia, Kenya, Mozambique and Seychelles). Species of the tribe Helopini occur mainly in the Palaearctic part of Eastern Asia (Nabozhenкo \& Löbl 2008), four species were described from Vietnam (FAirmaire 1888, Pic 1925, Kaszab 1980) and one from Thailand (MAsuмото 1998). To date twenty species of four genera are known in the Eastern Palaearctic region: Nalassus Mulsant, 1854, Tarpela Bates, 1870, Apterotarpela Kaszab, 1954 and Nipponohelops Masumoto, Ando et Akita, 2006. The most diverse genus is Tarpela, which is widespread in Japan, Taiwan and Korea.

Antorne (1949) was the first specialist who developed a classification of the tribe Helopini based on the structure of male genitalia and separated two groups of genera with 'nalassoid' and 'helopioid' types of genitalia. EsPAÑOL (1956) gave names for these groups, tribes Helopini and Cylindrinotini, which are recently interpreted into two subtribes within the tribe Helopini (Nabozhenko \& Löвl 2008). The modified classification based on Antoine's investigations has been followed by most specialists (Ardorn 1958, EsPAÑol 1961, Nabozhenko 2005, Nabozhenкo \& Löвl 2008, etc.). Nabozhenko and co-authors (Nabozhenko 2005, Nabozhenko \& Gurgenidze 2006, Purchart \& NAвоzнеNко 2012) additionally provided support for this classification based on the structure of female genital tubes and structures of larvae. Partial improvement of the classification of American species of Helopini (some species were transferred from the genus Helops Fabricius, 1775 s. l. of the subtribe Helopina to the genus Nalassus of the subtribe Cylindrinotina) was also made using structures of the head, male genitalia, terminalia and female genital tubes (NABоzHenko et al. 2016). Some East Asian species were transferred from the genera Tarpela and Cylindronotus Faldermann, 1837 to the genus Nalassus based on these structures (NABozhenкo 2012, Nabozhenкo \& Ivanov 2015). Thus, the genus Nalassus, which was previously considered as Western Palaearctic group (Reitter 1922, Medvedev 1987), has the Holarctic range as well as the subtribe Cylindrinotina.

The subtribe Helopina is distributed in the Holarctic, Afrotropical, and partially in the Oriental and Neotropical regions. The taxonomic position of some African genera is unclear (Schawaller 2012). Position of the genus Afrohelops Schawaller, 2012 with two species from Kenya and Mozambique is also unclear because male genitalia were not described, and they were figured schematically and only dorsally and laterally; female genital tubes were also not figured. It is likely that Afrohelops belongs to the subtribe Cylindrinotina since the parameres of species in this genus are separated by a distinct suture.

We established that the most species of Asian Helopini belong to the different genera, and not to Tarpela, based on the structure of head, male genitalia, terminalia and female genital tubes. The range of the genus Tarpela comprises North and Central America. The type species of the genus Tarpela 
brownii Bates, 1870 was described from Nicaragua. This species belongs to the subtribe Helopina and has 'helopioid' male genitalia, terminalia and female genital tubes, while the most of Palaearctic "Tarpela" have 'nalassoid' ones and belong to the subtribe Cylindrinotina. Polyphyly of the genus Tarpela was partly shown in the papers of Cifuentes-Ruiz et al. (2014) and Naвоzhenкo and Ivanov (2015). At the first time, a species Tarpela cordicollis (Marseul, 1876) was interpreted as a member of the subtribe Cylindrinotina. Within the Eastern Palaearctic Helopini only the genera Apterotarpela, Nipponohelops, Catomus and Stenohelops belong to the subtribe Helopina. Position and differences of Asian 'Tarpela' from the real American genus Tarpela are discussed below.

In the present work, morphological characteristics of subtribes and genera of the tribe Helopini (except for some recently described species) are given for taxa distributed in the Eastern Palaearctic region.

The Oriental species Tarpela asperipennis Fairmaire, 1888, T. regularis Pic, 1925 (= T. semirufescens Pic, 1929), T. helopioides Kaszab, 1980, T. vietnamica Kaszab, 1980, T. becvari Masumoto, 1996 will be revised in a separate work.

\title{
MATERIAL AND METHODS
}

The depositories of the specimens and its abbreviations used in this study are as follows: MNHP, Muséum National d'Histoire Naturelle (Paris, France); CKA, private collection of Kiyoshi Ando (Osaka, Japan); CN, private collection of Maxim Nabozhenko (Makhachkala, Russia); ZIN, Zoological Institute of the Russian Academy of Science (St Petersburg, Russia); BNHM, Natural History Museum (London, Great Britain); HNHM, Department of Zoology, Hungarian Natural History Museum (Budapest, Hungary); EUM, Ehime University Museum (Matsuyama, Japan); Osaka Museum of Natural History (Osaka, Japan); NMNS, National Museum of Nature and Science, Tsukuba (Japan); NHMB, Natural History Museum of Basel (Switzerland); MHU, Hokkaido University Museum, Hokkaido University (Sapporo, Japan); SNMS, Staatliches Museum für Naturkunde (Stuttgart, Germany); CSB, private collection of Stanislav Bečvář (Prague, Czech Republic).

\section{RESULTS AND DISCUSSION}

\author{
Tribe Helopini Latreille, 1802 \\ Subtribe Helopina Latreille, 1802
}

(Figs 1-6)

General differential morphology. Adult. Head always without posterior grooves beginning at lower aspect of the eyes. Labrofrontoclypeal membrane exposed (labrofrontoclypeal membrane originate under the anterior edge of the frontoclypeus) in Palaearctic species and hidden (labrofrontoclypeal membrane originates from inner side of the frontoclypeus) in many Nearctic species. Abdominal ventrite 5 is beaded dorsally and along margin. 
Male genitalia. Apical piece with strong spines or setae directed toward the base (Figs $4 A, B, G, H, L, M)$. Alae of apical piece are very long, merged, completely concealing median lobe, reaching base of basal piece (Figs $4 A, G, L)$. Basal piece separated from alae by connecting membrane along whole length. Median lobe acuminate or rounded apically, often with two apices, with sclerotized baculi, which are connected in basal third (Figs 4C,I,N).

Female genital tubes. Spermatheca has two or more long branches. Some genera have the one-way valve between spermathecal and accessory gland ducts (NABOZHENKo et al. 2016).

Larva. Abdominal segment IX without small cylindrical or conical protuberances at base of urogomphi. Abdominal tergit VIII often with one or two protuberances.

Comments. We didn't use characters of ovipositor and defensive glands, which are important in higher classification of Tenebrionidae (KENDALL 1974, MAtTHEws et al. 2010 etc.). The ovipositor is very similar within different genera of Helopini. Some differences can be found in a size and form of gonostyli, but these characters are variable even in a one genus (NABOzHenko 2002, CifuentesRuiz et al. 2014). Only psammobiotic Xanthohelops karacumicus Nabozhenko et Medvedev, 2006 has unusual within Heloini fossorial ovipositor, with reduced gonostyli and strongly sclerotized and acute apical coxites (NABOzHENKO 2006). Defensive glands were not study, but Kendall (1974) indicated close similarity of glands in Nalassus laevioctostriatus (Goeze, 1777) (subtribe Cylindrinotina) and Helops caeruleus (Fabricius, 1775) (subtribe Helopina).

Key to genera of the subtribe Helopina of Eastern Palaearctic

1. Base of elytra without short vertical border, humeral angles indistinct (Figs 5A-E)

Catomus

- Base of elytra with distinct vertical border, humeral angles distinct (Figs $3 \mathrm{~A}, \mathrm{C}, 6 \mathrm{~A}, \mathrm{~B})$

2. Eighth elytral interval connected with elytral margin apically (Figs 3D,E). Male protarsi not widened. Apical piece of aedeagus acute apically (Figs $4 \mathrm{~A}, \mathrm{~B})$. Male antennae short, not reaching half of elytral length

Apterotarpela

- $\quad$ Eighth elytral interval connected with third or second interval apically. Male protarsi widened (Fig. 6A). Apical piece of aedeagus wide, widely rounded apically (Figs 4G,H,L,M). Male antennae long, reaching half of elytral length

3. Body smaller (8-11 mm), shiny, brown, with weak bronze shade (Fig. 6)

Stenohelops

- $\quad$ Body larger (more than $12 \mathrm{~mm}$ ), head and pronotum dull, elytra weakly shiny, black (Figs 1A,B)

Nipponohelops 

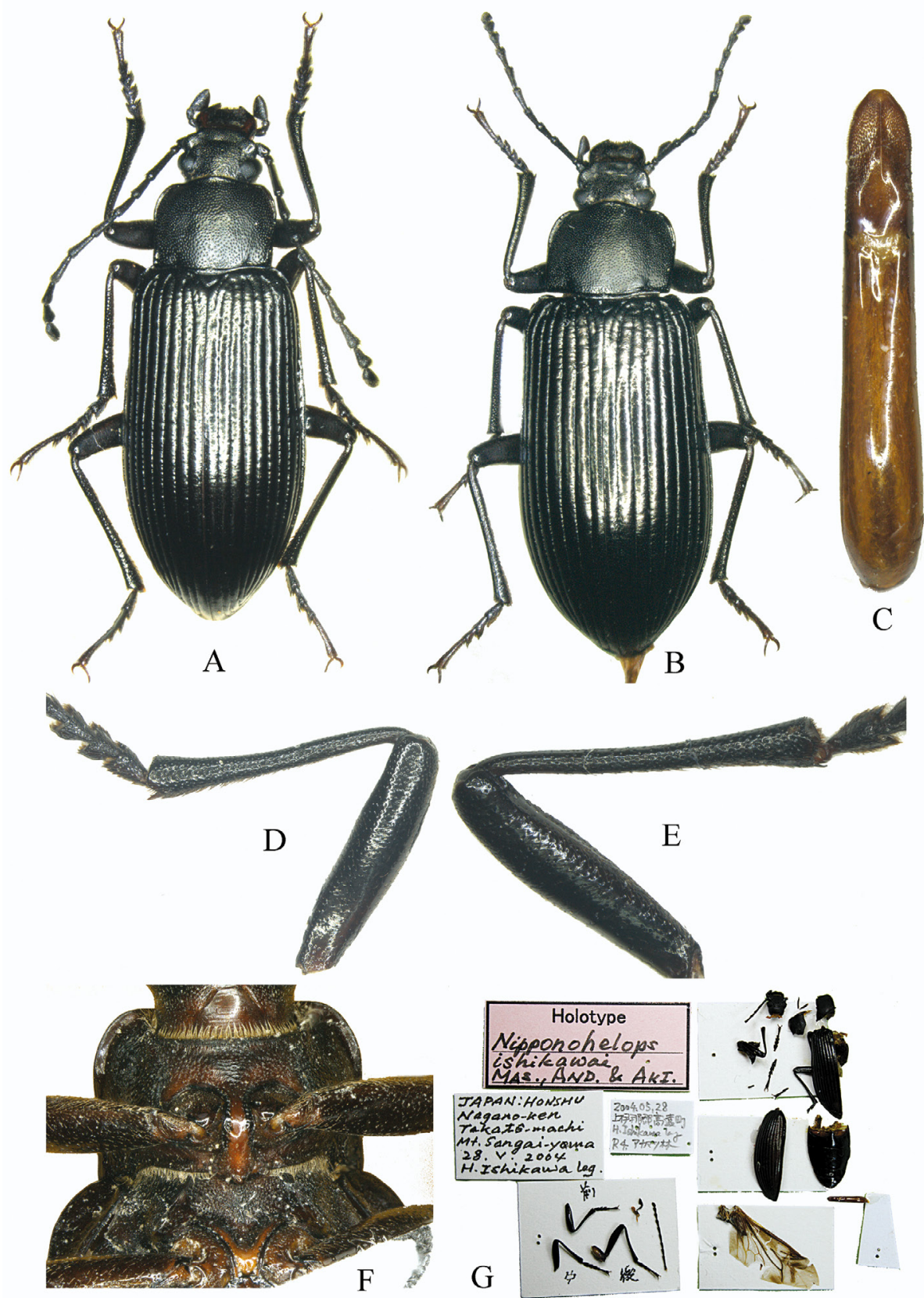

Fig. 1. Nipponohelops ishikawai: $\mathrm{A}=$ male, habitus, $\mathrm{B}=$ female, habitus, $\mathrm{C}=$ aedeagus, dorsal view, $\mathrm{D}=$ fore leg of male, $\mathrm{E}=$ middle leg of male, $\mathrm{F}=$ prothorax, ventral view, $\mathrm{G}=$ holotype and its labels 


\section{Nipponohelops Masumoto, Ando et Akita, 2006}

Type species Nipponohelops ishikawai Masumoto, Ando et Akita, 2006, by original designation. Masumoto et al., 2006: 33; Nabozhenko \& Löbl, 2008: 253.

The detailed species description was given in the description of the genus.

\section{Nipponohelops ishikawai Masumoto, Ando et Akita, 2006}

(Fig. 1)

Masumoto et al., 2006: 33, figs 1-9; Nabozhenko \& Löbl, 2008: 253.

Type material examined. Holotype: $\delta$ (NMNS) (separated specimen, placed on 5 plates) with labels: "Holotype Nipponohelops ishikawai Ms., And. \& Aki.", "Japan, Honshu, Nagano-ken, Takatô-machi, Mt. Sangai-yama, 28.V.2004, H. Ishikawa leg.”, “2004.05.28 上 伊那郡高遠町 H. Ishikawa leg. R4. アカマツ林”.

Material examined. 1 ô (CKA), Mt. Mitsugai-san, Takatô, Ina City, Nagano, 15.V.2010 (leg. Kiyoshi Ando).

Distribution. Japan: Honshu (Central districts).

\section{Apterotarpela Kaszab, 1954}

Type species Apterotarpela klapperichi Kaszab, 1954, by monotypy.

Kaszab 1954: 262; Nabozhenko \& Löbl, 2008: 247.

General morphology of adults. Body usually slender, strongly shiny, without or with weak metallic shade (Figs 3A-C). Head punctured by elongate punctures dorsally, with large convex eyes. Mentum without strong elevation at middle. Pronotum transverse; disc weakly depressed at each side near base, with elongate punctures; anterior angles not strongly projected. Prothoracic hypomera with fine dense wrinkles. Prosternal process weakly convex and weakly projected. Elytra with visible coeloconic sensilla in deep round small microfoveae, which are sometimes located in large tubercles on interstriae (Figs $3 \mathrm{~A}, \mathrm{C})$; striae with furrows or elongate not connected foveae; eighth interstria carinate or weakly elevated apically, connected with elytral edge; epipleura not reaching sutural angles. Winged or wingless. Winged species have humeral elevation near base of elytra (Figs 3B,C). Mesoventrite simple, not strongly depressed at middle; lateral margins of mesocoxal process not strongly elevated and laterally flattened. Abdominal ventrite 5 completely beaded along apical surface, pubescent apically. Male pro- and mesotarsi not widened.

Male genitalia and terminalia. Aedeagus 'helopioid'; apical piece acute apically; median lobe with widely rounded apex (Figs 4A-C). Inner sternite VIII weakly sclerotized, without additional sclerotized armature (Fig. 4E). Gastral spicula with straight branches, lobes without lateral teeth (Fig. 4D).

Female genital tubes. Spermatheca without basal duct, without short common duct basally and with multiple long branches (Fig. 4F).

Comments and comparison. KaszaB (1954) compared this genus with Asian Tarpela and distinguished Apterotarpela by the absence of wings. STEINER (2009) indicated (by citation of Horn 1870) that the American Tarpela species are fully winged, whereas the majority of Helops species are flightless. EsPAÑoL 
(1956) and recently Nabozhenko with co-authors (Keskin et al. 2017, NaboZHENKO et al. 2017) indicated that the presence, reduction or absence of hind wings in Helopini can be used as differential character only for species level. Comparative length of metaventrite, which relates with development of wings and often different even in closely related species. American Tarpela, Helops and Nautes are polyphyletic groups and the differential characters between these genera are not clear (Cifuentes-Ruiz et al. 2014). Species of all three genera would be fully winged, species of Neoarctic and Neotropic Helops have entire wings, reduced wings or wingless. The main and indistinct differences between Nautes-Tarpela and the New World Helops are in the structure of prosternal process and mesoventrite. Tarpela and Nautes Pascoe, 1876 have projected prosternal process and very deeply depressed mesoventrite with strongly elevate and flat or weakly convex lateral margins of mesocoxal process (Fig. 2D).

Apterotarpela can be compared with the New World Helops, from which it differs in the structure of eighth elytral interstriae connecting with elytral margin (American Helops and Tarpela have eighth interstria not connecting with elytral margin (Fig. 2F)), elytra with dorsal epipleural carina not reaching apex (but reaching eighth interstria) (Figs 3D, E) and surface of prothoracic hypomera with fine wrinkles, (not coarse punctures or deep and coarse not interrupted ribs as in the genera Helops, Tarpela (Fig. 2E) and Nautes). In addition, Apterotarpela differs from New World Tarpela in the structure of mesoventrite (see general morphology of Apterotarpela). See difference of Apterotarpela from Nipponohelops in the key.
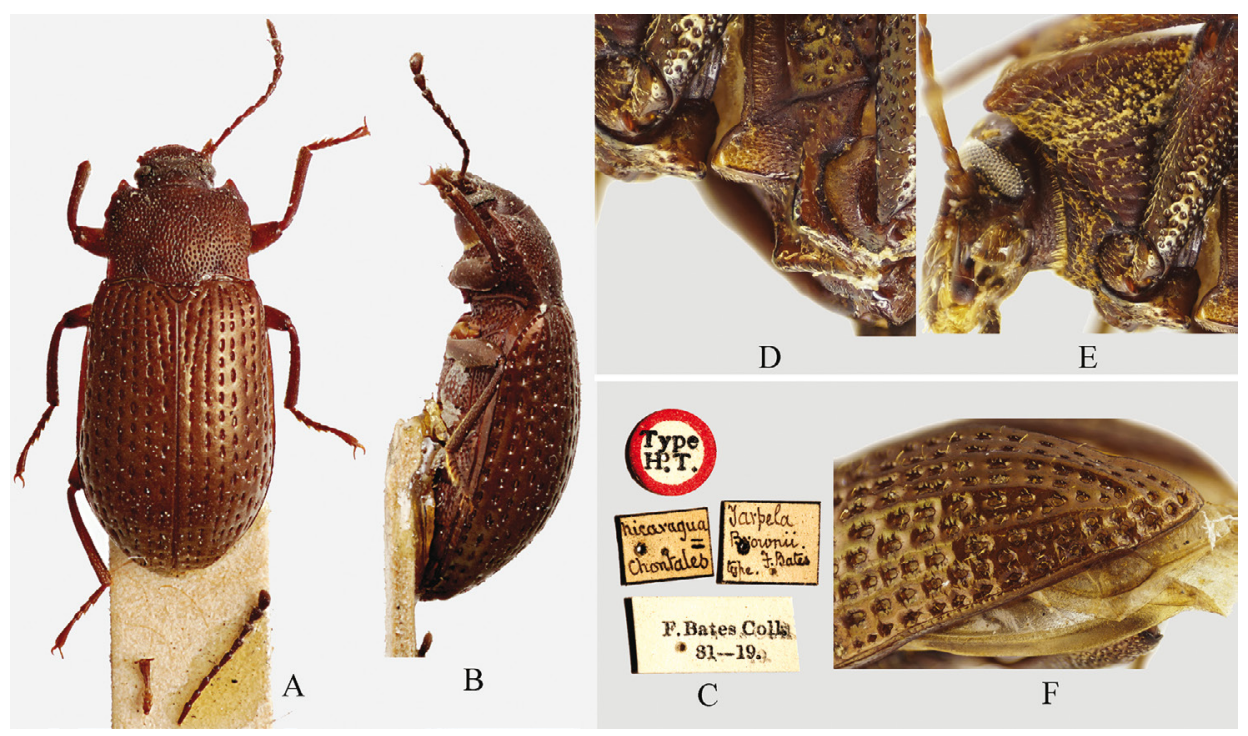

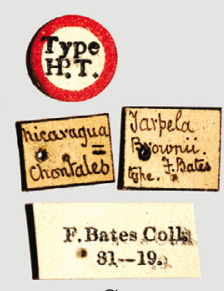

C

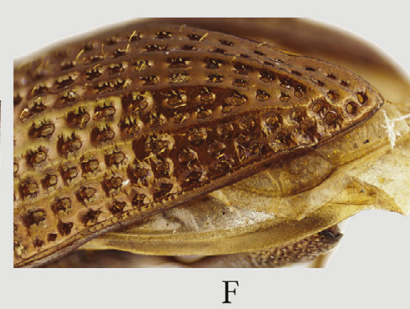

Fig. 2. New World species of the genus Tarpela: $\mathrm{A}=$ T. brownii Bates, holotype, dorsal vew, $\mathrm{B}=$ The same, lateral view, $\mathrm{C}=\mathrm{T}$. brownii, labels of the holotype, $\mathrm{D}=\mathrm{T}$. costata Champion, mesoventrite, ventro-lateral view, $\mathrm{E}=$ the same, hypomera and head, $\mathrm{F}=$ the same, apex of elytron 
Two Chinese species of Tarpela described by Kaszaв (1954), T. clypealis and T. subasperipennis, have all characters of Apterotarpela excluding presence of fully developed wings and must be transferred to this genus. All three species of Apterotarpela externally similar to Nalassus.

Comparative material examined: Tarpela brownii Bates, 1870 (Fig. 2A-C) (type species of the genus Tarpela), holotype (BNHM) with labels: "Type H.T." (circle), "nicaragua = Chontales", "Tarpela Brownii F. Bates type.”, “F. Bates Coll. 81-19"

Tarpela costata Champion, 1887 (Fig. 2D-F) (CN): 1 § , Mexico, Salcocotan, Nayant., 30.vii.1984 (leg. Barrera).

Distribution: The Eastern Palaearctic. China (Fujian).
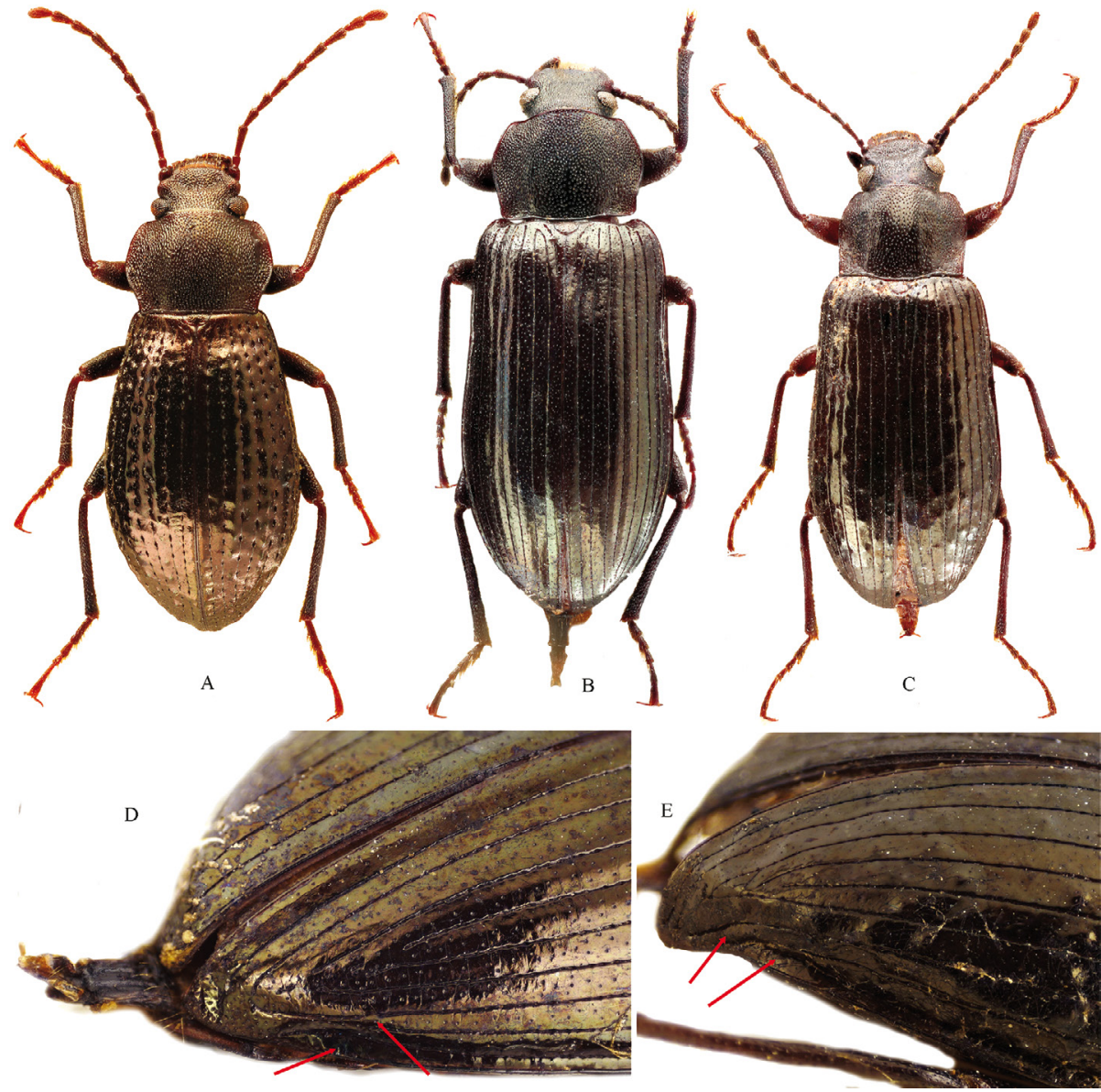

Fig. 3. The genus Apterotarpela: $\mathrm{A}=A$. klapperichi, habitus, $\mathrm{B}=$ A. clypealis, habitus, $\mathrm{C}=A$. subasperipennis, habitus, $\mathrm{D}=$ A clypealis, apices of elytra, $\mathrm{E}=A$. subasperipennis, apices of elytra 


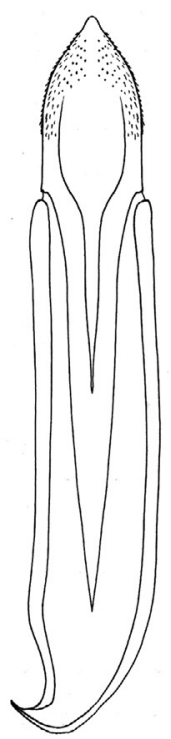

A

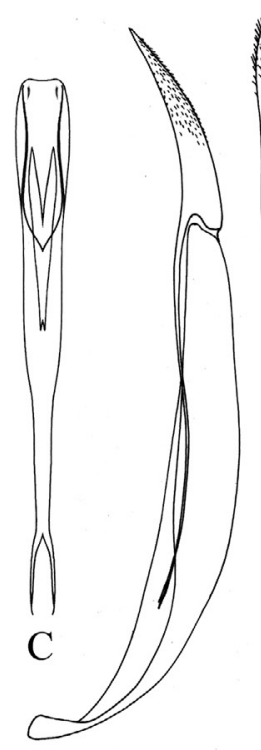

$\mathrm{B}$

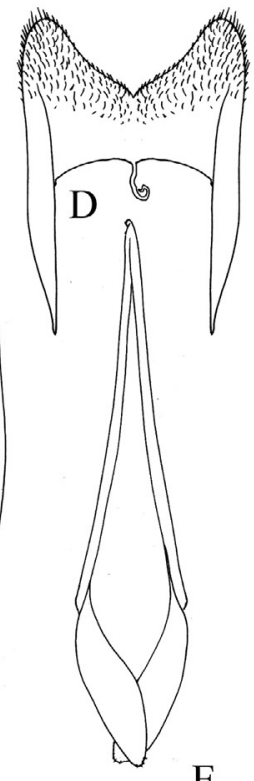

$\mathrm{E}$

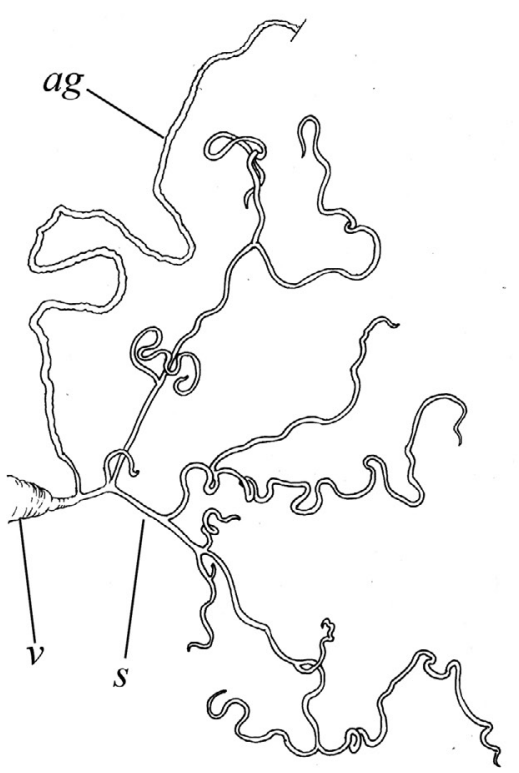

$\mathrm{F}$
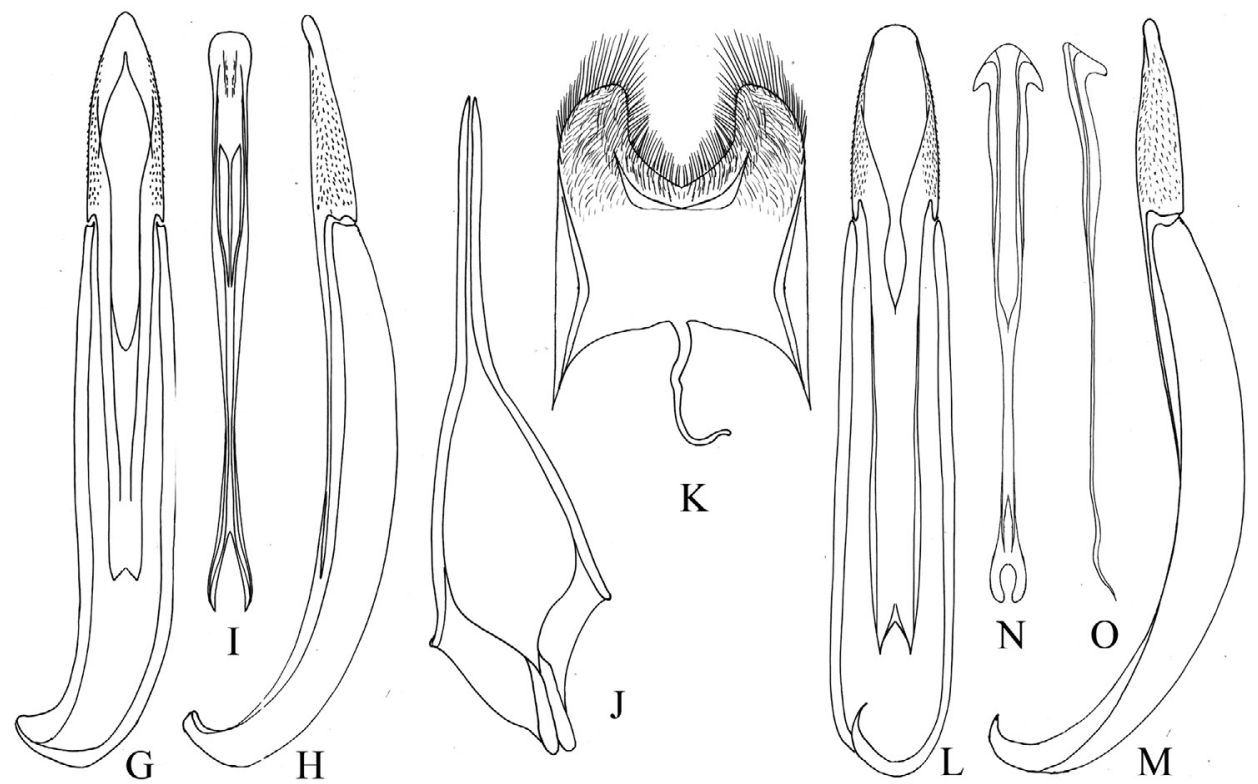

Fig. 4. Asiatic species of the subtrube Helopina (Tenebrionidae: Helopini), details of structure. Apterotarpela clypealis (A-F), Catomus solitarius (G-K), Stenohelops chinensis (L-O): A, $\mathrm{G}, \mathrm{L}=$ aedeagus, ventral view, $\mathrm{B}, \mathrm{H}, \mathrm{M}=$ aedeagus, lateral view, $\mathrm{C}, \mathrm{I}, \mathrm{N}, \mathrm{O}=$ median lobe of aedeagus (penis), $\mathrm{D}, \mathrm{K}=$ gastral spicula, $\mathrm{E}, \mathrm{J}=$ male inner sternite VIII, $\mathrm{F}=$ female genital tubes ( $a g$ - accessory gland of spermatheca, $v$ - vagina, $s$ - spermatheca) 

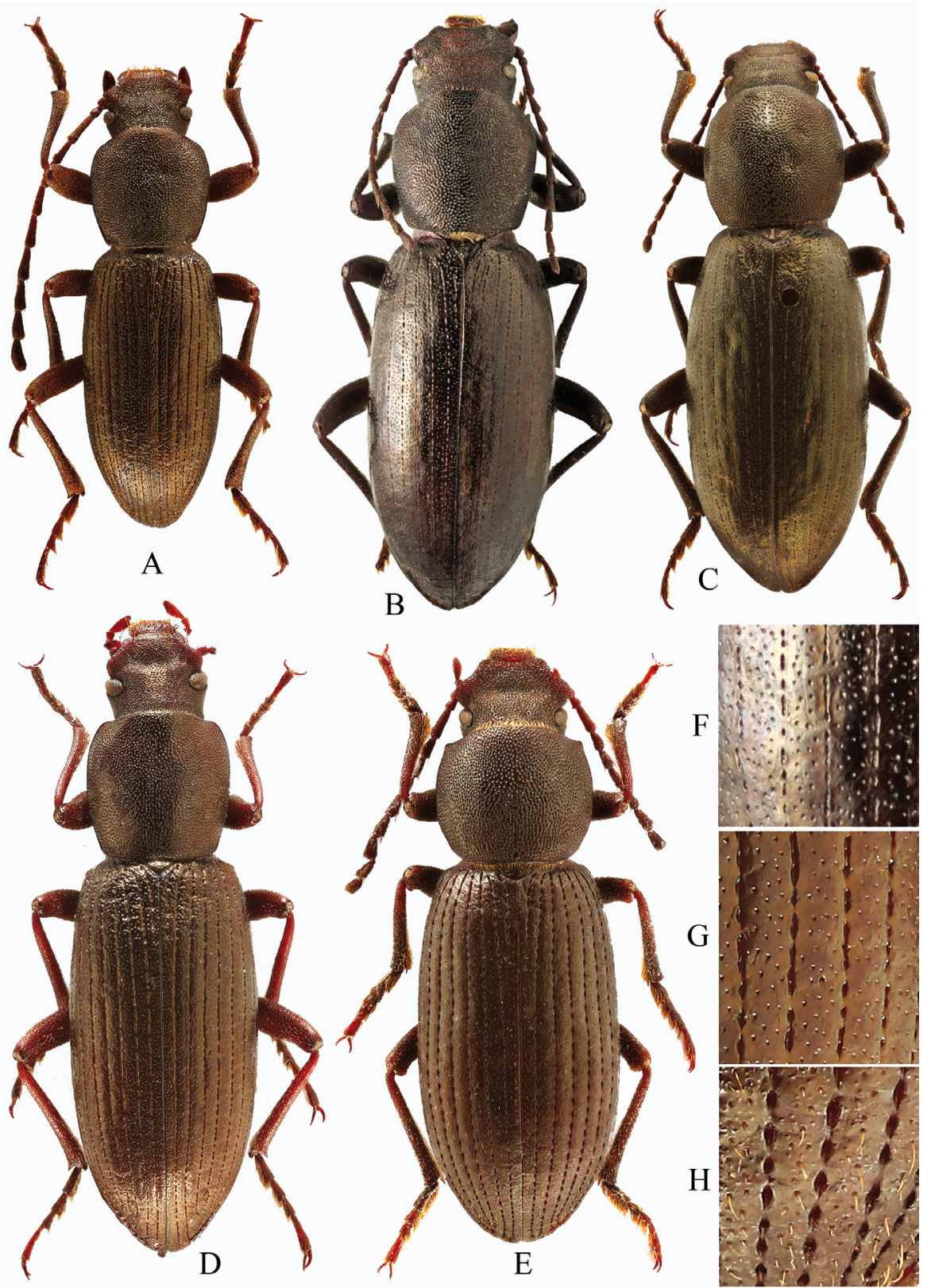

Fig. 5. Species of the genus Catomus, subgenus Sinocatomus. A = C. solitarius, male, Gansu (Wenxian), B $=$ C. solitarius, female from Sichuan (Venchuan), $C=C$. solitarius, holotype, Sichuan (Nanping), $\mathrm{D}=$ C. interruptus, female from Gansu (Wudu), E = C. stanislavi sp. n., holotype, female, Yunnan, $F=C$. solitarius, elytral intervals, female, $G=C$. interruptus, elytral intervals, female. $\mathrm{H}=$ C. stanislavi sp. n., elytral intervals, female 


\section{Apterotarpela klapperichi Kaszab, 1954}

(Fig. 3A)

Kaszab, 1954: 262; Nabozhenko \& Löbl, 2008: 247.

Type material examined. Paratype, $q$ (HNHM): “Kuatun (2300m) 27,40 n Br. 117.40ö

L. J. Klapperich. 22.3.1938 (Fukien)", "Paratypus 1954 Apterotarpela Klapperichi Kaszab"

Distribution. China (Fujian).

Apterotarpela clypealis (Kaszab, 1954), comb. nov. (Figs 3B, D; 4A-F)

Kaszab, 1954: 260 (Tarpela); Nabozhenko \& Löbl, 2008: 256 (Tarpela).

Material examined. 1 ^ , 1 + (HNHM): China, Fukien, Kuatun, 20-26.v.1946. leg. Tsung-sen / clypealis Kasz. det. Kaszab.

Distribution. China (Fujian).

Apterotarpela subasperipennis (Kaszab, 1954), comb. nov. (Figs 3C, E)

Kaszab, 1954: 261 (Tarpela); Nabozhenko \& Löbl, 2008: 257 (Tarpela).

Type material examined. Paratypes, ㅇ (HNHM): “Kuatun, Fukien China 22.10.46 (Tschung-sen)", "Paratypus 1954 Tarpela subasperipennis Kaszab".

Distribution: China (Fujian).

Key to Palaearctic species of the genus Apterotarpela

1 Anterior margin of frontoclypeus widely emarginate. Elytral intervals without tubercles (Fig. 3B), coeloconic sensilla located on flattened surface of interstriae

A. clypealis

- Anterior margin of frontoclypeus straight. Elytral intervals bearing tubercles with coeloconic sensilla (Figs 3A,C)

2 Elytral interval VIII strongly convex, keel-shaped. Elytra with rounded lateral margins. Wings strongly reduced

A. klapperichi

- Elytral interval VIII flat. Elytra parallel-sided. Fully winged

A. subasperipennis

Catomus Allard, 1876

Type species Catomus persicus Allard, 1876, by subsequent designation (Gebien, 1943). 
The Asian species of the genus were partly revised by NABOzHENKo (2006, $2007,2015 a)$ with detailed descriptions and diagnoses of subgenera. Only two species of the subgenus Sinocatomus Nabozhenko, 2006 are known from Sichuan Province of China (Nabozhenko 2006, Liu \& Ren 2010). This subgenus differs from other subgenera of Catomus by having the strongly convex keelshaped eight interstria near apex.

\section{Subgenus Sinocatomus Nabozhenko, 2006}

Type species Catomus solitarius Nabozhenko, 2006, by original designation.

$$
\begin{gathered}
\text { Catomus (Sinocatomus) solitarius Nabozhenko, } 2006 \\
\text { (Figs 4G-K; 5A-C, F) }
\end{gathered}
$$

Nabozhenko, 2006: 852; Nabozhenko \& Löbl, 2008: 249.

Type material examined: Holotype, $q$ (ZIN): China, North Sichuan, Nanping, 19.vi.2002 (leg. I. V. Shokhin).

Material examined. 1 ( $(\mathrm{SNMS})$ : China, S. Gansu, Wenxian, 32 ${ }^{\circ} 58^{\prime} \mathrm{N}, 107^{\circ} 46^{\prime} \mathrm{E}, 31 . \mathrm{v} .-$ 2.vi.1996 (leg. V. Beneš \& Štěpař); 1 ㅇ (SNMS): China, Centr. Sichuan, near Venchuan, 27-29.v.1995 (leg. V. Beneš).

Distribution. China (Sichuan, Gansu).

\section{Catomus (Sinocatomus) interruptus Liu et Ren, 2010}

$$
\text { (Fig. 5D, G) }
$$

Liu \& Ren, 2010: 71.

Material examined. 1 q (CSB): China, Gansu, Wudu, 2-7.vi.1996 (leg. E. Kučera). Distribution. China (Gansu).

\section{Catomus (Sinocatomus) stanislavi sp. $n$.} (Figs 5E, H)

Type material: Holotype, ㅇ (CSB): China, Yunnan, Daju, 7-10.vi.1995 (leg. E. Kučera).

Description. Body elongate, cylindrical, brown, without bronze shade. Head and pronotum moderately shiny, elytra matt. Head widest at genal level, covered with short recumbent hairs, widely deeply emarginate at anterior margin, elevated at genae and lateral margins of frontoclypeus; frontoclypeus depressed on surface; eyes oblique, transverse, convex; lateral margins with deep rounded emargination between genae and frontoclypeus; genae strongly protrudent, rounded; temples coarsely and sparsely punctured; vertex with very coarse punctation along laryngeal emargination and with coarse transverse wrinkles in gular area; ratio of the width at eyes to distance between eyes 1.34; ratio at the genal level to interocular distanse at eye level 1.06; punctation very coarse and dense, 
punctures round, connected with each other. Mentum, cardo and stipes with dense pubescence. Antennae short, with two distal antennomeres extended beyond base of pronotum; antennomere XI shorter than X, trapezoidal.

Pronotum transverse (1.17 times as wide as long), widest at middle, with base narrower than anterior margin, 1.36 times as wide as head; lateral margins moderately rounded, weakly sinuate near anterior angles; anterior margin widely rounded, widely sinuate near anterior angles; base evenly rounded; anterior angles projected, acute, posterior angles not expressed; all margins finely beaded; the bead of anterior margin not clear at middle; disc strongly evenly convex; punctures coarse and dense, weakly longitudinal, rounded near margins, and merged in anterior half of disc. Prothoracic hypomera with coarse transverse wrinkles. Prosternum before coxae with coarse and dense foveae; prosternal process broadened to apex, weakly convex.

Scutellum transverse, evenly rounded. Elytra elongate (1.90 times as long as wide), widest at middle, 1.70 times as wide as head, 1.27 times as wide as and 2.87 times as long as pronotum, covered with suberect short hairs; strial punctures deep, large, lanceolate, connected by fine furrows; inerstriae very weakly convex with fine and sparse rasp-shaped punctation.

Mesoventrite devoid of V-shaped depression, with very coarse and dense punctation. Mes- and metepisterna and metaventrite with coarse and sparse punctation. Abdominal ventrite 1 with coarse and sparse punctation (diameter of puncture subequal to interpuncture distance); ventrites 2-5 with denser punctation (diameter of puncture a little longer than interpuncture distance); ventrite 5 with wide bead and very coarse suberect hairs.

Legs slender; tibiae straight. Femora with subrecumbent hairs. Tibiae on inner side and tarsi on plantar surface with dense pubescence.

Body length $12.5 \mathrm{~mm}$, width $4.2 \mathrm{~mm}$.

Etymology. The new species is named in honour of Mr Stanislav Bečvář (Prague, Czech Republic), who provided us an interesting material from his nice collection of Tenebrionidae.

Differential diagnosis. See in the key to the species.

\section{Key to species of the Eastern Palaearctic Catomus}

1. Anterior angles of pronotum projected and acute (Fig. 5E). Elytra with rasp-shaped punctures and suberect hairs (Fig. 5H) C. stanislavi sp. n.

- Anterior angles of pronotum not projected and widely rounded (Figs 5A-D). Elytra glabrous (Figs 5F,G)

2. Head widest at eye level (Fig. 5D). Abdominal ventrite 5 without dense hair brush apically, only with simple recumbent setae C. interruptus

- Head widest at eye and genal level, otherwise only at genal level (Figs $5 \mathrm{~A}-\mathrm{C})$. Abdominal ventrite 5 with dense brush of suberect hairs

C. solitarius 


\section{Stenohelops Reitter, 1922}

Type species: Isopedus plicatulus Kraatz, 1880, by subsequent designation (Gebien, 1943).

General morphology of adults. Body small or moderate in size (body length 3.5-11 $\mathrm{mm}$ ), slender, convex, brown or rarely black, shiny, sometimes with bronze shade. Eyes weakly transverse, oval or rarely almost round (subgenus Gunarellus Reitter, 1922). Anterior margin of frontoclypeus straight. Male antennae long, with 4-5 apical antennomeres extending beyond base of pronotum, male with elongate banana-shaped ultimate antennomere (Fig. 6A). Pronotum always more or less cordiform (Fig. 6). Prothoracic hypomera with transverse wrinkles (subgenus Stenomaleis Español, 1957), with punctures (Stenohelops s. str., Gunarellus) or with combined wrinkles and punctures (some Gunarellus, Stenomaleis). Prosternal process weakly convex, not protrudent. Base of elytra with clear vertical border (pronotum rest against this border) and rounded, produced humeral angles. Elytra convex; interstriae sometimes with small granules, eighth interstria neither convex nor keel-shaped, connected with II-III interstriae apically and not connected with elytral margin; epipleura not reaching elytral apex, regularly narrowed to elytral sutural angles, with dorsal carina usually invisible dorsally. Legs slender, male protarsi widened.

Male genitalia (Figs 4L-O). Aedeagus 'helopioid'; apical piece acute or rounded apically; median lobe with rounded bifurcate apex.

Female genital tubes. Spermatheca without basal duct, with short common duct basally and multiple branches.

Larvae unknown.

Composition. The genus contains 24 species (NABozhenko \& Löвl 2008, Naвоzнеnко 2016) and is divided into three subgenera: s. str., Stenomaleis and Gunarellus. Differences between these subgenera are not distinct. Gunarellus differs from other subgenera by not beaded elytral suture at apex (not clear character within genus) and usually pubescent head or all body dorsally. Stenomaleis differs from nominotypical subgenus in the wrinkled (punctured in Stenohelops s. str.) prohypomera, but this character is constantly variable (combined, with punctures and wrinkles or with only punctures or with only wrinkles) even in different populations of one species (NABOZHENKO \& KESKIN 2009). No clear differences are recognized between Iberian and Moroccan species of the genus Helopelius Reitter, 1922 and Stenohelops (NAвOzHENко 2015b). One Chinese species can be formally placed to the subgenus Stenomaleis based on wrinkled prohypomera.

Distribution. The genus has disjunctive range as Nalassus: the main exclave occurs in the West Mediterranean region, the Balkans, Turkey and the Caucasus. The small generic exclave with a single species $S$. chinensis sp. $\mathrm{n}$. is located in Southern China.

\section{Subgenus Stenomaleis Español, 1957}

Type species Stenohelops ardoini Español, 1957, by original designation. 


\section{Stenohelops (Stenomaleis) chinensis sp. $\mathrm{n}$.}

(Figs 4L-O; 6)

Type material. Holotype ( $\delta$ ) and one paratype ( $q$ ) (CSB): China, Sichuan Pr., Abazhou: Nanping: Jizhaigou, 2000 m, 8-13.vi.1991 (leg. C. Holzschuh).

Male. Body slender, shiny, brown, with weak bronze tinge. Head straight at anterior margin of frontoclypeus; lateral margins distinctly emarginate between genae and frontoclypeus; genae with lateral margin angulate, strongly rounded at middle; eyes large, convex, obliquely transverse, with projected lower side; punctures on head coarse and dense, round and connected with each other at middle of frons; vertex very coarsely and densely punctured; gular area with transverse wrinkles and recumbent short setae; ratio of the width at eye level to interocular distance 1.52; ratio of the width at eye level to genal
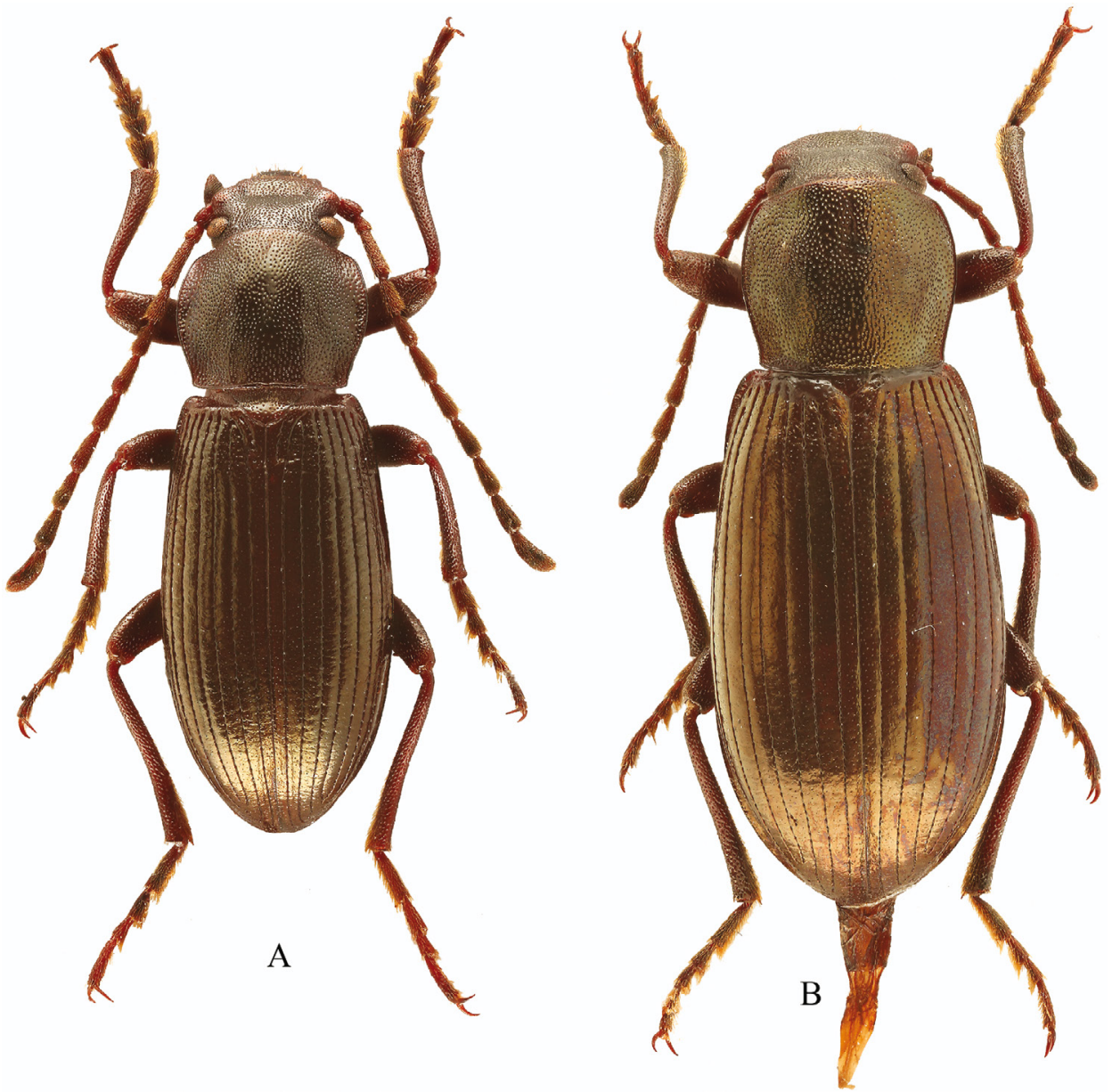

Fig. 6. Stenohelops chinensis sp.n., habitus: $A=$ male, holotype, $B=$ female, paratype 
level 1.09. Mentum with small longitudinal convexity in anterior part of middle. Antennae long, with five apical antennomeres extending beyond base of pronotum, reaching middle of elytra. Comparative length of antennomeres II-XI as following: $0.8: 2.8: 1.9: 1.8: 2.1$ : $2.1: 2.3: 2.1: 2.1: 2.6$; ultimate antennomere weakly banana-shaped.

Pronotum cordate, weakly transverse (1.16 times as wide as long), 1.4 times as wide as head; lateral margins weakly rounded, emarginate just before base; anterior margin widely weakly rounded; base also weakly rounded and sinuate at middle; all margins finely beaded except for middle of anterior margin; disc moderately convex, with flattened lateral sides, with punctures coarse and dense as on head, elongate on sides. Prosternum before procoxae with coarse and sparse punctures (diameter of the puncture subequal to interpuncture distance); prosternal process weakly convex, beaded. Prothoracic hypomera with longitudinal wrinkles.

Scutellum strongly transverse, with rounded margins. Elytra elongate, widest at middle, twice as long as pronotum, 1.68 times as wide as head, 1.2 times as wide as and 2.88 times as long as pronotum; strial punctures merged in entire deep furrows; interstriae convex, transversely wrinkled in basal two-thirds and flattened in apical third, with very fine and sparse punctures.

Mesepimera, mes- and metepisterna and metaventrite with coarse, moderately dense punctures, diameter of the puncture 1.5 times as long as interpuncture distance. Abdominal ventrites with coarse and dense punctures such as on metaventrite, but a little smaller. Abdominal ventrite 5 with recumbent hairs apically.

Legs slender; pro- and mesotibiae straight; metatibiae weakly curved. Protarsomeres I-IV moderately widened; mesotarsi weakly widened; metatarsi not widened.

Body length $8.4 \mathrm{~mm}$, width $3.0 \mathrm{~mm}$.

Female. Body with stronger bronze tinge. Antennae shorter, only four apical antennomeres extending beyond base of pronotum, reaching basal one-fourth of elytral length. Pronotum more convex, weakly flattened at sides. Elytra wider in base, with all interstriae flat. Tarsi not widened. Body length $10.9 \mathrm{~mm}$, width $4.2 \mathrm{~mm}$.

Etymology. Named after the country of China.

Differential diagnosis. This species differs from all known Stenohelops by flattened lateral sides of pronotal disc.

\section{Subtribe Cylindrinotina Español, 1956}

(Figs 7-26)

General differential morphology. Adult. Head with (Figs 14A, 18A) or rarely without posterior grooves (Figs 20A, 23A) or with deep wrinkle (Figs 8B, 16A) beginning at lower aspect of the eyes. Labrofrontoclypeal membrane always exposed. Abdominal ventrite 5 not beaded along outer margin in most of all taxa excluding Microdocnemis Nabozhenko et Keskin, 2010 (but often with finely beaded posterior end).

Male genitalia. Apical piece flattened laterally at apex (Figs 7B,F, 17B,G,L), with punctation, each puncture with very small seta directed toward the apex ('nalassoid' type of genitalia) or apical piece flattened dorso-ventrally at apex (Figs 7G), neither punctured nor setiferous ('cylindrinotoid' type of genitalia). Alae of apical piece moderately long, merged, concealed only half of median lobe, not reaching base of basal piece (Figs 7A,E,I,O, 17A,F,K). Basal piece separated from alae by connecting membrane only in apical half, with connecting membrane between margins in basal half. Median lobe acute 
apically, only with one apex, with weakly sclerotized baculi, which are not connected at base. Female genital tubes. Spermatheca composed of single long tube and short accessory gland (Figs 7M, 17P). Only the subgenus Caucasohelops Nabozhenko, 2006 of the genus Eustenomacidius Nabozhenko, 2006 has multibranched spermatheca (NAвоZнENко 2006). Valve between spermathecal and accessory gland ducts is absent.

Larva. Abdominal segment IX with small cylindrical or conical protuberances at base of urogomphi. Abdominal tergit VIII without protuberances.

\section{Key to genera of the subtribe Cylindrinotina of the Eastern Palaearctic region}

1. Prosternum punctured before procoxae (Figs 8C, 10F,H, 13F, 14A) or with smooth wrinkles and punctation (Fig. 11H). Prosternal process slightly convex in male and female, with not projected apex, and without teeth (Figs 8A,D, 10F,H, 11H, 13F, 14B). Male tibiae simple, without teeth (Figs 8A, 10C,D, 11D,E,F, 13C,D). Female procoxae not elevated at sides

Nalassus

- Prostenum with long transverse wrinkles before procoxae (Figs 18B, 19C, 20B,C, 21F, G, 22C, 23B, 24F, 25B, 26E). Male prosternal process strongly projected, tooth-shaped at apex with two strong teeth at sides (Figs 18C, 20C,D, 21F,G,I, 22C,D, 23C, 24H, 25B,C, 26E,F); male protibiae modified, ladle-shaped, curved and widened and flattened apically, often with one or two teeth before apex; mesotibiae sometimes with line of strong teeth on inner side (Figs 18G,H, 21C,D, 22E,F, 23D, 24B-D, 25D,E, 26B,C,D). Female prosternal process depressed at middle, without teeth (Figs 18E,F, 19C); tibiae not modified; procoxae with elevated sides near trochanters (Fig. 18F)

Asialassus gen. $\mathrm{n}$.

\section{Nalassus Mulsant, 1854}

(Figs 7-16)

Type species: Helops (Nalassus) dryadophilus Mulsant, 1854, by subsequent designation (Nabozhenko, 2001).

General morphology of adults. Body medial in size (length 5-12 mm), brown or rarely black, usually shiny, rarely with metallic luster, but sometimes dull, moderately flattened. Head with posterior grooves beginning at lower aspect of eyes. This character is, sometimes, not clear and head with posterior longitudinal depression instead of the grooves. East Asian species mainly without these grooves. Eyes moderately large or small (subgenus Caucasonotus Nabozhenko, 2001), not strongly transverse. Antennae of male often with weakly or strongly thickened in each antennomere, rarely (in Japanese and Taiwanese species) male and female antennomeres not thickened. Anterior margin of frontoclypeus straight (excluding deeply emarginate in N. melchiades (ReItTER, 1922)). 


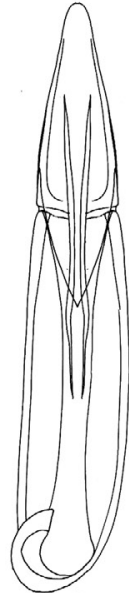

A

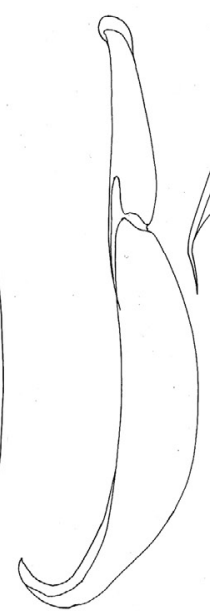

B

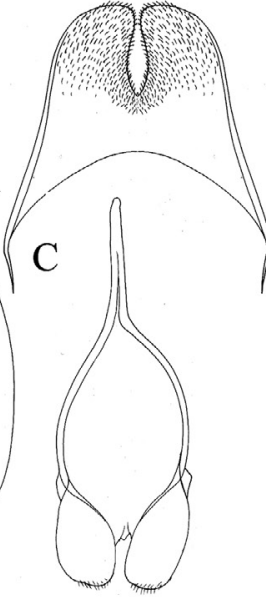

$\mathrm{D}$

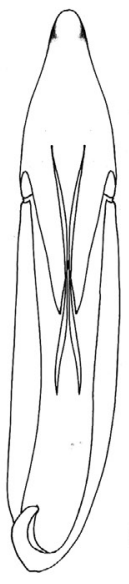

$\mathrm{E}$

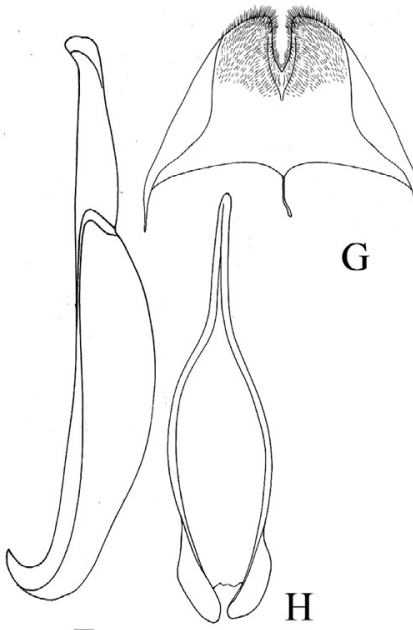

$\mathrm{F}$

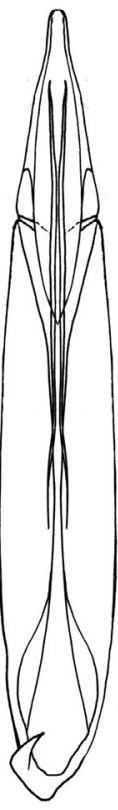

I
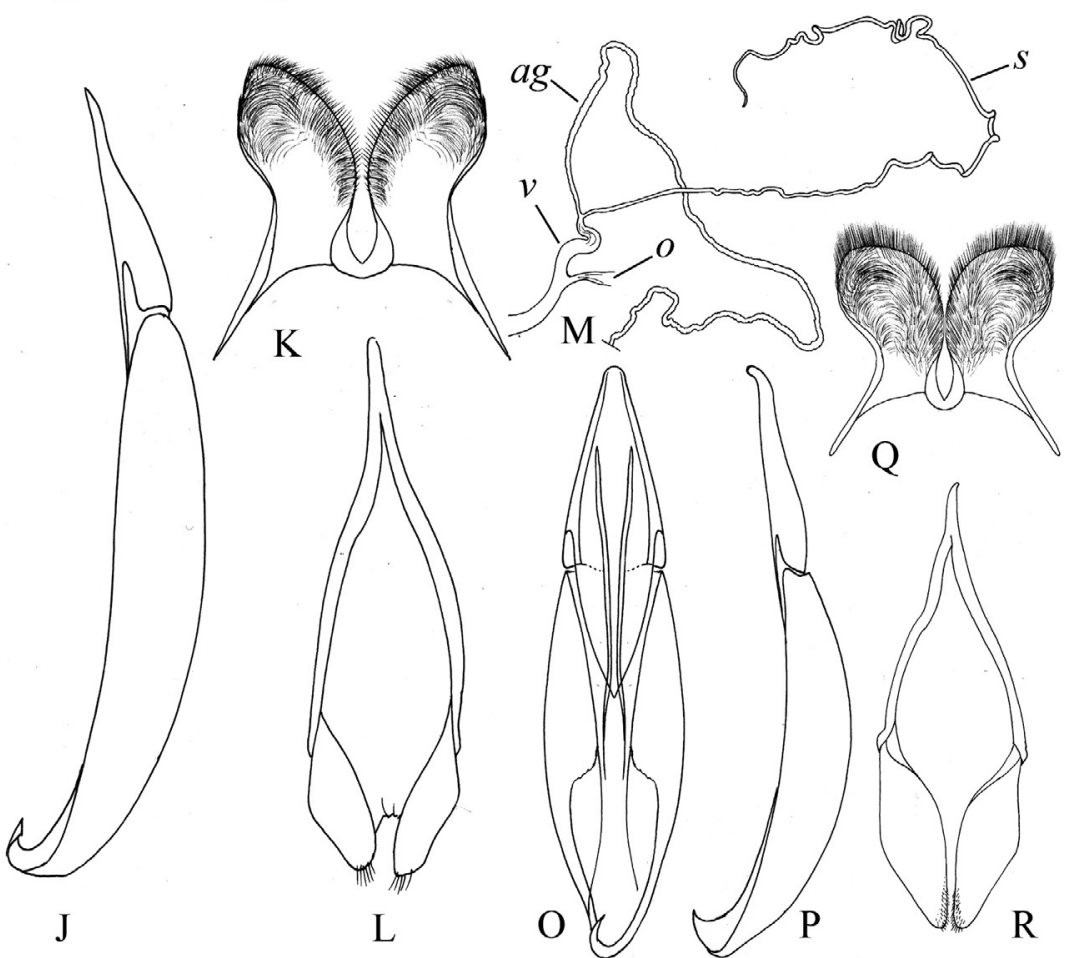

Q

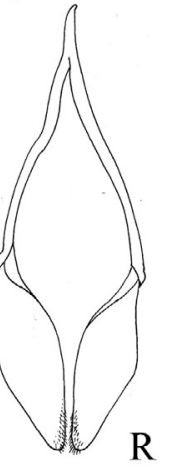

Fig. 7. The genus Nalassus, genital structure: N. (s. str.) pilushenmuus (A-D), N. (s. str.) zol$\operatorname{tani}(\mathrm{E}-\mathrm{H})$, N. (Nipponalassus) andoi (I-M), N. (Nipponalassus) lewisi (O-R): A, E, I, O = aedeagus, ventral view, B, F, J, P = aedeagus, lateral view, C, G, K, Q = male inner sternite VIII, $\mathrm{D}, \mathrm{H}, \mathrm{L}, \mathrm{R}=$ gastral spicula, $\mathrm{M}=$ female genital tubes $(a g-$ accessory gland of spermatheca,

$$
v \text { - vagina, } s \text { - spermatheca, } o \text { - oviduct) }
$$


Pronotum usually weakly convex. Prothoracic hypomera with longitudinal or irregular (Caucasonotus) wrinkles. Prosternum punctured, sometimes with smooth irregular wrinkles before procoxae. Prosternal process weakly convex, not projected apically, without teeth. Each elytron devoid of humeral callosity, with clear striae; punctures in striae normally confluent or connected (by furrow) with each other, often free from each other; interstriae with simple coeloconic sensilla, but without tubercles, eighth interstria apically more convex than other ones, connected with elytral margin; dorsal epipleural carina reaching eighth interval at apex; epipleura not reaching elytral apex and finished at level of abdominal ventrites 4 and 5 . Hind wings completely developed or absent. The most of species are flightless, but some Japanese and probably Taiwanese species can fly (observations of junior author, K. A). Mesoventrite slightly depressed at middle. Metaventrite transverse, glabrous or rarely densely pubescent (subgenus Nipponalassus subgen. n.). Male abdominal ventrites 1, 2 and sometimes 5 often with dense or sparse (Caucasonotus) hair brushes. Legs moderately slender, tibiae simple, without teeth, not flattened nor curved. Male tarsi not widened or protarsomeres II-III slightly widened. Trochanters with single long seta, rarely (Nipponalassus) with dense hair brush.

Aedeagus 'nalassoid' (Figs 7A-D, E-H) (subgenera Nalassus, Caucasonotus, Nipponalassus in part) or 'cylindrinotoid' (Fig. 7I, J) (subgenus Helopondrus Reitter, 1922, one species of Nipponalassus, one species of the nominotypical subgenus).

Female genital tubes (Fig. 7M). Spermatheca consists of only one non-branched tube (the most of all subgenera) or the tube with several very short branches at the base. Accessory gland short, a little longer than spermatheca or subequal to spermathecal length. Basal duct of spermatheca present or short.

Comments. The genus is divided into four subgenera: nominotypical, Helopondrus, Caucasonotus and Nipponalassus subgen. n. The subgenus Helopocerodes Reitter, 1922 was recently placed in the junior synonym of the nominotypical subgenus (KESKIN et al. 2017). Species of the subgenus Helopondrus have 'cylindrinotoid' male genitalia and female genital tubes but clearly belong to the genus Nalassus on larval morphology (NABOzHENko \& ARTokнiN 2017).

Composition. The genus contains recent species and subspecies: ten species and one subspecies in the Pacific Palaearctic region (China, Japan, Korean Peninsula, Taiwan, and the Russian Far East), three species in the Nearctic region (NAвоzHenko et al. 2016) and 68 species and subspecies in the Central and Western Palaearctic.

Key to the subgenera of the genus Nalassus

1. Abdominal ventrite 5 impressed at middle of apical half, emarginate at apex (Figs 13G, 14D, 16B,D). Trochanters with dense hair brushes (Figs $14 \mathrm{~B}-\mathrm{D}, 16 \mathrm{C})$. Male profemora with projected and flattened margin dorsally and pubescent inner anterior margin (Figs 13C,D, 16E,F); metaventrite and abdominal ventrites partly with dense pubescence (Figs 14D, 
16C,D). Male inner sternite VIII divergent at apex, very strongly and densely pubescent with long hairs (Figs 7K,Q)

Nipponalassus subgen. $n$.

- Abdominal ventrite 5 not impressed, with rounded apical margin. Trochanters with only one long sensillum (Fig. 8D, 10F,H, 11H). Male profemora simple (Figs 8A, 10E, 11G); metaventrite not pubescent. Male inner sternite VIII convergent at apex, with short, moderately dense hairs (Figs 7C,G)

2. Anterior angles of pronotum strongly projected, often with acute apex. Male abdominal ventrite 1 and sometimes 2 with coarse and sparse punctation of elongate punctures and sparse V-shaped hair brushes

Caucasonotus Nabozhenko, 2001

- Anterior angles of pronotum not projected, with widely rounded apex. Male abdominal ventrite 1 , sometimes 2 and 5 with fine and dense punctation of round punctures and dense oval hair brushes

3. Aedeagus 'cylindrinotoid', flattened dorso-ventrally, without suture between parameres and punctation. Spermatheca with very short branches in basal third. Pronotum usually with elongate punctures laterally. Male antennomeres not thickened

Helopondrus Reitter, 1922

- Aedeagus 'nalassoid', sparsely punctured, laterally with flattened keel at apex, and with apical suture between parameres; each puncture with very short seta directed apicad. Spermatheca without short branches. Pronotum with round punctures on sides. Male antennomeres often weakly to strongly thickened Nalassus (s. str.) Mulsant, 1854

Subgenus Nalassus Mulsant, 1854

Nalassus (Nalassus) brunneus brunneus (Marseul, 1876), comb. n.

(Fig. 8)

Marseul, 1876: 140 (Helops); Chûjô, 1975: 22 (Tarpela); Masumoto, 1993: 129, figs 1, 7 (Tarpela); Nabozhenko \& Löbl, 2008: 256 (Tarpela); Jung, 2012: 44, fig. 22 in plates II, V, X, XIII (Tarpela).

= Lamperos japonica Allard, 1876: 46 (Type locality: “Japon").

Material examined. $1 \hat{\jmath}$ (CKA): Japan, Kagoshima Pref., Yakushima, Malaise trap, 250 m, 1-30.xii.2007 (leg. Takeo Yamauchi et al.); 1 ઈ , 2 ㅇ (CKA): Japan, Ohkawa Rindô, Yakushima, Satsuma, 3.v.2008 (leg. Kiyoshi Ando); 3 exs. (CKA), Dazaifu, Fukuoka,

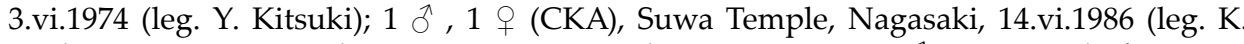
Ando); 1 ex. (CKA), Oshima, Kii, 29.iv.1959 (leg. Y. Kimura); 1 ô (CKA), Ashyû, Kyoto, 27.vi.1976 (leg. K. Ando); 3 exs. (CKA), Vill. of Four Seasons, Kyokushi, Kikuchi City, Kumamoto (Higo), 21.iii.2011 (leg. K. Ando); 2 exs. (CKA), ditto, 18.iii.2012 (leg. K. Ando); 
2 exs. (CKA), Yukawa, Nachikatsuura, Kii, 21.iii.1994 (leg. M. Yoshida); 1 (CKA), Mt. Tara-dake, Nagasaki, 3.v.2006 (leg. K. Ando); 3 exs. (CKA), Yosakoe-Pass, Kikawamura Vill., Tosa, 25.ix.1999 (leg. S. Nagashima); 2 ㅇ (CKA), Anbô, Yakushima, Satsuma, 6.v.2008 (leg. K. Ando); 2 exs. (CKA), Ohkawa Rindô, Yakushima, Satsuma, 3.v.2008 (leg. K. Ando); 1 ex. (CKA), Mt. Ukidake, Nanatsu Vill., Karatsu, Saga, 26.v.2007 (leg. K. Ando); 7 exs. (CKA), Japan, Kagoshima Pref., Hanyama, Yakushima Is., Malaise trap (H1 \& H2), 250 m alt., 1-30.xii.2007, 25-28.xii.2006, and 2-29.iii.2008 (leg. T. Yamauchi et al.); 4 exs. (CKA), Japan, Kagoshima Pref., Yakushima Is., Mt. Aiko-dake, Malaise trap (AN3), $170 \mathrm{~m}$ alt., 2-30.iii.2008 (leg. T. Yamauchi et al.); 1 ex. (CKA), Japan, Kagoshima Pref., Yakushima Is., Mt. Aiko-dake, Malaise trap (AC2), 150 m alt., 26-29.i.2007 (leg. T. Yamauchi et al.); 1 ex. (CKA), Japan, Kagoshima Pref., Yakushima Is., Kankakei, Malaise trap (K1), 220 m alt., 27.II.-2.iii.2007 (leg. T. Yamauchi et al.).

Distribution. Japan: Honshu (Southwestern districts), Shikoku, Kyushu, Izu-Ôshima Is., Nii-jima Is., Hachijô-jima Is., Hirado-jima Is., Tsushima Is., Yakushima Is.; Korea? The species was listed for Korea only by Heyden (1887) and probably by misidentification.
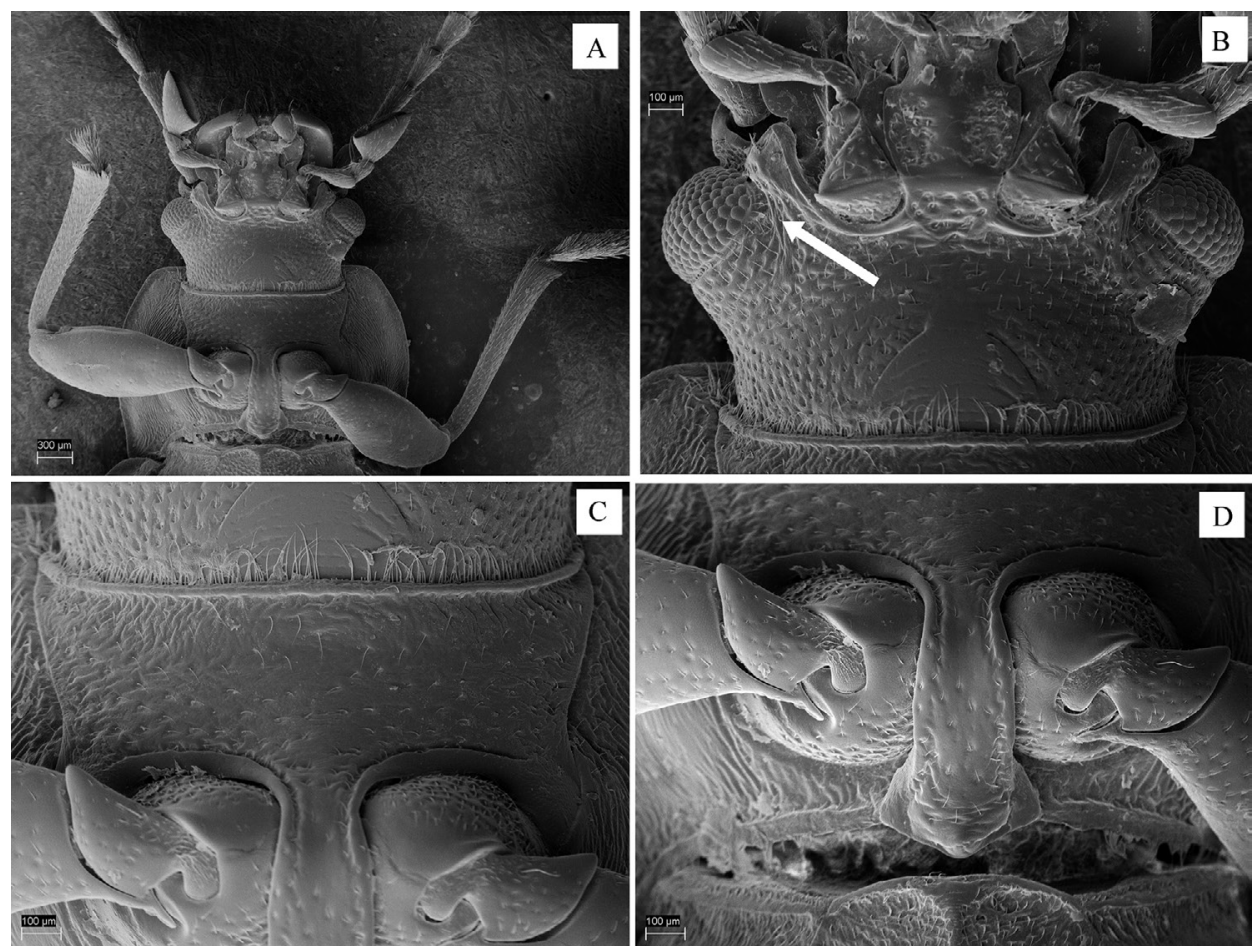

Fig. 8. Nalassus (s. str.) brunneus brunneus, details of structure: $\mathrm{A}=$ head and prothorax, ventral view, $\mathrm{B}=$ head, ventral view (arrow shows weakly developed posterior grooves beginning at lower aspect of eyes), $\mathrm{C}=$ prosternum, $\mathrm{D}=$ prosternal process, procoxae and protrochanters 
Nalassus (Nalassus) brunneus konoi (Nakane, 1963), comb. n.

(Fig. 9)

Nakane, 1963: 28 (Tarpela); Chûjô, 1977: 4; Chûjô, 1978a: 75 (Tarpela); Chûjô, 1978b: 15 (Tarpela); Masumoto, 1993: 129 (Tarpela); Nabozhenko \& Löbl, 2008: 256 (Tarpela).

Type material examined. Holotype (MHU), ô with labels: "Holotype", "Naka-noShima, Iss. Tokara, S. Japan, IV.3-13.1953. Coll. Hiroshi Kono”, “Tarpela brunnea konoi Nak. Det. T. Nakane. 1963”, “115-21b”, “Nakane Coll. SEHU Japan 1999”.

Material examined. 1 đ (CKA): Japan, Sokobaru, Ishigaki Is., Yaeyama, 20.i.2012 (leg. T. Nakata).

Comments. This subspecies was interpreted as the junior synonym of the nominotypical subspecies by Jung (2012) without any arguments. We consider N. brunneus konoi as a good subspecies (see differences in the key to the species).

Distribution. Japan: Tokara Nakanoshima Is., Amami-Ôshima Is., Okinawa-jima Is., Ishigaki-jima Is., and Iriomote-jima Is.
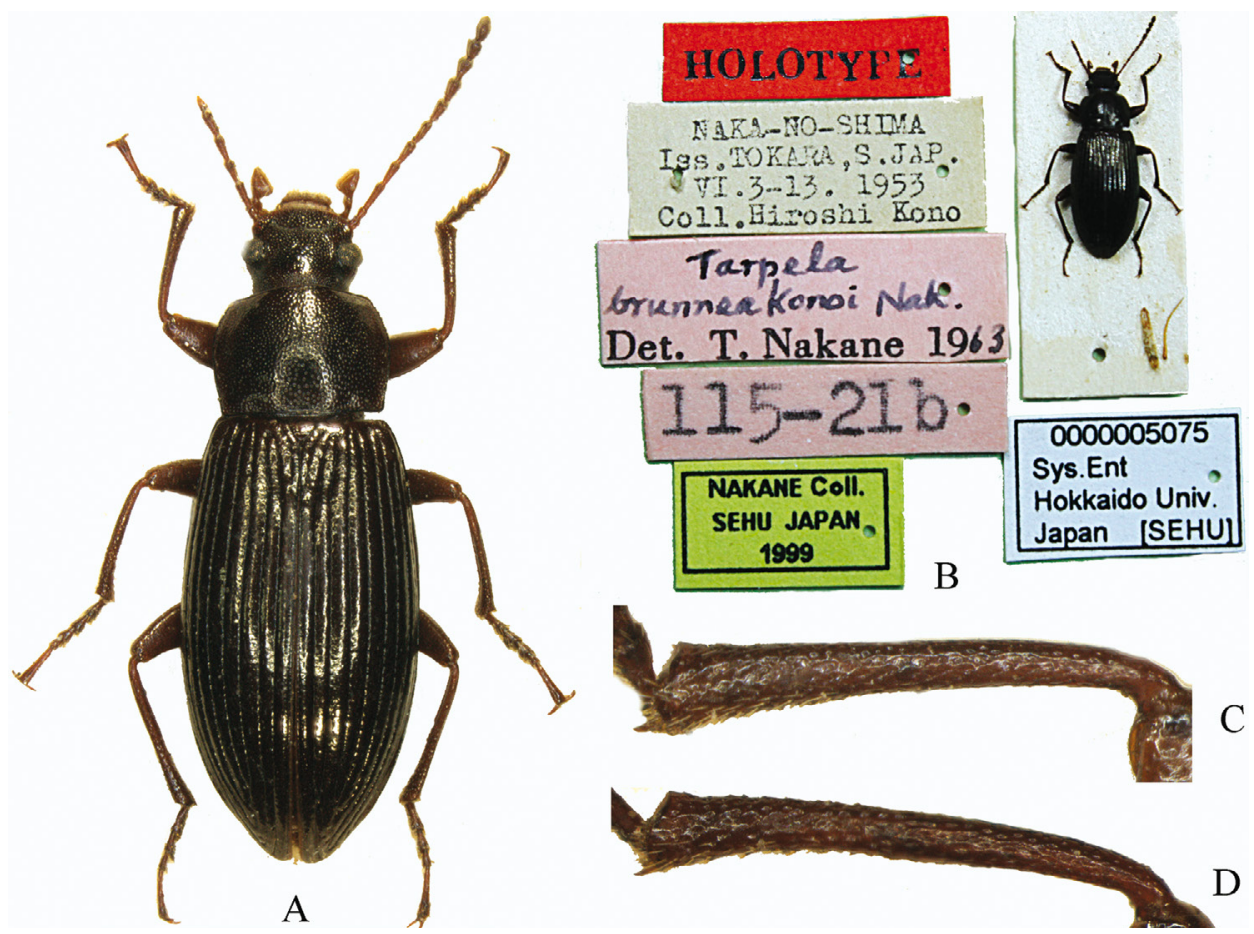

Fig. 9. Nalassus brunneus konoi, holotype, female: $\mathrm{A}=$ habitus, $\mathrm{B}=$ labels, $\mathrm{C}=$ protibia, $\mathrm{D}=$ mesotibia 


\section{Nalassus (Nalassus) pekinensis (Fairmaire, 1888)}

Fairmaire, 1888: 130 (Helops); Gebien, 1911: 549 (Helops); Gebien, 1943: 427 (806) (Cylindronotus insertae sedis); Nabozhenko \& Löbl, 2008: 241 (Cylindrinotus, insertae sedis); Nabozhenko, 2012: 35, figs 1, 2 (Nalassus (s. str.), new combination from Cylindrinotus).

Type material examined. Lectotype (designated by Naвоzнenко 2012), 9 (MNHP), with labels: "Pekin", "Helops pekinensis Fairm. Pekin", "Muséum Paris Coll. L. Fairmaire", "Syntype" (curator's label).

Distribution. China (Beijing).

\section{Nalassus (Nalassus) elegantulus (Lewis, 1894), comb. n.}

Lewis, 1894: 478 (Lamperos); Kim \& Kim, 1972: 79 (Tarpela); Kwon \& Choi, 1986: 109 (Tarpela); Chûjô \& Lee, 1993: 119 (Tarpela); Masumoto, 1993: 130, figs 2, 8 (Tarpela); Kim et al., 1994: 177 (Tarpela); Shin et al., 2000: 76 (Tarpela); Nabozhenko \& Löbl, 2008: 257 (Tarpela); Akita \& Masumoto, 2012: 279, figs 1, 13-16 (Tarpela); Jung, 2012: 46, fig. 24 in plates II, V, X, XIII; Ando et al., 2016: 72, fig. 40 (Tarpela).

Type material examined. Lectotype, ô (BNHM) with labels: "Lectotype" (circle), "Syntype" (circle), "Tarpela elegantula type $\widehat{\overbrace{}}$ Lewis", "Japan, G. Lewis, 1910--320" (designated by Маsuмото 1993).

Material examined. 1 † (CKA), Japan: Kanagawa, Zushi-shi, Junmu-ji, 18.iv.2012 (leg. Haruki Suenaga).

Distribution. Japan (Central Honshu); Taiwan? This species was recorded from Taiwan only by Gebien (1914: 40) from Kosempo and Koshun.

$$
\text { Nalassus (Nalassus) magyari (Kaszab, 1968) }
$$

Kaszab, 1968: 12 (Tarpela); Kwon \& Choi, 1986: 109 (Tarpela); Kim et al., 1994: 177 (Tarpela); Nabozhenko \& Löbl, 2008: 257 (Tarpela); Jung, 2012: 46, fig. 25 in pls. II, VI, X, IV, XVIII (Tarpela); Nabozhenko \& Ivanov, 2015: 137 (Nalassus (Helopocerodes)).

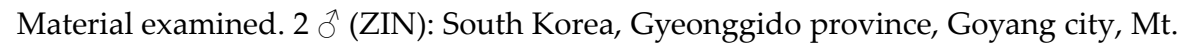
Bukhan, temple Heungguk, 31.iii.2006 (leg. Taewoo Kim).

Distribution. Korean Peninsula; Japan?

$$
\text { Nalassus (Nalassus) akitai (Masumoto, 1998), comb. n. }
$$

(Fig. 10)

Masumoto, 1998: 317, figs 10, 33-34 (Tarpela); Nabozhenko \& Löbl, 2008: 256 (Tarpela).

Type material examined. Holotype, ô (NMNS) with labels: "Holotype Tarpela akitai Masumoto", "Ryukyu: Iriomote Is. Maryûdo F. 22.XII.1995 Mas. Kimura", "Coll. Masumoto 2001". 


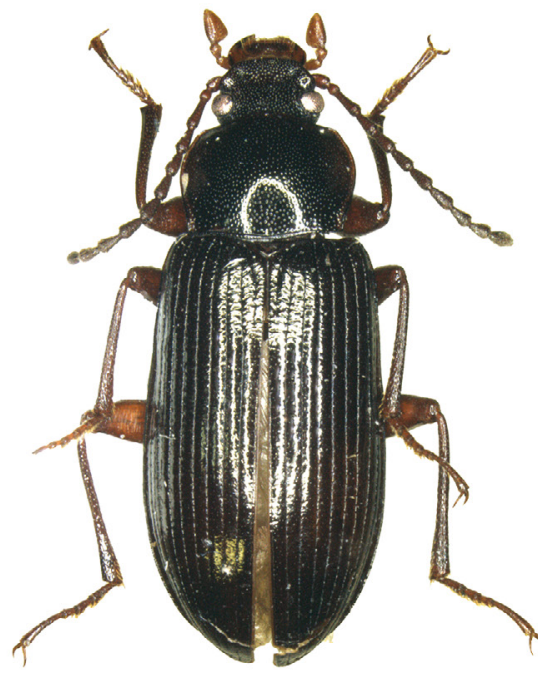

A
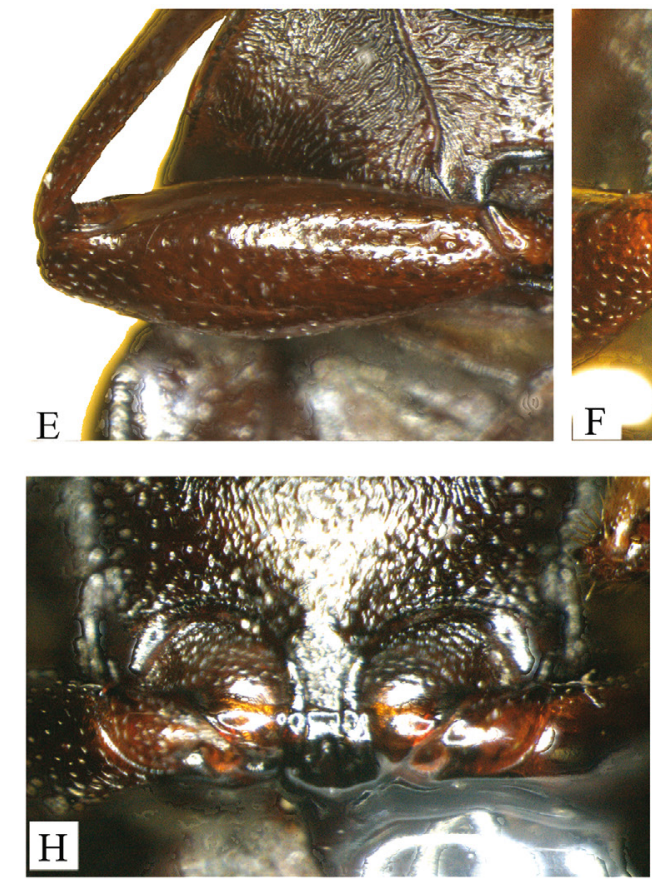

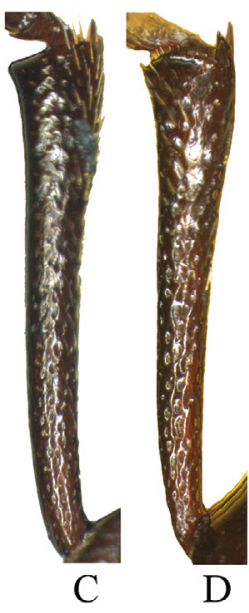

B

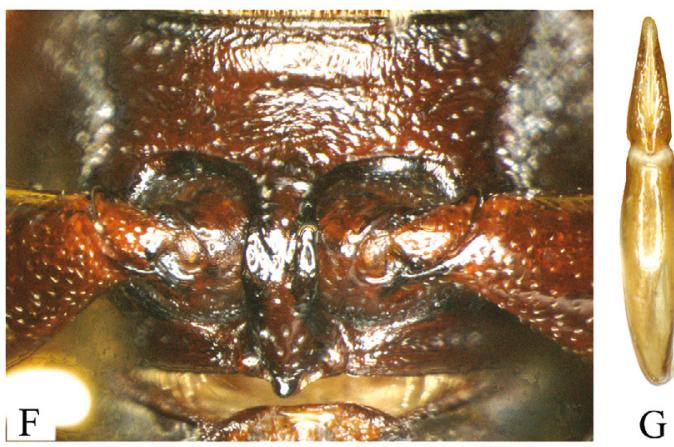

$\mathrm{G}$

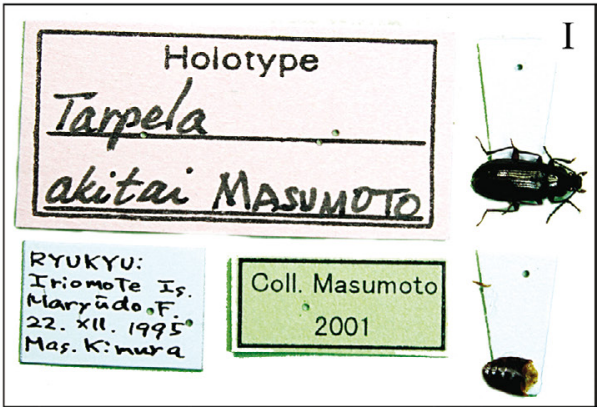

Fig. 10. Nalassus (s. str.) akitai, holotype and paratype: $\mathrm{A}=$ male, holotype, habitus, $\mathrm{B}=\mathrm{fe}-$ male paratype, habitus, $\mathrm{C}=$ male protibia, $\mathrm{D}=$ male mesotibia, $\mathrm{E}=$ male profemur, $\mathrm{F}=$ male prothorax, ventral view, $\mathrm{G}=$ aedeagus, dorsal view, $\mathrm{H}=$ female prothorax, ventral view, $\mathrm{I}=$ labels of the holotype 
Material examined. 5 ô, 2 ㅇ (CKA), Ishigakijima Is.: Sokobaru, Okinawa, 20.i.2012 (leg. T. Nakata); $1 \hat{\jmath}, 1$ (CKA), ditto, 14.i.2012 (leg. T. Nakata); 2 ㅇ (CKA), [Ryukyu] Mt. Omoto-dake, Ishigaki-shi, 17.iii.2000 (leg. T. Kurihara). jima Is.).

Distribution. Japan (Yaeyama islands: Iriomote-jima Is., Ishigaki-jima Is., Yonaguni-

\section{Nalassus (Nalassus) kawabatai (Akita et Masumoto, 2012), comb. n.} (Fig. 11)

Akita \& Masumoto, 2012: 276, figs 3-2, 7-20 (Tarpela).

Material examined. $1 \hat{\jmath}, 3$ + (CKA), Nakanogô, Hachijo Is., 1.v.1967 (leg. S. Tsuyuki); 1 q (CKA), Kurosaki-takaoyama, Mikurajima Is., 7.vi.1972, no Collectors data; 1 \& (CKA), Mikurajima Is., Izu islands, 28--30.v.2003 (leg. I. Tanaka); 1 ㅇ (CKA), Miyake Is., Tsubota,
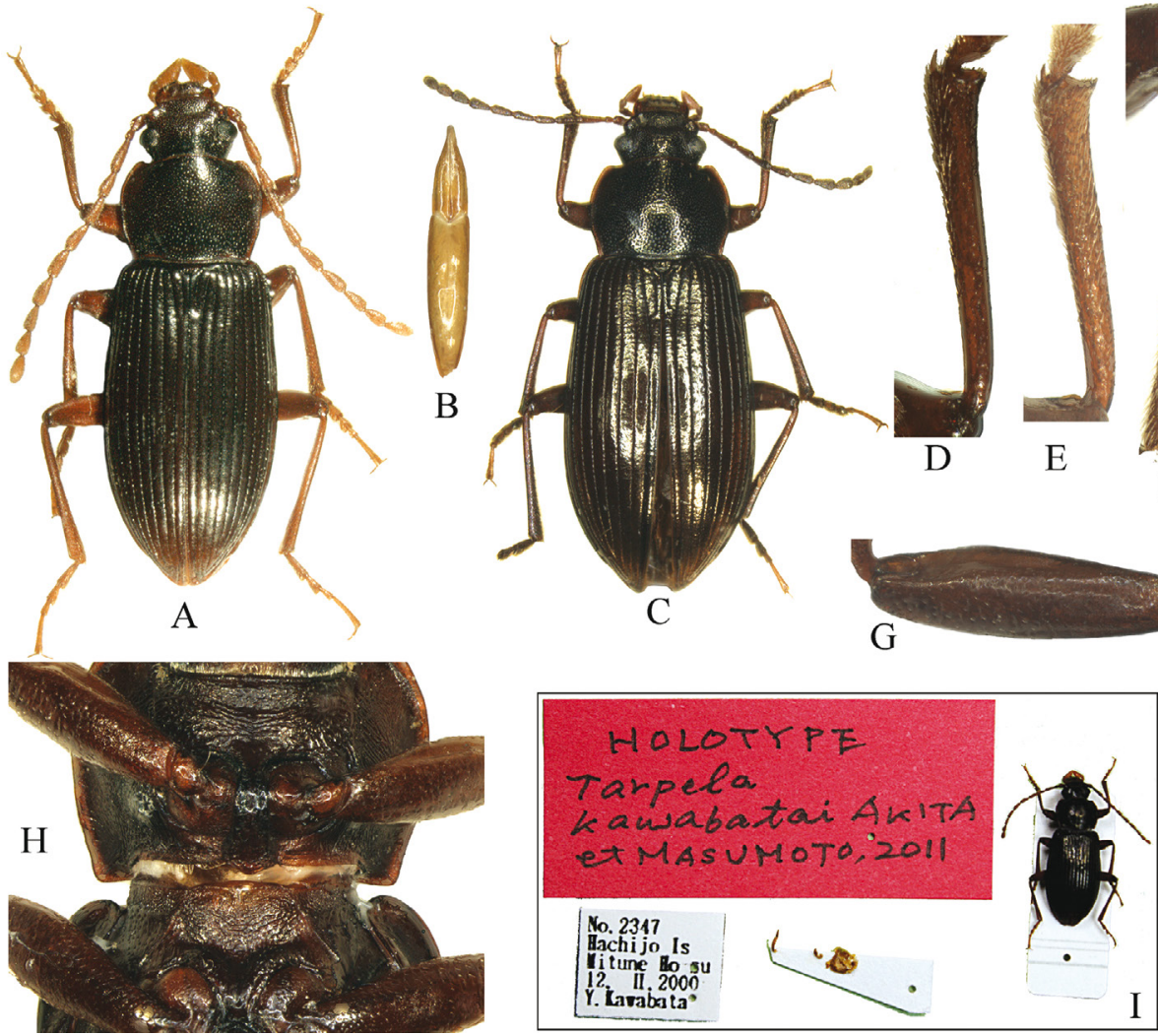

Fig. 11. Nalassus (s. str.) kawabatai, holotype and paratype. $\mathrm{A}=$ male, holotype, habitus, $\mathrm{B}=$ aedeagus, dorsal view, $\mathrm{C}=$ female paratype, habitus, $\mathrm{D}=$ male protibia, $\mathrm{E}=$ male mesotibia, $\mathrm{F}=$ male metatibia, $\mathrm{G}=$ male profemur, inner side, $\mathrm{H}=$ male prothorax, ventral view, $\mathrm{I}=$ labels of the holotype 
15viI.1971 (leg. M. Miyahara); 1 q (CKA), Oshima, Izu, Tokyo, $4 . v i i .1971$ (leg. M. Takakuwa).

Distribution. Japan: Izu Islands (Izu-Ôshima Is., Nii-jima Is., To-shima Is., Miyakejima Is., Mikura-jima Is., Hachijo-jima Is.).

\section{Nalassus (Nalassus) olgae Nabozhenko et Ivanov, 2015}

Nabozhenko \& Ivanov, 2015: 138, figs 1-12 (Nalassus (Helopocerodes)).

Type material examined. Holotype, $\hat{\sigma}(\mathrm{ZIN})$ and 42 paratypes $(21 \hat{\jmath}, 21 \uparrow)$ (ZIN and private collections of M. Nabozhenko and S. Ivanov) with label: "Russia, Primorsky kray, Oktyabrsky District, near Chernyatino, Sinelovka Mt., 17.05.-28.06.2014 (leg. S.N. Ivanov)".

Distribution. Russia (Far East, Primorsky kray).

\section{Nalassus (Nalassus) formosanus (Masumoto, 1981), comb. n.}

(Fig. 12A)

Masumoto, 1981: 35, photo 15 (Tarpela); Masumoto et Kondo, 1984: 23 (Tarpela); Nabozhenko \& Löbl, 2008: 257 (Tarpela); Ando et al., 2016: 24 (Tarpela); Masumoto et al., 2017: 2, figs 6, 18-19 (Tarpela).

Material examined. 1 ㅇ (EUM): Taiwan: Taichung, Mt. Anmashan, alt. ca. 2275 m, 3.vii.2005 (leg. Hisamatsu S-T.).

Distribution. Taiwan.

Notes. Masumoто et al. (2017) indicated that punctation of pronotum of this species is very dense, with sometimes connected elongate punctures. They studied the specimen from the same locality (Mt. Anmashan) in their series. The specimen examined by us has moderately dense punctation of round not connected punctures. Length of beetles from the type series are 7-13 mm (Masumoto 1981), and in the recent key are 10.5-16 $\mathrm{mm}$ in contrast with all other smaller species (Masumoтo et al. 2017, p. 10).

\section{Nalassus (Nalassus) zoltani (Masumoto, 1981), comb. n.}

(Fig. 12B)

Masumoto, 1981:34, photo 14 (Tarpela); Masumoto \& Kondo, 1984: 23; Nabozhenko \& Löbl, 2008: 257 (Tarpela); Ando et al., 2016: 24 (Tarpela); Masumoto et al., 2017: 2, fig. 7 (Tarpela).

Material examined. 2 ก (CKA): Taiwan, Iylan, Tatung Township, alt. $1950 \mathrm{~m}$, 30.iii.2004 (leg. T. Kurihara); 1 † (CKA): Taiwan, Chiai Hsien near Fenchifu, 10-11.iv.1995 (leg. H. Kojima)

Distribution. Taiwan. 
Notes. The male of this species has been unknown. In our examination, the male differs from female in the deeply depressed strial punctures in the basal half of elytra, and very fine not depressed punctures in the apical half; protarsomeres I-IV are weakly widened, longitudinal; antennae are longer (fourth apical antennomeres extending beyond the base of pronotum, antennae reaching basal third of elytra), and pronotum is narrower (1.3 times as wide as long).

Nalassus (Nalassus) pilushenmuus (Masumoto, Akita et Lee, 2017), comb. n. (Fig. 12C)

Masumoto et al., 2017: 2, figs 1, 8-9 (Tarpela pilushenmua).

Material examined. 1 đ (CKA): Taiwan, Iylan, Tatung Township, alt. 1950 m, 30.iii.2004 (leg. T. Kurihara).

Distribution. Taiwan.

Notes. Masumoto et al. (2017) indicated in the description that male pronotum in this species is 1.2 times as wide as long. These mesurements were used by the authors in the key: 9(10) " $\ldots$ width/length $=$ ca $1.20\left(\delta^{\lambda}\right)^{\prime \prime}$ and 10(9) “...
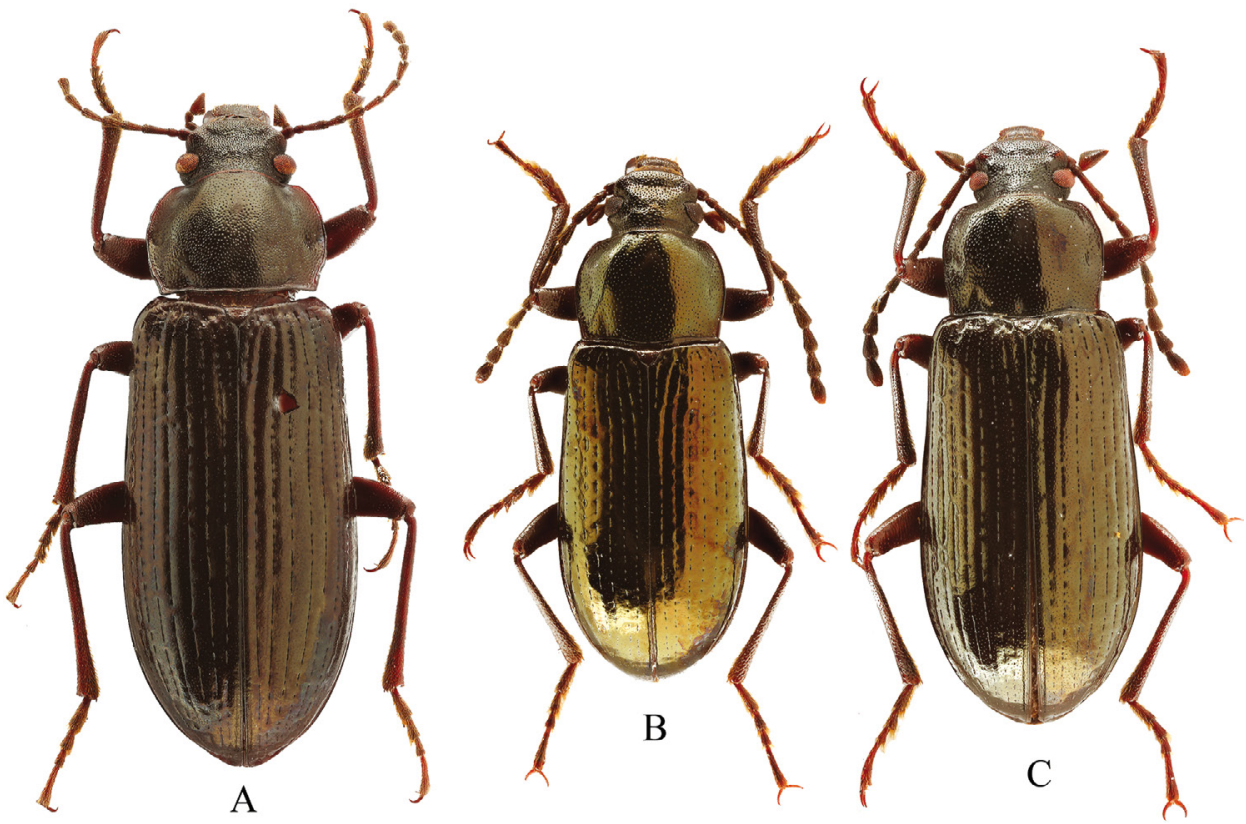

Fig. 12. Nalassus (s. str.) from Taiwan, habitus. $\mathrm{A}=$ N. formosanus, female, $\mathrm{B}=$ N. zoltani, male, $\mathrm{C}=\mathrm{N}$. pilushenmuus, male 
width/length $=1.25-1.50(\delta)$ ". Measurements of pronotum on the photo of the holotype (Masumoto et al., 2017, fig. 1) clearly show that the pronotum is 1.28 times as wide as long. Our specimen has pronotum 1.27 times as wide as long. As a result, this character is not suitable for identification. It has much more distinct differential character such as external morphology of male protarsi, which are not widened in Nalassus pilushenmuus and distinctly widened in compared species N. xiaoxueshanus (Masumoto, Akita and Lee, 2017) and N. dongurii (Masumoto, Akita and Lee, 2017) (see Masumoto et al. 2017: figs 1, 3, 4).

Nalassus (Nalassus) yuanfengus (Masumoto, Akita et Lee, 2017), comb. n. Masumoto et al., 2017: 4, figs 2, 10-11 (Tarpela yuanfenga).

Distribution. Taiwan.

Note. This species clearly belongs to the genus Nalassus based on the description, figures of male genitalia and the photograph of the holotype.

Nalassus (Nalassus) xiaoxueshanus (Masumoto, Akita et Lee, 2017), comb. n. Masumoto et al., 2017: 6, figs 3, 12-13 (Tarpela xiaoxueshana).

Distribution. Taiwan.

Note. This species clearly belongs to the genus Nalassus based on the description, figures of male genitalia and the photograph of the holotype.

Nalassus (Nalassus) dongurii (Masumoto, Akita et Lee, 2017), comb. n. Masumoto et al., 2017: 6, figs 4, 14-15 (Tarpela).

Distribution. Taiwan.

Note. This species clearly belongs to the genus Nalassus based on the description, figures of male genitalia and the photograph of the holotype.

Nalassus (Nalassus) merkli (Masumoto, Akita et Lee, 2017), comb. n. Masumoto et al., 2017: 9, figs 5, 16-17 (Tarpela).

Distribution. Taiwan.

Note. This species clearly belongs to the genus Nalassus based on the description, figures of male genitalia and the photograph of the holotype. 
Key to the species of the nominotypical subgenus of the genus Nalassus of Eastern Palaearctic

(without Taiwan; for Taiwanese species see newest key in Masumoтo et al. (2017))

1. Outer apex of protrochanters acute, elevate above femoral level (Fig. 8D)

N. brunneus

- Outer apex of protrochanters rounded, not elevate above femoral level (Fig. 10H)

2. Elytra subparallel at sides. Male mesotibiae straight N. brunneus brunneus

- $\quad$ Elytra elongate-oval (Fig. 9A). Male mesotibiae curved (Fig. 9D)

N. brunneus konoi

3. Elytral interstriae with punctures coarse and dense, subequal in width to distance between them.

- Elytral interstriae with fine and sparse punctures, whose interpuncture distance 2-4 times as wide as a diameter of puncture)

4. Elytral striae consist of round punctures connected by furrows. Abdominal ventrite 5 not beaded apically

N. pekinensis

- Elytral striae consist of only deep furrows. Abdominal ventrite 5 completely beaded

5. Male metaventrite convex in anterior half, with smooth tubercle, and with T-shaped deep depression near base. Female metaventrite with weak convexity, divided by arcuate transverse wrinkles

N. olgae

- Metaventrite in both sexes without convexity, tubercle and transverse wrinkles

N. magyari

6. Body completely dull dorsally. Pronotum without two oblique deep or weak impressions near base

N. elegantulus

- Body shiny dorsally at least head and pronotum. Pronotum often with two oblique deep or weak impressions near base

7. Male antennae slightly thicker than those in female, strongly elongate, with five distal antennomeres extended beyond base of pronotum, reaching middle of elytra. Pronotum in both sexes not cordate N. kawabatai

- Male antennae not thicker than in female, shorter, with three distal antennomeres extended beyond base of pronotum, reaching basal third or basal fourth of elytra. Pronotum in both sexes distinctly cordate

N. akitai 
Subgenus Nipponalassus subgen. $n$.

(Figs 13-16)

Type species: Tarpela andoi Masumoto, 1993

Diagnosis. Body slender, shiny, brown. Head with posterior grooves (Fig. 14A) or with single deep wrinkle (Fig. 16A) beginning at lower aspect of eyes. Eyes large, close with each other dorsally. Male antennae thin, not thicker than in female. Hind wings developed. Abdominal ventrite 5 thickened and depressed at middle of apical half, with apical margin emarginate,
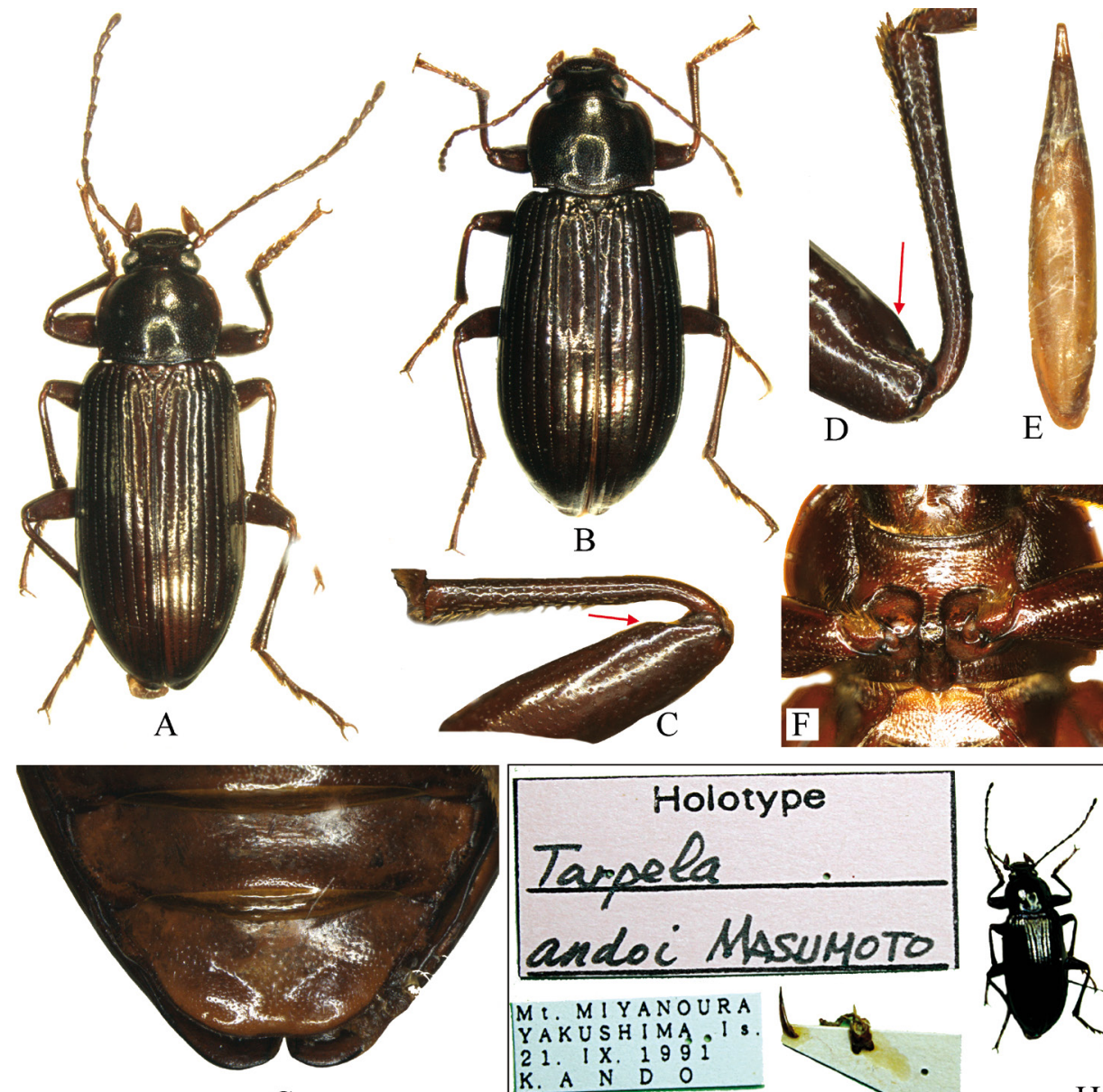

$\mathrm{G}$

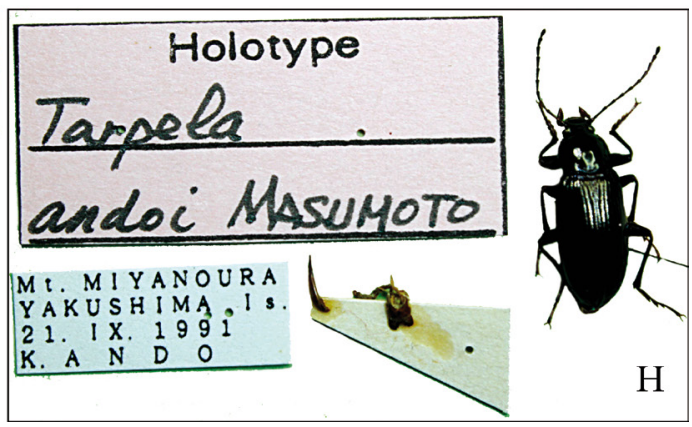

Fig. 13. Nalassus (Nipponalassus) andoi, holotype and paratype. $\mathrm{A}=$ male, holotype, habitus, $\mathrm{B}=$ female paratype, habitus, $\mathrm{C}=$ male fore leg, dorsal margin, $\mathrm{D}=$ male profemur, inner side, $\mathrm{E}=$ aedeagus, dorsal view, $\mathrm{F}=$ prothorax, ventral view, $\mathrm{G}=$ abdominal ventrite $5, \mathrm{H}=$ labels of the holotype 
and not beaded (Figs 13G, 14D, 16B, D). Trochanters with dense hair brushes (Figs 13F, 14B, C, 16C).

Additional characters of male. Mesoventrite covered with short setae and sparse long hairs along mesocoxae. Metaventrite densely pubescent at middle. Outer margin of protrochanters slightly elevated. Inner dorsal margin of profemora protrudent, flattened, often with pubescence near apex. Abdominal ventrites 1 and 2 with dense pubescence at each middle.

Comparison. See key to subgenera of the genus Nalassus.

Composition. The subgenus includes only two Japanese species.

\section{Nalassus (Nipponalassus) andoi (Masumoto, 1993), comb. n.}

(Figs 7I-M, 13, 14)

Masumoto, 1993: 134, figs 4, 10 (Tarpela); Nabozhenko \& Löbl, 2008: 256 (Tarpela).

Type material examined. Holotype, ô (EUM) with labels: “Holotype Tarpela andoi Masumoto", "Mt. Miyanoura, Yakushima Is. 21.IX.1991, K. Ando". Paratypes: 4 o , 2 ㅇ (CKA), Mt. Miyamoura, Yakushima Is., 22.ix.1991, leg. K. Ando.
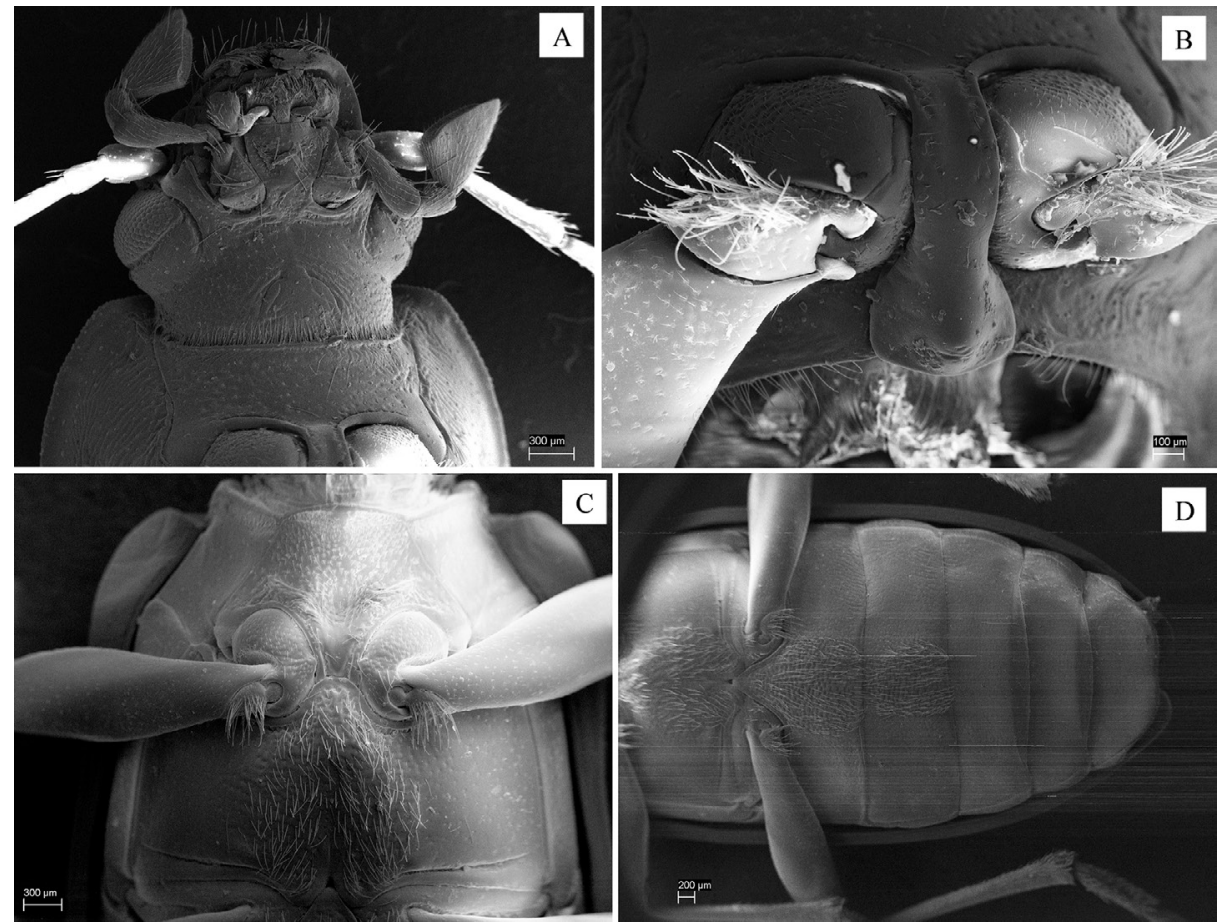

Fig. 14. Nalassus (Nipponalassus) andoi, details of structure. $\mathrm{A}=\mathrm{Head}$, ventral view, $\mathrm{B}=$ prothorax and base of fore legs, ventral side, $\mathrm{C}=$ male meso- and metaventrite, middle legs basally, $\mathrm{D}=$ male abdominal ventrites 
Material examined. $1 \hat{\delta}, 1+$ (CKA): Japan, Yakushima Is., Satsuma, Onoma-pass (Yodogawa), 1400 m, 13.ix.2002 (leg. N. Ohbayashi); 8 exs. (CKA), Onoma-pass (Yodogawa), Yakushima Is., Satsuma, alt. ca. 1,400 m, 14-15.ix.2002 (leg. N. Ohbayashi).

Distribution. Japan (Ōsumi Islands: Yakushima Island).

\section{Nalassus (Nipponalassus) lewisi (Masumoto, 1993), comb. $\mathbf{n}$.} (Figs 7O-R, 15, 16)

Masumoto, 1993: 132, figs 3. 9 (Tarpela); Nabozhenko \& Löbl, 2008: 257 (Tarpela).

Type material examined. Holotype, ô (NMNS) with labels: "Holotype Tarpela lewisi Masumoto", "Komagatake Hakone Date: 1-X-1966 Y. Miyake leg.". Paratypes, 1 ㅇ (CKA), Sasari Pass, Kyoto, 6.vii.1985, leg. K. Ando; 1 ô (CKA), Komagatake, Hakone, 1.x.1966, leg. Y. Miyake; 1 ㅇ (CKA), Mt. Hira, Shiga, 3.vi.1957, leg. T. Shibata; 1 ᄋ (CKA), Mt. Daihi, Kyoto, 16.vi.1957, leg. T. Shibata.

Material examined. 1 ऽ (CKA): Japan, Tokushima, Kayô town, Unagitodoroki Mt., 900-1040 m, 18.x.2008 (leg. Takashi Kurihara); 1 ô, 2 ㅇ (CKA): Japan, Tosa, Kikawamura vill., Yosakoegote pass, $25 . i x .1999$ (leg. S. Nagashima); 1 ภ̊ , 3 ㅇ (CKA), [Ehime-Pref.: Japan] Mt. Onigajyô, alt. 1,000-1,150 m, Uwajima City, 1-2.x.2008 (leg. T. Kurihara); 1 ㅇ (CKA), Kuroson, Tosa, 22-23.v.1999 (leg. K. Ando).

Distribution. Japan: Honshu, Shikoku, Kyushu; S. Korea.

Key to species of the subgenus Nipponalassus subgen. n. (genus Nalassus)

1. Vertex with distinct deep posterior grooves beginning at lower aspect of eyes (Fig. 14A). Male without dense brush of goldish hairs at apex of ven-

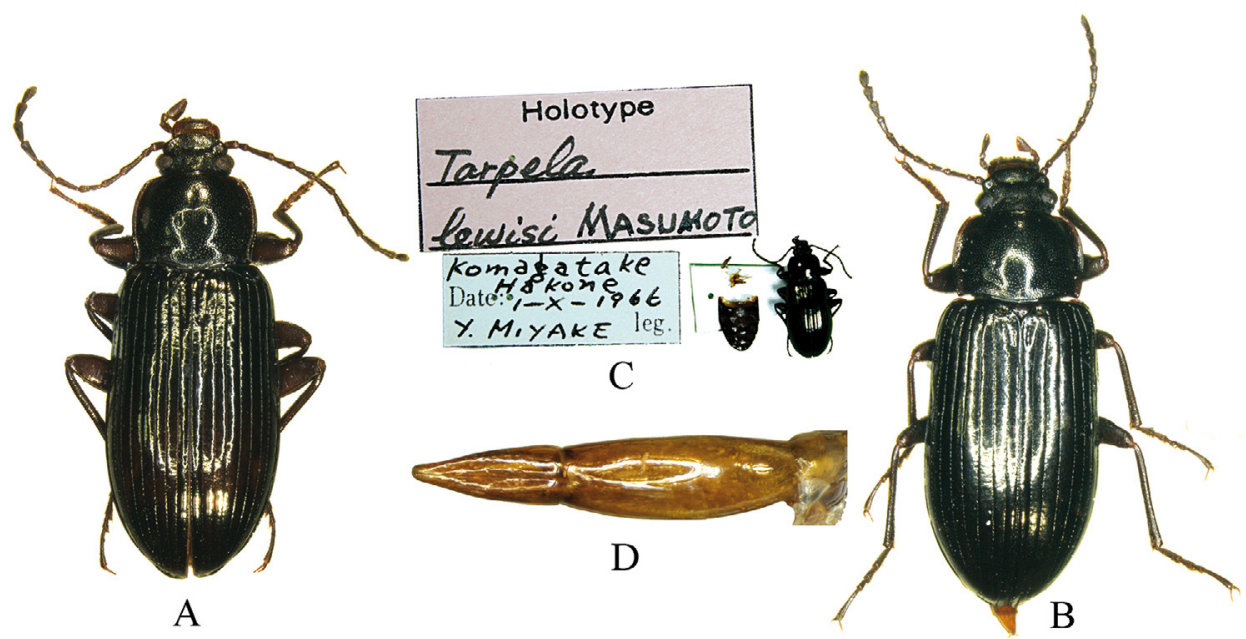

Fig. 15. Nalassus (Nipponalassus) lewisi, holotype and paratype. $\mathrm{A}=$ male, holotype, habitus, $\mathrm{B}=$ female paratype, habitus, $\mathrm{C}=$ labels of the holotype, $\mathrm{D}=$ aedeagus, dorsal view 
tral side of profemora and without dense pubescence at apex (sometimes only with sparse hairs) of abdominal ventrite 5 (Fig. 16B) N. andoi

- Vertex with only wrinkle beginning at lower aspect of eyes (Fig. 16A). Male with dense brush of goldish hairs at apex of ventral side of profemora and with dense pubescence at apex of abdominal ventrite 5 (Fig. 16D)

N. lewisi

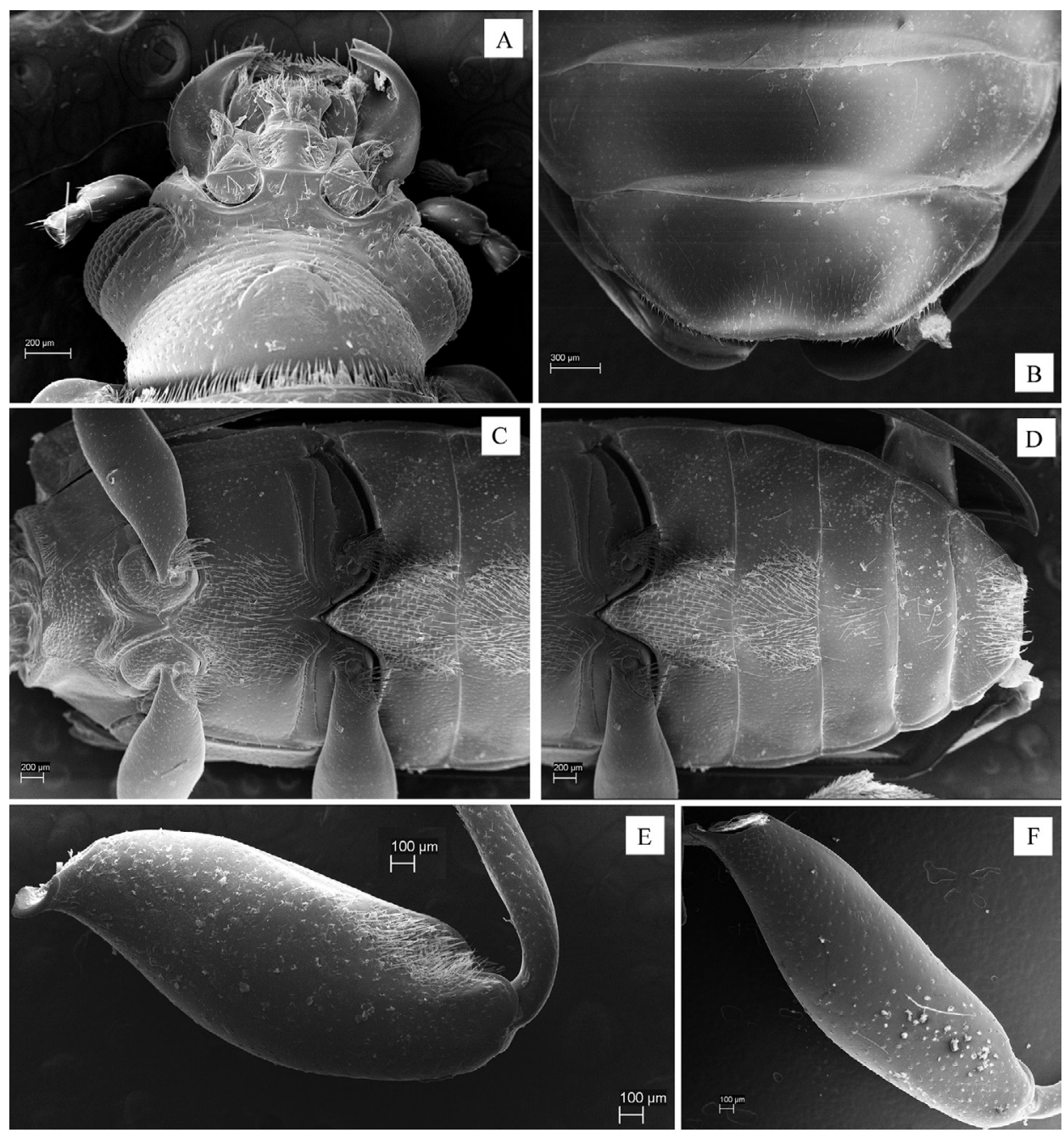

Fig. 16. Nalassus (Nipponalassus) lewisi (A, C-F) and N. (Nipponalassus) andoi (B), details of structure: $\mathrm{A}=$ head, ventral view, $\mathrm{B}=$ male abdominal ventrite $5, \mathrm{C}=$ male meso- and metaventrite, middle legs basally, $\mathrm{D}=$ male abdominal ventrites, $\mathrm{E}=$ male profemur, inner side, $\mathrm{F}=$ male profemur dorsally 


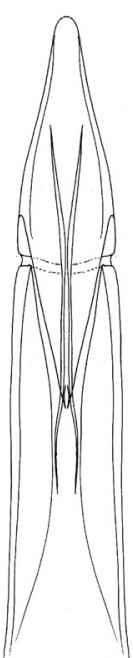

A

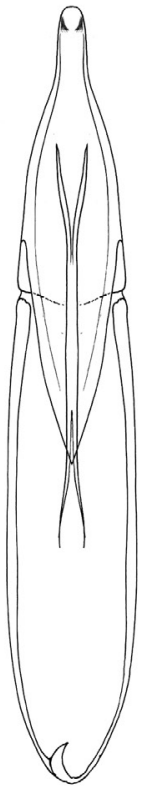

$\mathrm{K}$

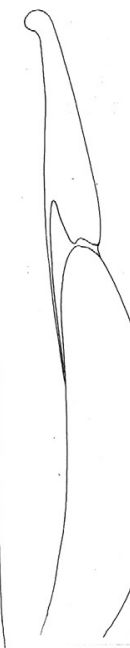

$\mathrm{B}$

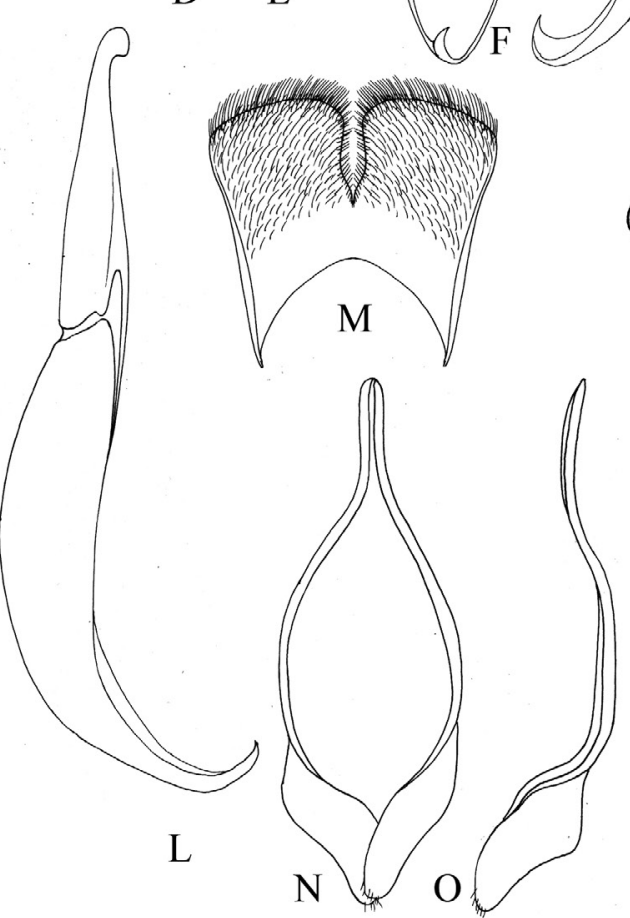

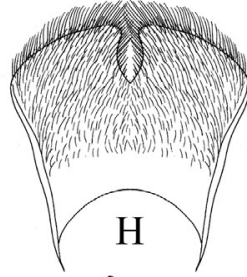

$\alpha$

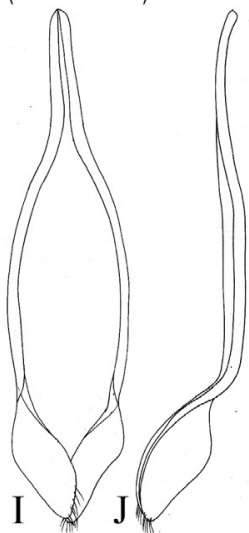

$\mathrm{G}$

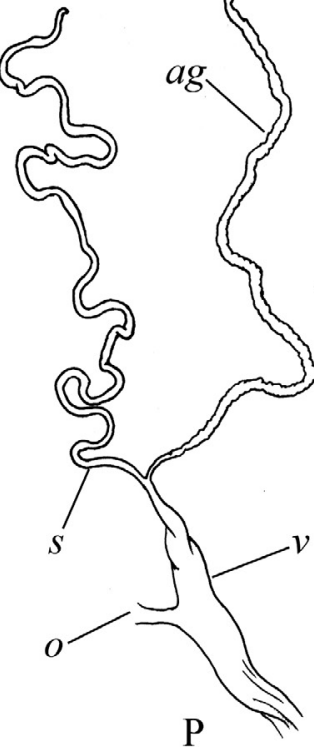

Fig. 17. Asialassus spp., genital structures: A. cordicollis (A-E), A. amamiensis (F-J, $\mathrm{P}), A$. kimurai $(\mathrm{K}-\mathrm{O})$. A, F, K = aedeagus, ventral view, $\mathrm{B}, \mathrm{G}, \mathrm{L}=$ aedeagus, lateral view, $\mathrm{C}, \mathrm{H}, \mathrm{M}$ = male inner sternite VIII, D, I, N = gastral spicula, dorsal view, E, J, O = gastral spicula, lateral view, $\mathrm{P}=$ female genital tubes ( $a g-$ accessory gland of spermatheca, $v-$ vagina, $s-$ spermatheca, $o$ - oviduct) 
Asialassus gen. $\mathrm{n}$.

(Figs 17-26)

Type species: Helops cordicollis Marseul, 1876

Diagnosis. Male. Body slender, shiny, brown, sometimes with metallic glance. Eyes large, convex. Head with or without posterior grooves beginning at lower aspect of eyes. Male antennae constantly thin, antennomeres not more thickened than in female. Anterior margin of frontoclypeus straight. Pronotum large, usually moderately convex. Prothoracic hypomera with longitudinal or irregular wrinkles. Prosternum clearly flattened, with distinct transverse wrinkles before procoxae (Figs 18B, D, 19C, 20B, 21F, G, 22C, 23B, $24 \mathrm{~F}, 25 \mathrm{C}, 26 \mathrm{E})$. Prosternal process with large acute teeth laterally, depressed at middle, strongly projected apically (Figs 18C, 20C, D, 21F, G, 22C, D, 23C, 24F, H, 25B, C, 26E, F). Elytra without humeral calli, with clear striae, punctures in striae connected with each other. Interstriae without tubercles, but with simple coeloconic sensilla. Eighth interstria apically more convex than the rest, connected with elytral margin. Dorsal epipleural carina reaching eighth interval at apex. Elytral epipleura not reaching elytral apex and terminate at level of 4 th and 5 th abdominal ventrites. Hind wings developed (the ability to fly is unknown to us). Mesoventrite slightly depressed at middle. Metaventrite transverse, glabrous. Abdominal ventrites without hair brushes. Male protibiae curved, ladle-shape, widened and flattened apically, often with one or two teeth before apex (Figs 18G, 19B, 21C, D, 22E, F, 24B, C, 25D, E, 26B, C); mesotibiae sometimes with line of large (Fig. 18H) or small granules (Figs 22H, 25F) on ventral side. Male tarsi not widened. Trochanters with single long seta.

Aedeagus 'nalassoid', weakly sclerotized, apical piece with flattened keel at apex (Figs 17A-O).

Female. Body robuster than male, antennae shorter. Prosternal process simple, without teeth (Figs 18E, 19C). Tibiae not modified (Fig. 19B). Procoxae with elevated portion near trochanters, prostenal process depressed at middle between procoxae (Fig. 18F). Genital tubes (Fig. 17P). Spermatheca consists of only one non-branched tube, with clear basal duct. Accessory gland short, a little longer than spermatheca or subequal to spermathecal length.

Comparison. The genus differs from all known Helopini in the structure of toothed and depressed male prosternal process, transverse wrinkles of flattened prosternum before procoxae and elevated outer sides of female procoxae. Asialassus gen. $\mathbf{n}$. is the most close to the genus Nalassus. See differeces between these two genera in the key above.

Composition. The new genus contains six species from Japan and Korean Peninsula. 
Etymology. The name derives from compound word of "Asia" and generic name "Nalassus".

Gender. Masculine.

\section{Asialassus cordicollis (Marseul, 1876), comb. n.}

(Fig. 18)

Marseul, 1876: 141 (Helops); Kwon \& Choi, 1986: 109 (Tarpela); Kim et al., 1990: 181 (Tarpela); Masumoto, 1993: 135, figs 5. 11 (Tarpela); Chûjô \& Lee, 1994: 189 (Tarpela); Kim et al., 1994: 177 (Tarpela); Nabozhenko \& Löbl, 2008: 257 (Tarpela); Jung, 2012: 45 (Tarpela), fig. 23 in plates II, V, X, XIII, XVIII.

Material examined. 2 ô (CKA): Japan, Hôki, Daisen Mt., 14.v.2005 (leg. K. Ando); 1 q (CKA) Japan, Nagasaki, Ôfunakoshi, Mitsushima-chô, 22.vi.2002 (leg. T. Kurihara); 1 đ

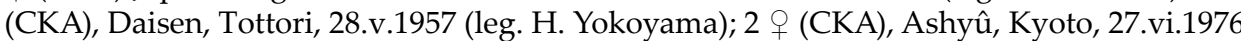
(leg. K. Ando); 1 ð (CKA), Mt. Hikosan, Fukuoka, 1.v.1970 (leg. E. Matsunaga); 1 \& (CKA), Odamiyama, 900 m, Ehime Pref., Japan, 27.v.1970 (leg. H. Kan); 1 § (CKA), Sugitoge-Pass, Kyoto, 18.vi.1986 (leg. M. Hirano); 1 ○ૈ (CKA), Kasuga, Yamato, 15.iv.1984 (leg. K. Ando); 1 우 (CKA), ditto, 28.v.1989 (leg. K. Ando); 1 ㅇ (CKA), Mt. Ishizuchi, Ehime, 25.vii.1971 (leg. H. Kan); 1 q (CKA), Mt. Tsurugi, Tokushima, 10.viii.1971 (leg. H. Kan); 1 q (CKA), Kosugidani, Yakushima, Kagoshima, Japan, 31.VII-2.viii.1999 (leg. K. \& M. Ando); 1 ㅇ (CKA), Kibune, Kyoto, 29.iv.1957 (leg. T. Shibata); 1 우 (CKA), Miike-Lake, Miyazaki, 4.vii.2009 (leg. K. Ando); 1 ㅇ (CKA), Mt. Mikusa-yama, Nose, Osaka, Japan, 31.v.2012 (leg. K. Ando); 1 q (CKA), Nomozaki Cape, Nagasaki, 5-6.vii.2003 (leg. K. Ando); 1 ㅇ (CKA), Mt. Taradake, Nagasaki, 4.vi.2006 (leg. K. Ando); 2 \& (CKA), Mt. Ukidake, Nanatsu Vill., Karatsu, Saga, 26.v.2007 (leg. K. Ando); 1 ๆ (CKA), Kuroson, Tosa, 22-23.v.1999 (leg. K. Ando); 1 (CKA), Mt. O-dake, Shimokoshiki Is., 15.v.1972 (leg. M. Miyahara).

Distribution. Korea (central and southern parts of Korean Peninsula); Japan (Honshu, Shikoku, Kyushu, Awajishima Is., Hirado-shima Is., Koshiki-jima Is.).

\section{Asialassus amamiensis (Kaszab, 1964), comb. n. (Figs 19, 20)}

Kaszab, 1964: 7 (Tarpela); Chûjô, 1978a: 75 (Tarpela); Chûjô, 1978b: 14 (Tarpela); Masumoto, 1993: 136, figs 6. 12 (Tarpela); Nabozhenko \& Löbl, 2008: 256 (Tarpela).

Type material examined. Holotype, $q(\mathrm{OMNH})$ with labels: "Ikari, Amami Is. 6.V.1960 T. Shibata", "Holotypus 1963 + Tarpela amamiensis Kaszab", "Tarpela amamiensis Kasz. Dr Z. Kaszab det., 1963". Paratypes, 1 ㅇ (HNHM) with labels: "Ikari, Amami Is. 12.V.1960 T. Shibata", "Paratypus 1963 9 Tarpela amamiensis Kaszab"; 3 ㅇ (OMNH) with labels: "Ikari, Amami Is. 6.V.1960 T. Shibata", "Paratype", " + Tarpela amamiensis Kaszab Det. M. Chujo 1963"; 1 ㅇ (OMNH) with labels: "Ikari, Amami Is. 22.V.1960 T. Shibata", "Paratype", " o Tarpela amamiensis Kaszab Det. M. Chujo 1963".

Material examined. 2 ô (CKA): Japan, Amami-Ôshima, Yuwan-dake Mt., 13.iii.1988 (leg. S. Saitô); 1 đิ (CKA), Mt. Yuwan, Amami Is., 26.iv.1964 (leg. K. Sako); 1 ô (CKA), Nishinakama, Amami Is., 7.iv.1969 (leg. Y. Maeda); 2 ô (CKA), Mt. Yuwan-dake, Amami- 

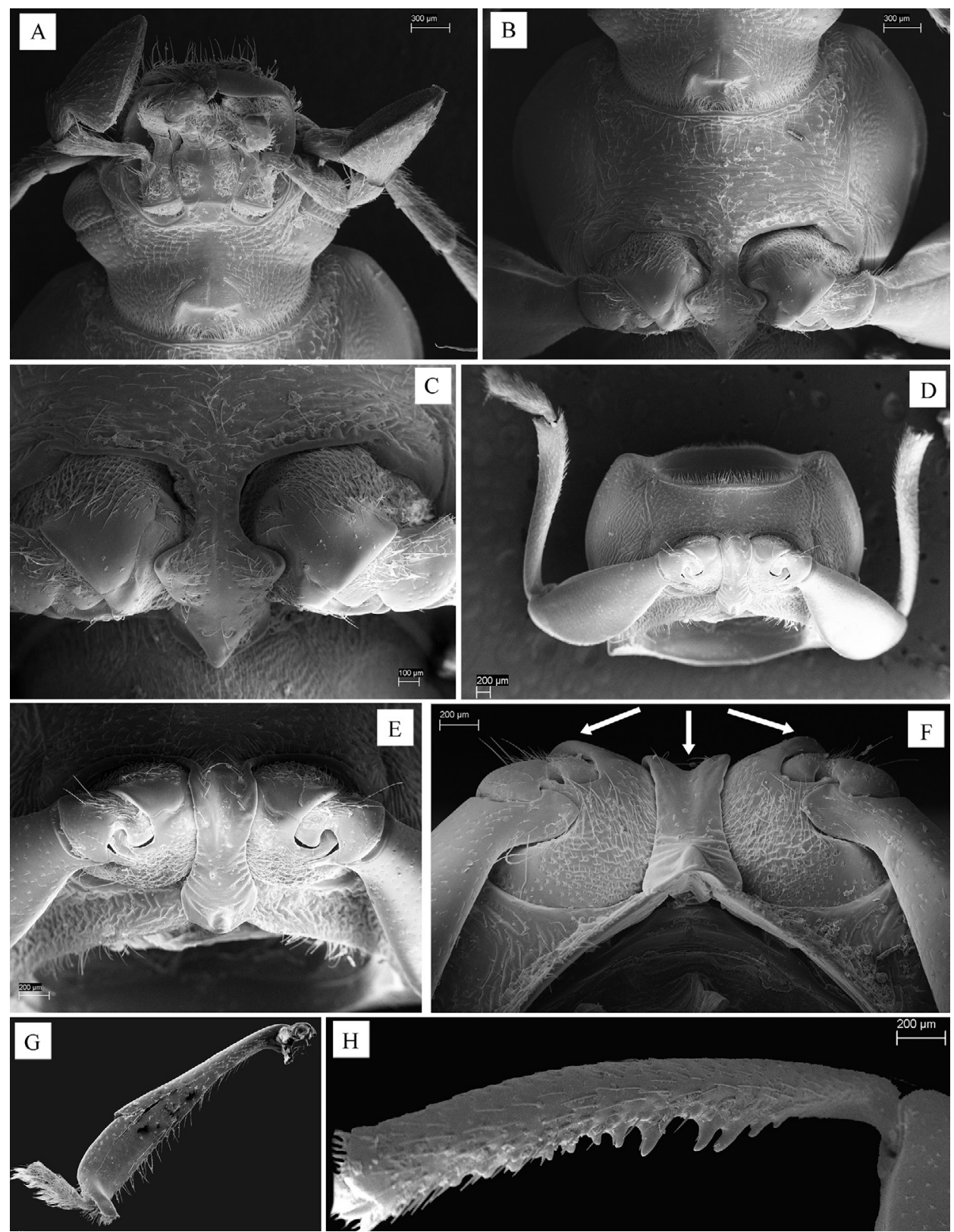

Fig. 18. Asialassus cordicollis, details of structure: $\mathrm{A}=$ head, ventral view, $\mathrm{B}=$ male prosternum, $\mathrm{C}=$ male prosternal process, $\mathrm{D}=$ female prothorax and fore legs, ventral view, $\mathrm{E}=$ female prosternal process, ventral view, $\mathrm{F}=$ female prothorax, posterior transverse view (lateral arrows show elevate margin of procoxae, middle arrow shows depressed prosternal process between procoxae), $\mathrm{G}=$ male protibia, $\mathrm{H}=$ male mesotibia 
Oshima, 13.iii.1988 (leg. T. Yamasaki); 1 đ (CKA), Kikaijima Is., Nakanishi-Park, Amami islands, 4.iii.2012 (leg. Junichi Aoki); 2 + (CKA), Hatsuno, Amami Is., 2.iv.1966 (leg. T. Ito); 1 (CKA), Amami Oshima, Hatsumo, 30. iii.1999 (leg. N. Ohbayashi); 1 (CKA), Japan: Amami-Oshima Is., Mt. Yuwan-dake (outside SPZ, alt. ca. 400 m), Yamato-son (beating: dead twigs), 8.iii.2010 (leg. M. Nishikawa).

Distribution. Japan (The Ryukyus: Amami-Ôshima Is., Okinoerabu-jima Is., Okinawa-jima Is., Kikai-jima Is., and Ishigaki-jima Is.).

\section{Asialassus kimurai (Masumoto, 1996), comb. n.}

(Figs 21, 22, 23)

Masumoto, 1996: 213, figs 2-3 (Tarpela); Nabozhenko \& Löbl, 2008: 257 (Tarpela); Akita \& Masumoto, 2011: 280 (Tarpela).

= Tarpela tokunoshimana Masumoto et Akita, 2001: 20, syn. n.

Type material examined. Tarpela kimurai (NMNS) (Fig. 21). Holotype, ô with labels: “Holotype Tarpela kimurai Masumoto”, “Mt. Ueshiro-dake, (宇江城岳) Gashikami Y., Kume Is. Japan 28.XII.1993 M. Kimura leg.", "K. Akita Collection KAC 62288”.

Tarpela tokunoshimana (NMNS) (Fig. 22). Holotype, ô with labels: "Holotype Tarpela tokunoshimana M\&A.", "Japan: Ryukyus Tokuno-shima Is. Amagi-cho, Hagi-dake, 23.II.1998, M. Kimura”, “Katsumi Akita Collection KAC 10445”, “Coll. Masumoto 2001”.

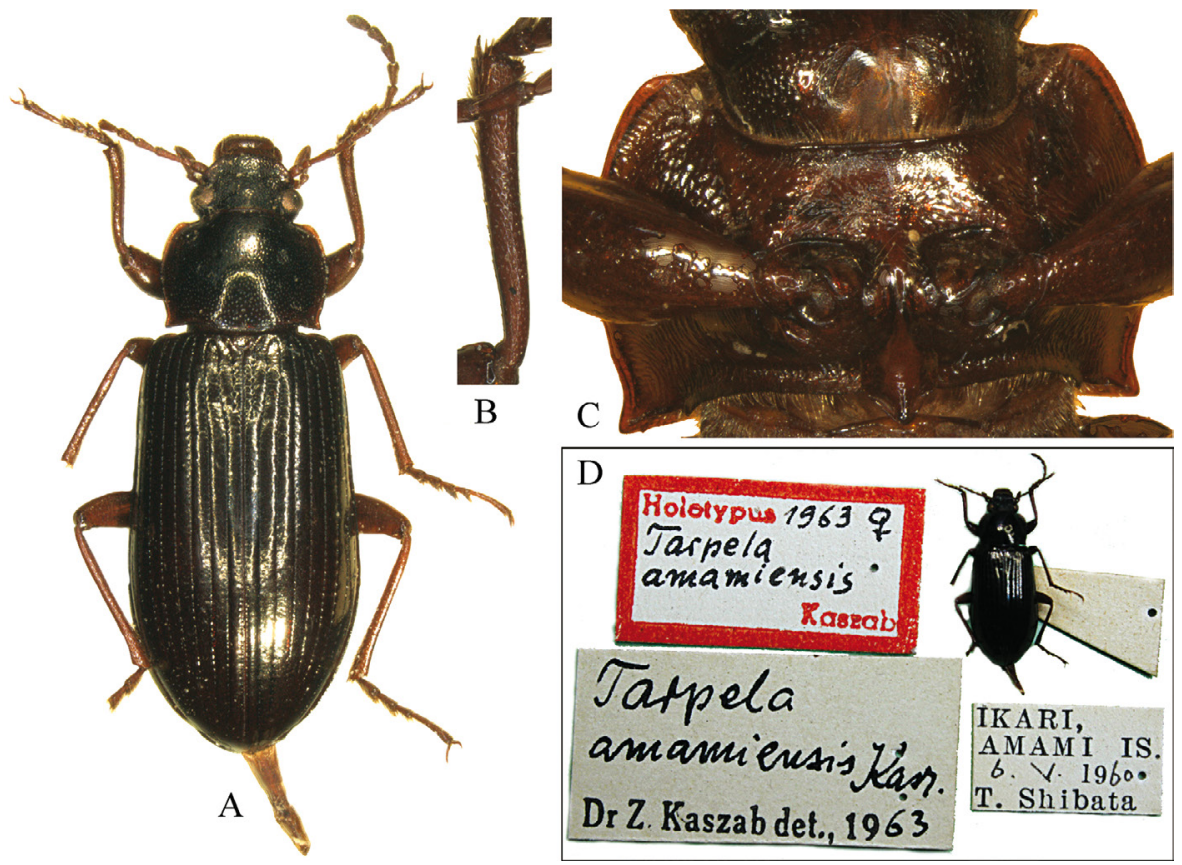

Fig. 19. Asialassus amamiensis, holotype, female: $\mathrm{A}=$ habitus, $\mathrm{B}=$ protibia, $\mathrm{C}=$ prothorax, ventral view, $\mathrm{D}=$ labels of the holotype 
Material examined. $1 \hat{\sigma}$ (CKA), [Kagoshima: Japan] Yamakubiri-rindô, alt. ca. 200 m, Tokunoshima Town, Is. Tokunoshima, 14.iii.2009 (leg. Ta. Kurihara); $2 \hat{\jmath}, 3$ q (CKA), [Kagoshima: Japan] Mt. Amagi, alt. 500-530 m, Tokunoshima Town, Is. Tokunoshima, 16.iii.2009 (leg. Ta. Kurihara); $3 \widehat{\partial}$ (CKA), ditto, 18.iii.2009 (leg. Ta. Kurihara); $1 \widehat{\delta}$ (CKA), ditto, 500-560 m, 13.iii.2009 (leg. Ta. Kurihara); 1 o , 2 ㅇ (CKA), [Kagoshima: Japan] Tete, Tokunoshima Town, Is. Tokunoshima, 16. iii.2009 (leg. Ta. Kurihara); $1 \hat{\delta}, 1$ q (CKA), ditto, 17.iii.2009 (leg. Ta. Kurihara); $1 \hat{\delta}, 1$ † (CKA), ditto, 18. iii.2009 (leg. Ta. Kurihara); $1 \hat{\delta}$ (CKA), Arakawa Higashi, Okinawa Pref., 19.iii.2014 (leg. Y. Tamaki); 1 \& (CKA), Tamatsujiyama, Higashi, Okinawa Pref., 20.iii.2010 (leg. M. Matsumura); 1 ㅇ (CKA), Takae, HigashiSon, Okinawa Is., 20.iv.2017 (leg. K. Ueda).

Distribution. Japan (The Ryukyus: Okinawa-jima Island, Kume-jima Is., Tokashikijima Is., Tokuno-shima Is.).

Notes. Both taxa (tokunoshimana and kimurai) are conspecific (including structures of male genitalia and terminalia) after the study of the holotypes and addition material. Masumото and Акіта (2001: 20) distinguished T. tokunoshimana from T. kimurai in the "smaller body, interocular space with a pair of
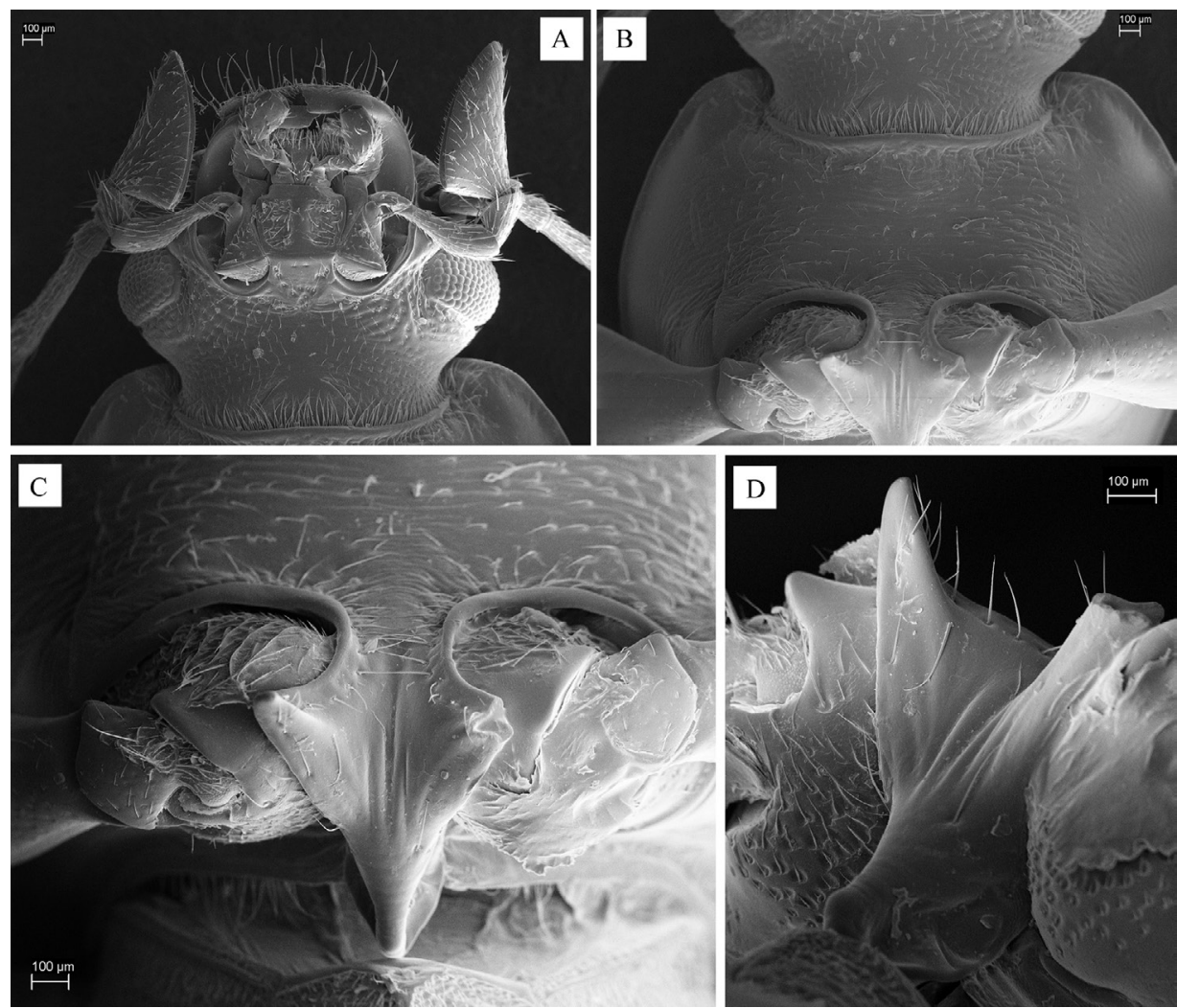

Fig. 20. Asialassus amamiensis, male, details of structure: $\mathrm{A}=$ head, $\mathrm{B}=$ prosternum, $\mathrm{C}=$ prosternal process, ventral view, $\mathrm{D}=$ prosternal process, lateral view 
impressions, narrower diatone (three times the width in T. kimurai), and different ratios of the lengths of antennal and tarsal segments". All these characters are variable in different populations. As a result a new synonymy is proposed.

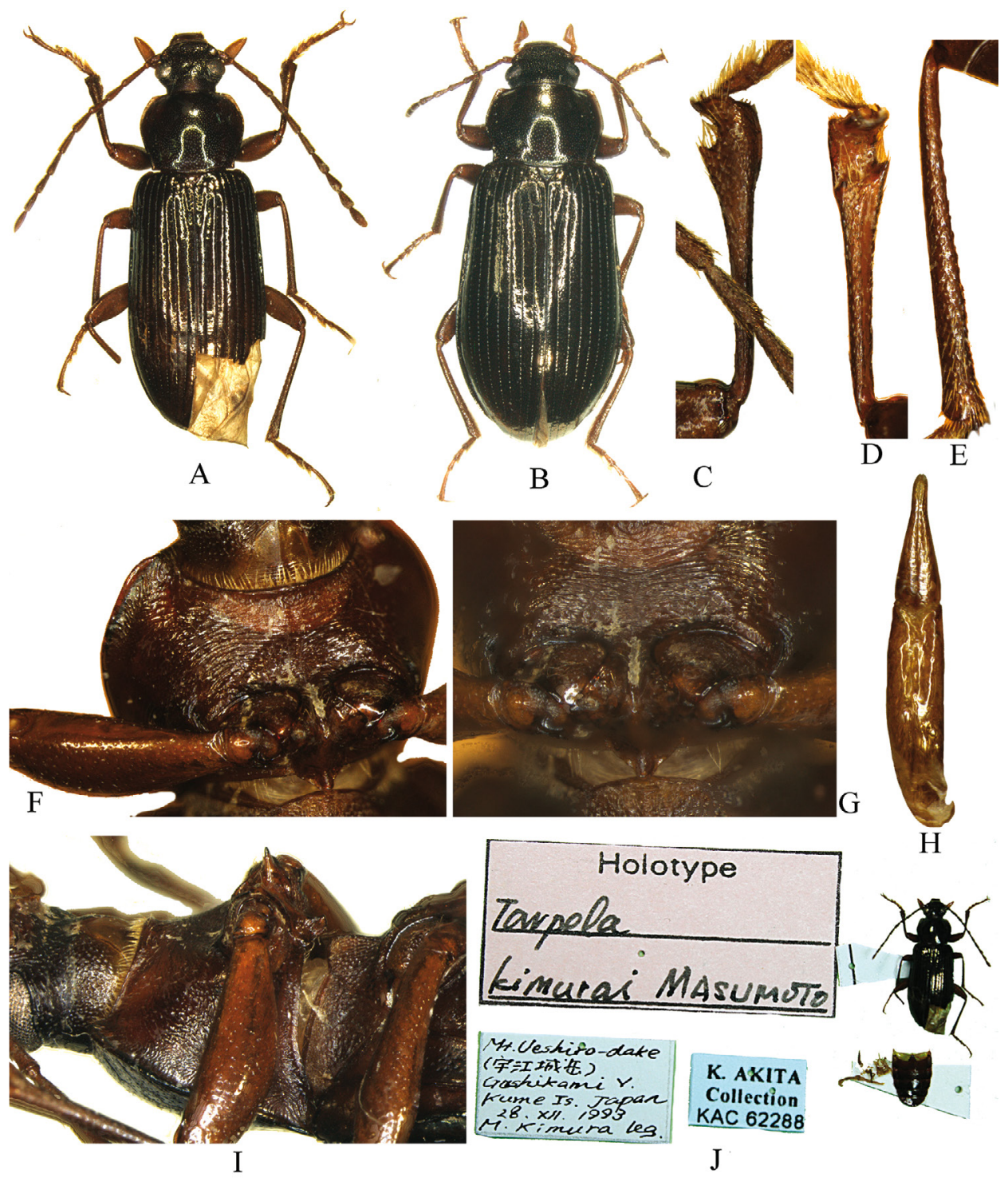

Fig. 21. Asialassus kimurai, holotype and paratype: $\mathrm{A}=$ holotype, male, habitus, $\mathrm{B}=$ paratype, female, habitus, $\mathrm{C}=$ male protibia, dorsally, $\mathrm{D}=$ male protibia, ventrally, $\mathrm{E}=$ male mesotibia, $\mathrm{F}=$ male prothorax ventro-laterally, $\mathrm{G}=$ male prothorax, ventrally, $\mathrm{H}=$ aedeagus, dorsal view, I = male prothorax, laterally, $\mathrm{J}=$ labels of the holotype 


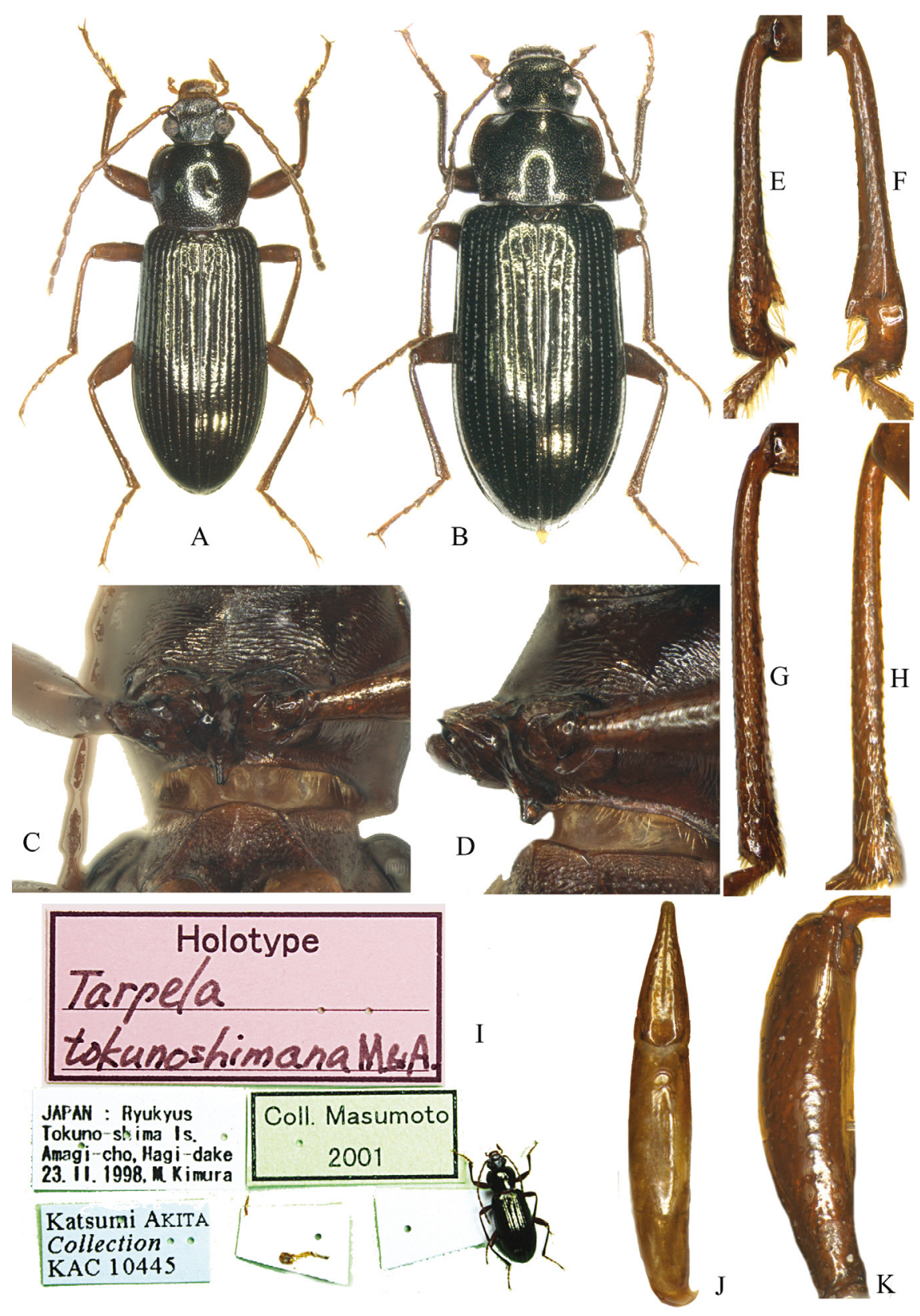

Fig. 22. Asialassus kimurai, holotype and paratype of the new junior synonym Tarpela tokunoshimana: $\mathrm{A}=$ holotype, male, habitus, $\mathrm{B}=$ paratype, female, habitus, $\mathrm{C}=$ male prothorax, ventrally, $\mathrm{D}=$ male prothorax, laterally, $\mathrm{E}=$ male protibia, dorsally, $\mathrm{F}=$ male protibia, ventrally, $\mathrm{G}=$ male mesotibia, dorsally, $\mathrm{H}=$ male mesotibia, ventrally, $\mathrm{I}=$ labels of the holotype, $\mathrm{J}=$ aedeagus, dorsal view, $\mathrm{K}=$ male profemur, inner side 


\section{Asialassus tsushimanus (Nakane, 1979), comb. n.}

(Fig. 24)

Nakane, 1979: 114, figs 5-6 (Tarpela); Masumoto, 1993: 136, fig. 13 (Tarpela); Nabozhenko \& Löbl, 2008: 257 (Tarpela).

Type material examined. Holotype, $\widehat{\jmath}$ (MHU) with labels: “Holotype”, “Mt. Furisode Tsushima Is., 14--III-1960, Coll. S. Tsuyuki" , "Tarpela tsushimana Nak. Det. T. Nakane", “Nakane coll. SEHU Japan 1999”, “0000004454 Sys. Ent Hokkaido Univ. Japan [SEHU]”, “クロ-H 07689”.

Material examined. 1 ㅇ (CKA), Mt. Yatate, Tsushima, 3.v.1968 (leg. Y. Kiyoyama); 1 † (CKA), Tsushima, Nagasaki Pref., v.1972 (leg. S. Fukuda); 1 ภ (CKA), FunashinouchiHigashizato; Kamiagata, Tsushima, Nagasaki, 2.iv.2006 (leg. Y. Utsunomiya); $1 \hat{\sigma}, 2$ 우 (CKA), Mt. Tatera, Tsushima Is., Nagasaki, 22-23.iv.2006 (leg. K. Ando); 1 + (CKA), Mt. Yatateyama, Tsushima Is., Nagasaki, 22-23.IV.2006 (leg. K. Ando); 1 ○े (CKA), Uemizaka, Izuhara, Tsushima Is., 23.iv.2006 (leg. K. Ando).

Distribution. Japan (Tsushima Is., Gotô islands (Fukue-jima Is.)).
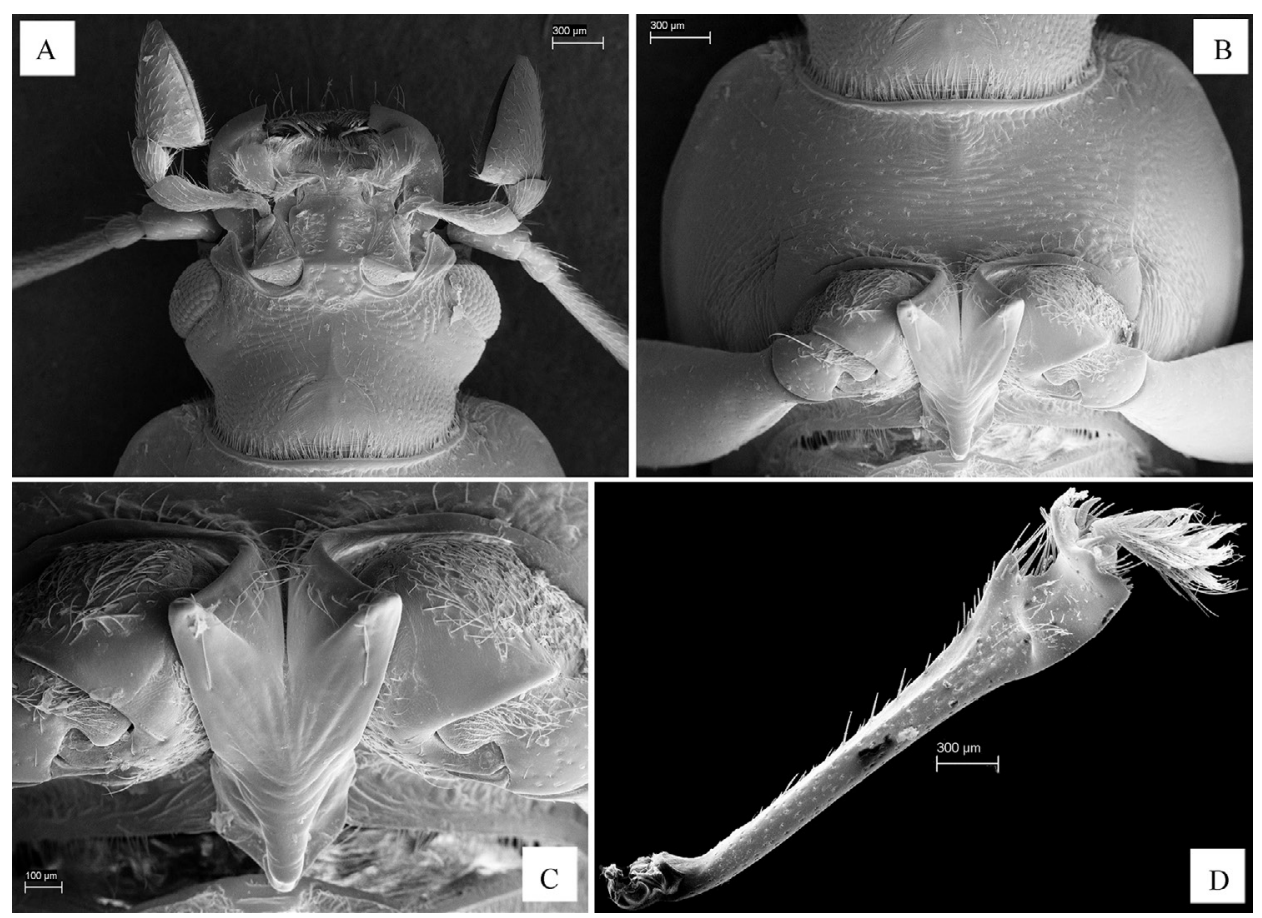

Fig. 23. Asialassus kimurai, details of structure, male: $\mathrm{A}=$ head, ventral view, $\mathrm{B}=$ prothorax, ventral view, $\mathrm{C}=$ prosternal process, $\mathrm{D}=$ protibia, ventrally 

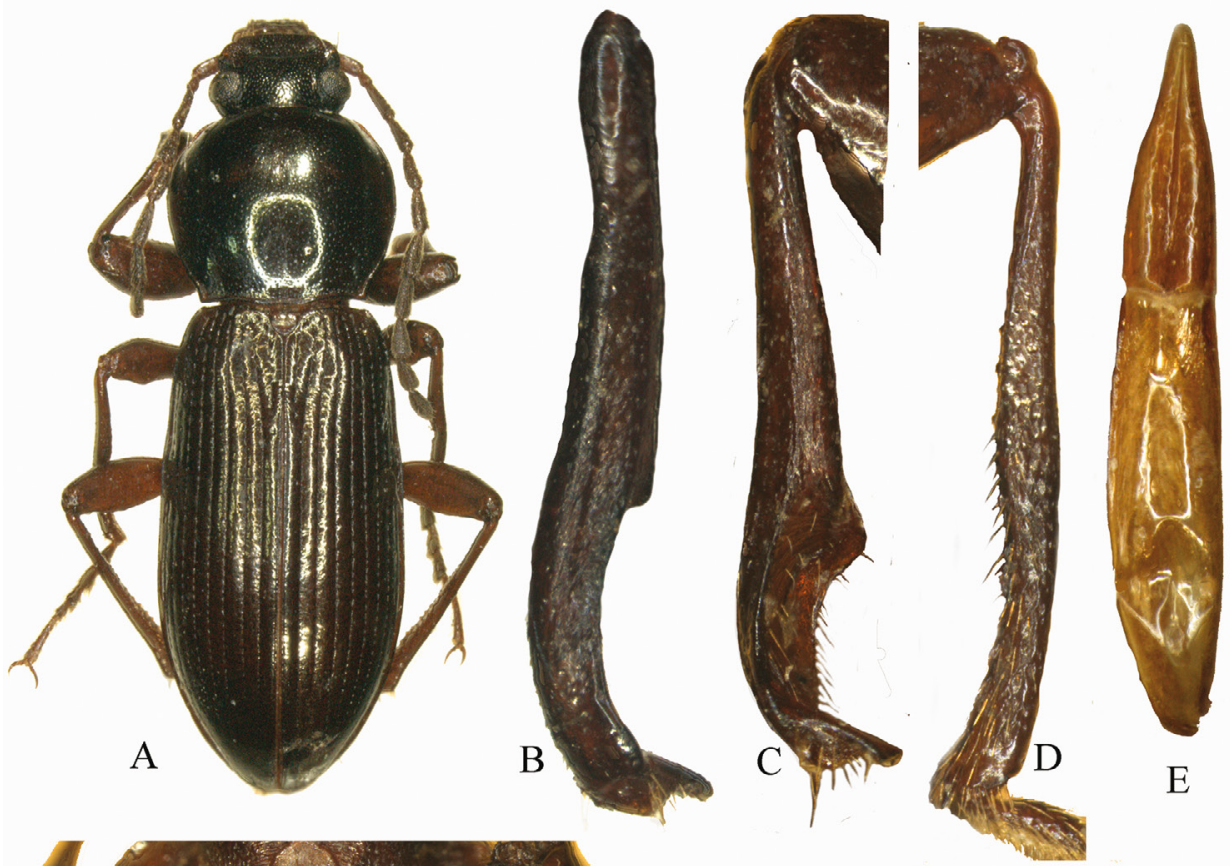

$\mathrm{E}$
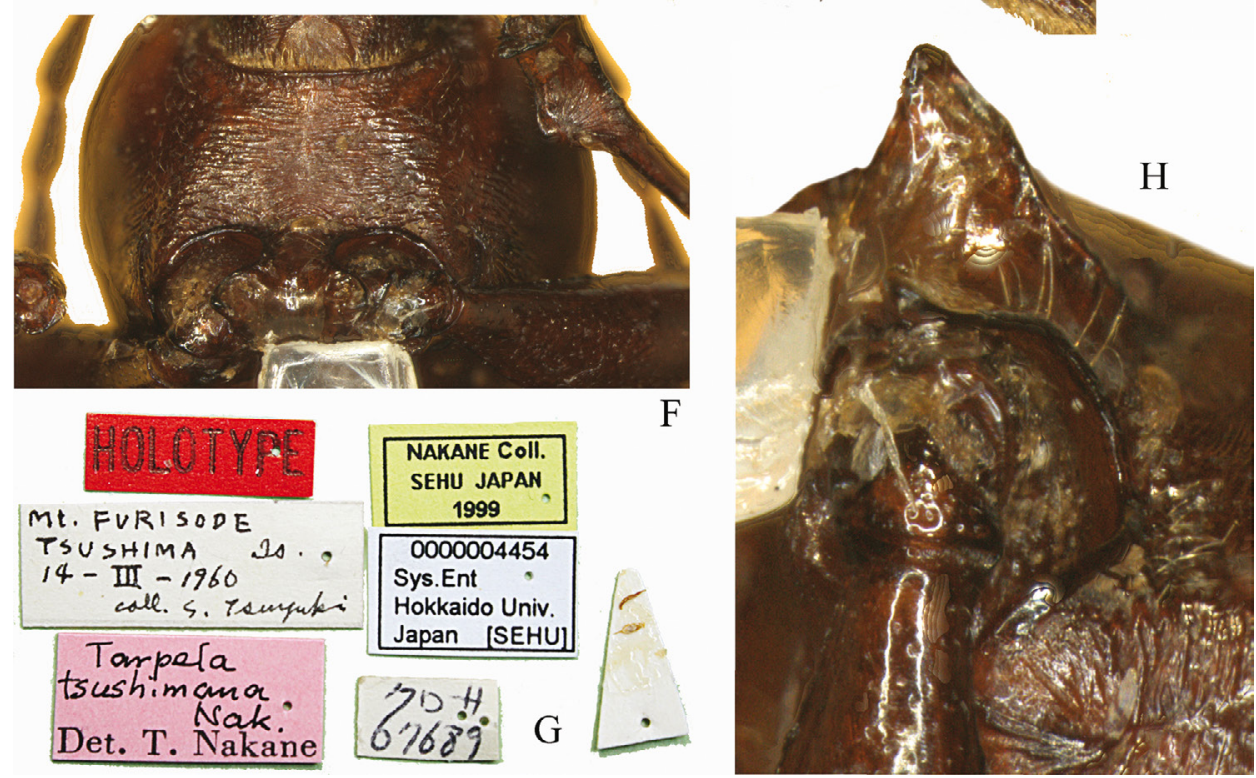

Fig. 24. Asialassus tsushimanus, male, holotype: $\mathrm{A}=$ habitus, $\mathrm{B}=$ protibia, laterally, $\mathrm{C}=$ protibia, ventrally, $\mathrm{D}=$ mesotibia, $\mathrm{E}=$ aedeagus, dorsal view, $\mathrm{F}=$ prothorax, ventral view, $\mathrm{G}=$ labels of the holotype, $\mathrm{H}=$ prothorax, lateral view 


\section{Asialassus todai (Ando, 2006), comb. n.}

(Fig. 25)

Ando, 2006: 29, figs 1-3 (Tarpela); Nabozhenko \& Löbl, 2008: 257 (Tarpela).

Type material examined. Holotype, $\widehat{\jmath}$ (EUM) with labels: "Holotype Tarpela todai Ando n. sp.", “[石垣] 川平石崎 沖縄県石垣市 1. I. 2004 leg. 戸田尚希” (Japanese label: [Ishigaki] Kabiraishizaki, Ishigaki city, Okinawa Pref., 1.i.2004, leg. Naoki Toda). Paratypes (CKA), + with labels: “[Ryûkyû: Japan] Mt. Omoto Ishigaki-shi 29.iii.1999 (石垣島) T. Kurihara leg.", "Paratype Tarpela todai Ando, 2006"; 1 ô, Omoto-dake, Okinawa Pref., Ishigakicity, 19.iii.1999, leg. Takashi Kurihara (オモト岳, 沖縄県・石垣市, 1999年3月19日，栗原 隆採集).

Material examined. $1 \curvearrowright, 2$ 우 (CKA), Ishigakijima Is., Nagura, Okinawa, 17.I.2006 (T. Nakata leg.).

Distribution. Japan (Yaeyama Islands: Ishigaki-jima Is.).

Asialassus adachii (Akita et Masumoto, 2009), comb. n. (Fig. 26)

Akita \& Masumoto, 2009: 77, figs 1-8 (Tarpela).

Type material examined. Holotype, $\widehat{O}$ (NMNS) with labels: "Holotype Tarpela adachii Akita et Masumoto, 2009", “Oshima Is., Danjyo Isls. Nagasaki Japan. 4.v.2005 Kazuo Adachi leg.", "K. Akita Collection KAC 32714".

Distribution. Japan (Danjo Islands: Oshima Is.).

Key to the species of the genus Asialassus based on structures of male

1. Protibiae strongly flattened and bent down apically, without additional processes or teeth (Fig. 18G). Mesotibiae with strong and large 10-12 teeth on inner margin (Fig. 18A)

A. cordicollis

- Protibiae ladle-shaped, bent down at apex, with additional one or two teeth or tooth-shaped process apically (Figs 21C,D, 22E,F, 23D, 24B,C, 25D,E, 26B,C). Mesotibiae without teeth or with several very small teeth on inner side near apex

2. Protibiae with two acute distinct teeth before apex (Figs 21C,D, 22E,F, 23D)

A. kimurai

- Protibiae with a rounded or angulate inner process on inner margin (Figs 24B,C, 25S,E, 26D,C)

3. Mesotibiae almost straight (not thickened at middle, with several small acute teeth on inner margin near apex) (Fig. 25F)

A. todai 

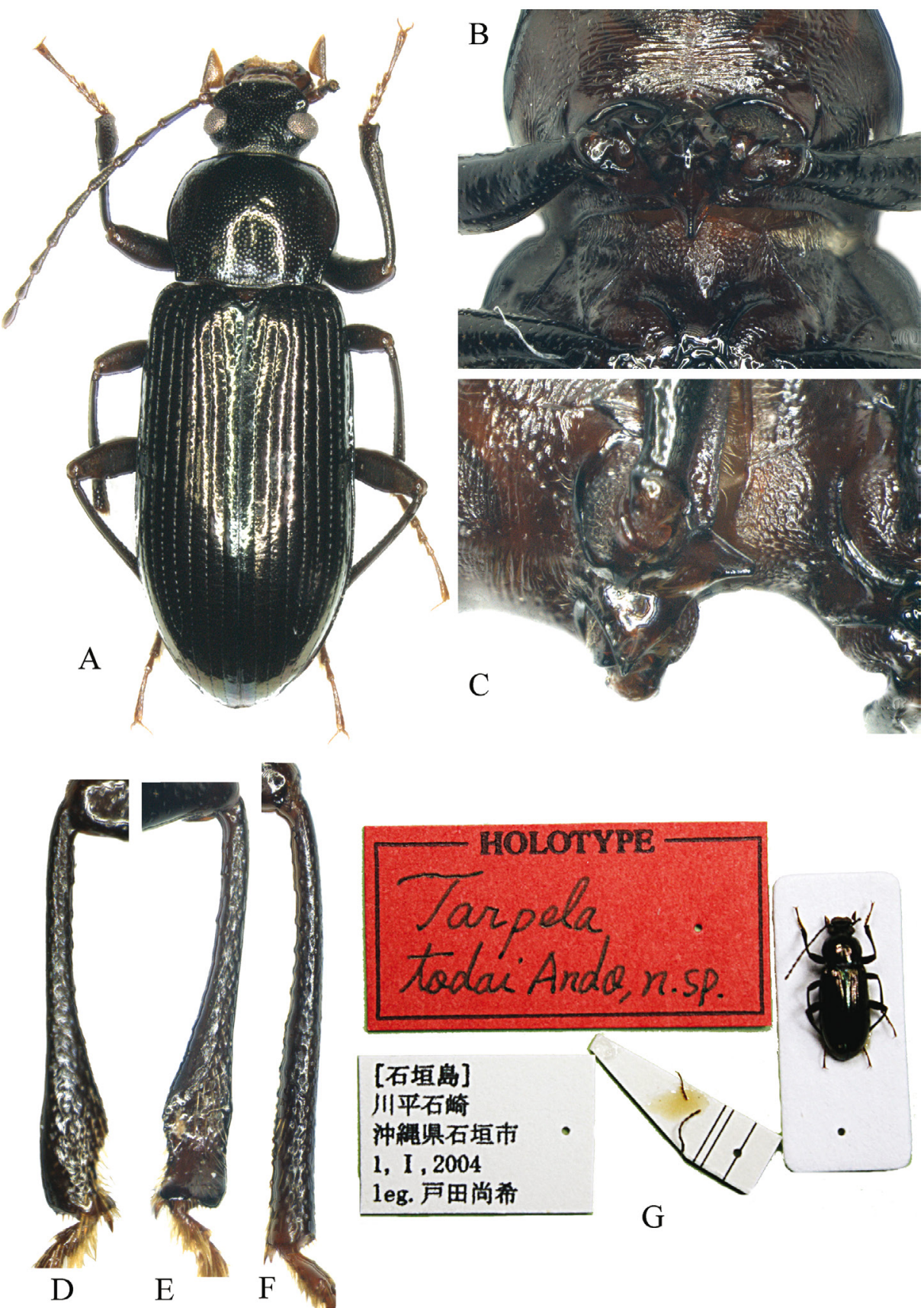

\section{[石垣岛] 川平石崎} 沖縄県石垣市 $1, \mathrm{I}, 2004$ leg. 戸田尚希
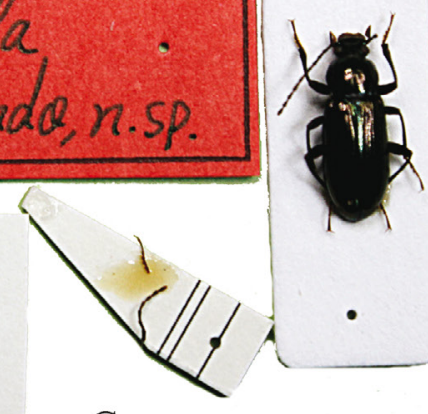

Fig. 25. Asialassus todai, male, holotype: $\mathrm{A}=$ habitus, $\mathrm{B}=$ prothorax, ventral view, $\mathrm{C}=$ prothorax, lateral view, $\mathrm{D}=$ protibia, dorsal view, $\mathrm{E}=$ protibia, ventral view, $\mathrm{F}=$ mesotibia, $\mathrm{G}=$ labels of the holotype 
- $\quad$ Mesotibiae distinctly bent (Figs 24A,D, 26A,D)

4. Mesotibiae not thickened at middle. Pronotum moderate in size, narrower than elytra at base

A. amamiensis

- Mesotibiae thickened at middle (Figs 24D, 26D). Pronotum very large, wider than elytra at base (Figs 24A, 26A)

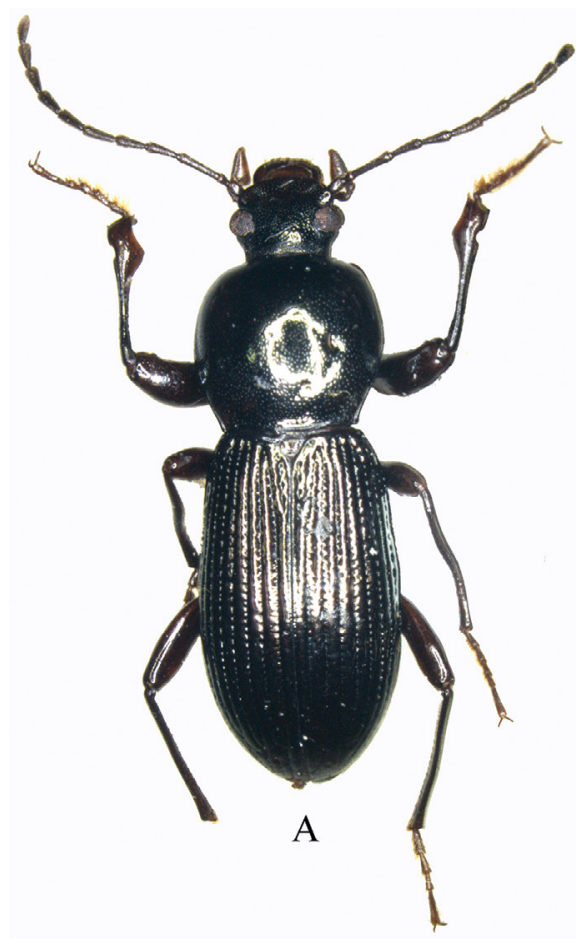

B
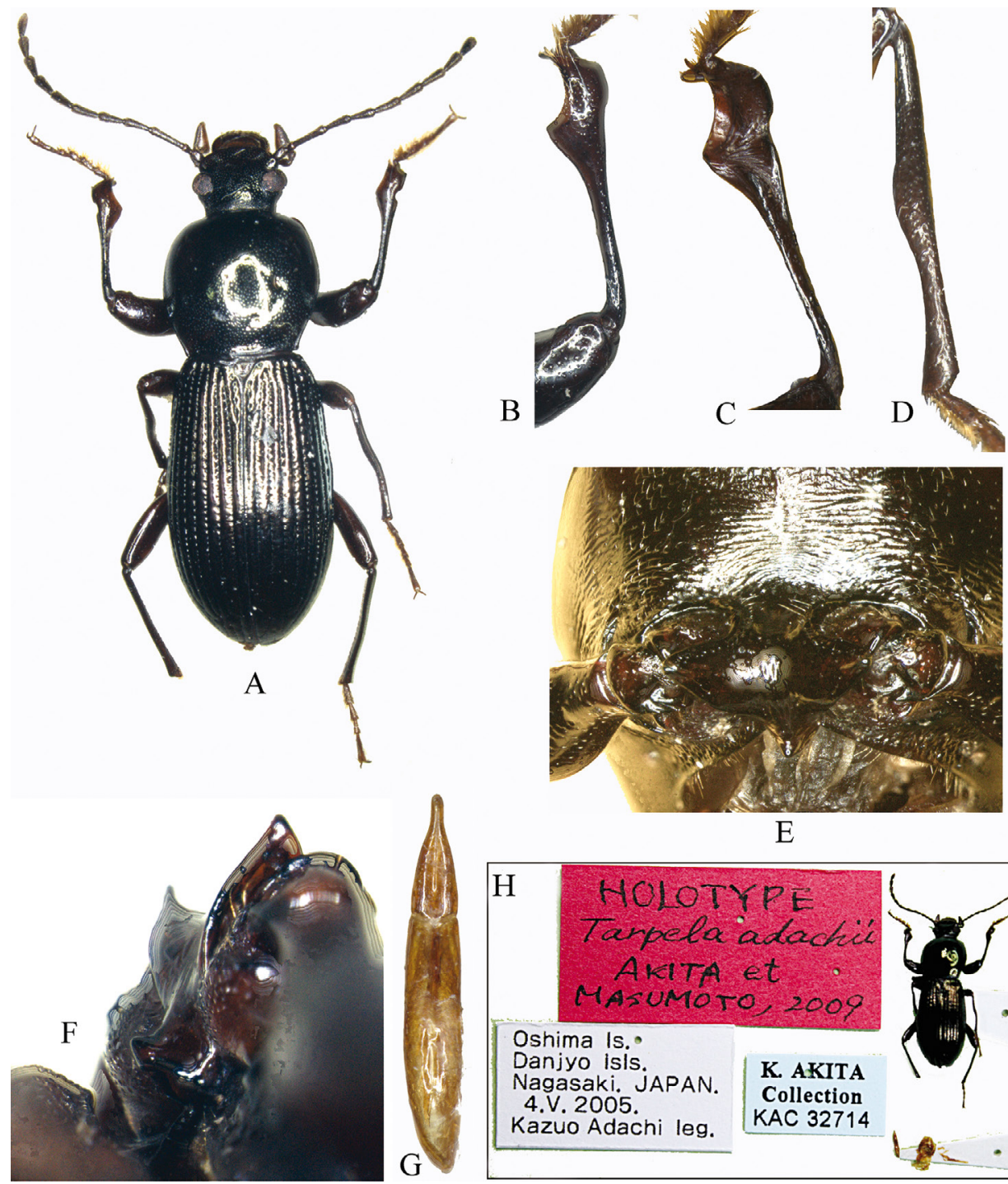

E

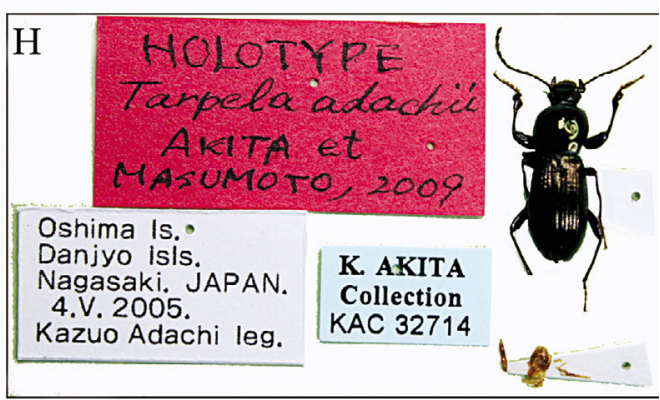

Fig. 26. Asialassus adachii, male, holotype: $\mathrm{A}=$ habitus, $\mathrm{B}=$ protibia dorsally, $\mathrm{C}=$ protibia ventrally, $\mathrm{D}=$ mesotibia, $\mathrm{E}=$ prothorax, ventral view, $\mathrm{F}=$ prosternal process, lateral view, $\mathrm{G}=$ aedeagus, $\mathrm{H}=$ labels of the holotype 
5. Protibiae with clear large triangular inner process on inner margin and distinct emargination on outer margin near apex (dorsal or ventral view) (Figs 26B,C)

A. adachii

- Protibiae with simple inner rounded process on inner margin and not emarginate outer margin near apex (dorsal or ventral view) (Figs 24A,F)

A. tsushimanus

Acknowledgements - We thank to Dr Shûhei Nomura (NSMS), Dr Masahiro Ôhara (MHU), Dr Eva Sprecher-Uebersax and Dr Isabelle Zürcher (NHMB), Dr Wolfgang Schawaller (SNMS), Mr Stanislav Bečvář (Prague, Czech Republic), Dr Ottó Merkl (HNHM), Dr Antoine Mantilleri (MNHP), Dr Hiroyuki Yoshitomi (EUM), Dr Kimio Masumoto (Tokyo), Mr Maxwell Barclay (BNHM), Mr Shigehiko Shiyake (OMNH), Mr Masashi Matsumura (Okinawa), and many colleagues mentioned in "material examined" for their loan of type materials or gifting important specimens for this study. The authors are much obliged to Rolf Aalbu (Department of Entomology, California Academy of Sciences, San Francisco, California, USA) for the linguistic review, Dr Denis Kasatkin (Rostov Branch of All-Russian Center for Plant Quarantine, Rostov-on-Don) for preparation of photographs of Apterotarpela, Stenohelops, Catomus and Taiwanese Nalassus, to Vladimir Schmatko (Southern Scientific Centre of the Russian Academy of Sciences, Rostov-on-Don) for photographs of detalis of American Tarpela. The study was supported by the Russian Foundation for Basic Research (grant 18-04-00243-A) for M. Nabozhenko.

\section{REFERENCES}

Акіта, K. \& Mаsumoто, K. (2009): New or little known tenebrionid beetles (Coleoptera, Tenebrionidae) from Japan (8) Two new species from Danjo-guntô and Ryukyu Islands. - Entomological Review of Japan 64: 77-82.

Акіта, K. \& Masumoто, K. (2012): New or little known tenebrionid beetles (Coleoptera, Tenebrionidae) from Japan: (11) Description of seven new species, up-grading of a subspecies to the species rank, and a new distributional record of a species. - Elytra, new series 1: $275-294$.

Allard, E. (1876): Révision des Helopines vrais de Lacordaire. - L'Abeille, Journal d'Entomologie 14: 1-80.

Ando, K. (2006): Contribution to the knowledge of Japanese Tenebrionidae (3) (Coleoptera). - Entomological Review of Japan 61: 29-32.

Ando, K., Merkl, O., Jeng, M-L., Chan, M-L. \& Hayashi Y. (2016): Catalogue of Formosan Tenebrionidae (Insecta: Coleoptera). - Japanese Journal of Systematic Entomology, Supplementary Series 1: 1-112.

Antoine, M. (1949): Notes d'entomologie Marocaine XLIV. Matériaux pour l'étude des Helopinae du Maroc (Col. Tenebrionides). - Bulletin de la Société des Sciences Naturelles du Maroc 25-27: 123-162.

Ardoin, P. (1958): Contribution à 1'étude des Helopinae de France (Col. Tenebrionidae). Annales de la Société Entomologique de France 127: 9-49. 
CHûjô, M.T. (1975): Tenebrionidae of the Nansei Islands I (Coleoptera). - Esakia 9: 15-23, $2 \mathrm{pl}$.

CHÛJô, M.T. (1977): Tenebrionidae of the Nansei Islands II (Coleoptera). - Esakia 10: 1-19.

CHûjô, M.T. (1978a): Tenebrionidae of the Nansei Islands III (Coleoptera). - Esakia 11: 63-80.

CHûjô, M.T. (1978b): Tenebrionidae of the Nansei Islands IV (Coleoptera). - Esakia 12: 1-16.

Chûjô, M.T. \& LeE, C.E. (1993): Korean Tenebrionidae (Insecta, Coleoptera). - Esakia 33 $109-122$.

Cifuentes-Ruiz, P., Zaragoza-Caballero, S., Ochoterena-Booth, H. \& Morón, M.A. (2014): A preliminary phylogenetic analysis of the New World Helopini (Coleoptera, Tenebrionidae, Tenebrioninae) indicates the need for profound rearrangements of the classification. - ZooKeys 415: 191-216. https://doi.org/1.3897/zookeys.415.6882

Español, F. (1956): Los Probaticus de España (Col. Tenebrionidae). - Eos, Revista Española de Entomología 32: 83-123.

Español, F. (1961): Los Cylindronotini de la Peninsula Ibérica (Col. Tenebrionidae). - Eos, Revista Española de Entomología 37: 135-160.

Fairmaire, L. (1888): Descriptions de coléoptères de l'Indo-Chine. - Annales de la Société Entomologique de France (ser. 6) 8: 333-378.

Gebien, H. (1911): Tenebrionidae, Trictenotomidae. pars. 28, 37. Pp. 1-740. In: Junk, W. \& Schekling, S. (eds): Coleopterorum Catalogus auspiciis et auxilio W. Junk editus a S. Schenkling. Vol. 18. - W. Junk, Berlin.

Gebien, H. (1914): H. Sauter's Formosa-Ausbeute. Tenebrionidae (Coleopt.). Archiv für Naturgeschichte, A 79(9): 1-58, 13 figs., 1 pl.

Gebien, H. (1943): Katalog der Tenebrioniden. Teil. 3. - Mitteilungen der Münchner Entomologischen Gesellschaft 33: 399-430 (778-809), 895-926 (810-841).

Heyden, L. (1887): Verzeichnis der von Herrn Otto Herz auf der chinesischen Halbinsel Korea gesammelten Coleopteren. - Horae Societatis Entomologicae Rossicae 21: 243-273.

Horn, G.H. (1870): Revision of the Tenebrionidae of America, north of Mexico. - Transactions of the American Philosophical Society 14: 64-404. https://doi.org/10.2307/1005214

Jung, B-H. (2012): Insect Fauna of Korea. Vol. 12. No 5. Arthropoda: Insecta: Coleoptera: Tenebrionidae: Tenebrioninae. National Institute of Biological Resources Publ., Incheon, 115 pp.

Kaszaв, Z. (1954): Über die von Herrn J. Klapperich in der chinesischen Provinz Fukien gesammelten Tenebrioniden (Coleoptera). - Annales Historico-Naturales Musei Nationalis Hungarici (S. N.) 5: 248-264.

Kaszaв, Z. (1964): Über die Tenebrioniden einiger japanischen Inseln (II). - Entomological Review of Japan 17: 1-10.

Kaszab, Z. (1968): Tenebrionidae und Meloidae (Coleoptera) aus Nord-Korea, gesammelt von M. Mroczkowski und A. Riedel im Jahre 1965. - Annales Zoologici 26: 7-14.

KAsZAB, Z. (1980): Angaben zur Kenntnis der Tenebrioniden Nordvietnams (Coleoptera). Annales Historico-Naturales Musei Nationalis Hungarici 72: 169-221.

Kendall, D. A. (1974): The structure of defence glands in some Tenebrionidae and Nilionidae (Coleoptera). - Transactions of the Royal Entomological Society of London 125: 437-487. https://doi.org/10.1111/j.1365-2311.1974.tb02308.x

Keskin, B., Nabozhenko, M. \& Alpagut-Keskin, N. (2017): Taxonomic review of the genera Nalassus Mulsant, 1854 and Turkonalassus gen. nov. of Turkey (Coleoptera: Tenebrionidae). - Annales zoologici 67: 725-747. https://doi.org/10.3161/00034541A NZ2017.67.4.009

Kiм, C. W. \& KIm, J. I. (1972): Insect fauna of Gucheondong, Muju-gun. - Report of the Korean Association for Conservation of Nature 5: 65-101. [In Korean] 
Kim, J. I., Kim, B. J., Lee, O. J. \& ParK, H. C. (1990): Faunistic study on the insect from Mt. Songni. Report of the Korean Association for Conservation of Nature 29: 163-193.

Kim, J. I., Kwon, Y. J., Paik, J. C., Lee, S. M., Ahn, S. L., Park, H. C. \& Chu, H. Y. (1994): Order 23. Coleoptera. Pp. 117-214. In: The Entomological Society of Korea and Korean Society of Applied Entomology (eds): Check list of insects from Korea. Kon-Kuk University Press, Seoul.

Kwon, Y. J. \& CHOI, Y. S. (1986): Check list of family Tenebrionidae from Korea. - Insecta Koreana 6: 105-113.

Lewis, G. (1894): On the Tenebrionidae of Japan. - The Annals and Magazine of Natural History (6) 13: 377-400, 465-485, pl. XIII. https://doi.org/10.1080/00222939408677720

Liv, H-Y. \& ReN, G-D. (2010): A new species of the genus Catomus Allard from China (Coleoptera, Tenebrionidae). - Acta Zootaxonomica Sinica 35: 71-73.

MARseul, S.A. DE (1876): Coléoptères du Japon recueillis par M. Georges Lewis [sic: George Lewis]. Énumération des Hétéromères avec la description des espèces nouvelles. Annales de la Société Entomologique de France (5) 6: 93-142.

Masumoto, K. (1981): Tenebrionidae of Formosa (2). - Elytra 9: 15-52.

Masumoто, K. (1993): Notes and descriptions of Japanese Tenebrionidae, VI. - Entomological Review of Japan 48: 127-136.

Mаsumoто, K. (1996): Two new tenebrionid species (Coleoptera) from the Ryukyu Islands. - Japanese Journal of Entomology 64: 211-214.

Masumoto, K. (1998): New tenebrionid beetles from East Asia (Coleoptera, Tenebrionidae). - Japanese Journal of Systematic Entomology 4: 305-319.

маsumото, K. \& Акіта, K. (2001): New or little-known tenebrionid species from Japan (Part 1). - Entomological Review of Japan 56: 15-22.

Masumoto, K., АкiтA, K. \& Lee, C.-F. (2017): New or little known tenebrionid beetles (Coleoptera) from Taiwan. (14). Descriptions of five new Tarpela species (Tenebrioninae, Helopini) with a diagnostic key to all the Taiwanese species. - Elytra, New Series 7(2): $445-455$.

Masumoto, K., Ando, K. \& AкiтA, K. (2006): New or little known tenebrionid species from Japan (Part 5). A new species belonging to a new genus (Coleoptera: Tenebrionidae: Helopini). - Entomological Review of Japan 61: 33-38.

Masumoto, K. \& Kondo, S. (1984): Check-list of Formosan Tenebrionidae (Col.). - Special Bulletin of the Japanese Society of Coleopterology 1: 1-29.

Matthews, E. G., Lawrence, J. F., Bouchard, P., Steiner, W. E., Ślipiński, Jr. \& Ślipiński, S. A. (2010): 11.14. Tenebrionidae Latreille, 1802. Pp. 574-659. In: Leschen, R. A. B, Beutel, R. G. \& Lawrence, J. F. (eds): Handbook of zoology. Arthropoda: Insecta. Part 38. Coleoptera, beetles. Volume 2. Morphology and systematics (Elateroidea, Bostrichiformia, Cucujiformia partim). - Walter de Gruyter, Berlin.

Medvedev, G. S. (1987): Review of darkling beetles of the genus Cylindronotus Fald. (Coleoptera, Tenebrionidae) of Kazakhstan and Middle Asia. - Proceeding of Zoological Institute AS USSR 170: 99-104.

Nabozhenko, M. V. (2001): On the classification of the tenebrionid tribe Helopini, with a review of the genera Nalassus Mulsant and Odocnemis Allard (Coleoptera, Tenebrionidae) of the European part of CIS and the Caucasus. - Entomologicheskoe Obozrenie 80: 627-668. [In Russian; English translation: Entomological Review 81: 909-942.]

Nabozhenкo, M. V. (2002): Darkling beetles of the tribe Helopini (Coleoptera, Tenebrionidae) of the european part of the CIS and the Caucasus. - Ph Thesis. Zoological Institute of the Russian Academy of Science, Saint Petersburg, 309 pp. 
Nabozhenкo, M. V. (2005): Interstructural correlations in evolution of darkling beetles of the tribe Helopini (Coleoptera: Tenebrionidae). Caucasian Entomological Bulletin 1: 37-48. [In Russian]

Naвozhenко, M. V. (2006) A revision of the genus Catomus Allard, 1876 and the allied genera (Coleoptera, Tenebrionidae) from the Caucasus, Middle Asia, and China. Entomologicheskoe obozrenie 85: 798-857. [English translation: Entomological Review 86 1024-1072] https://doi.org/10.1134/S0013873806090065

Nabozhenко, M. V. (2007): Taxonomic notes on the genus Catomus Allard, 1876 (Coleoptera, Tenebrionidae: Helopini) with description of a new species from Afghanistan. - Caucasian Entomological Bulletin 3: 41-45.

Nabozhenко, M. V. (2012): A review of the genus Nalassus Mulsant, 1854 (Coleoptera: Tenebrionidae: Helopini) of China with new concept of the distribution of the genus. - Caucasian Entomological Bulletin 8: 33-36.

Nabozhenкo, M. V. (2015a): Review of the genus Catomus Allard, 1876 (Coleoptera: Tenebrionidae) in Iran. - Zoology in the Middle East 61: 64-68. https://doi.org/10.1080/09 397140.2014.994307

Nabozhenко, M. V. (2015b): To the knowledge of Helopini (Coleoptera: Tenebrionidae) of Morocco. - Caucasian Entomological Bulletin 11: 33-37.

Nabozhenko, M. V., Keskin, B., Dvadnenko, K. D. \& Alpagut Keskin, N. (2016): The genus Gunarus Des Gozis, 1886 belongs to the subtribe Cylindrinotina (Coleoptera: Tenebrionidae: Helopini). - Caucasian Entomological Bulletin 12: 111-116.

Nabozhenкo, M. V. \& Artoкнin, K. S. (2017): Description of the larva of Nalassus (Helopondrus) sareptanus (Allard, 1876) and a position of the subgenus Helopondrus Reitter, 1922 in the system of the tribe Helopini (Coleoptera: Tenebrionidae). - Proceedings of the Russian Entomological Society 88: 72-79.

Nabozhenko, M.V. \& Gurgenidze, L.N. (2006): Description of the larva of Cylindrinotus gibbicollis Faldermann, 1837 and notes on the classification of the subtribe Cylindrinotina Español, 1956 (Coleoptera: Tenebrionidae: Helopini). - Caucasian Entomological Bulletin 2: 79-82.

Nabozhenko, M.V. \& Ivanov, S.N. (2015): A new Nalassus Mulsant, 1854 (Coleoptera: Tenebrionidae: Helopini), the first representative of the genus from the Russian Far East. - Zootaxa 3955: 137-141. https://doi.org/10.11646/zootaxa.3955.1.9

Nabozhenko, M.V. \& Keskin, B. (2009): Two new species of the genus Gunarus Des Gozis, 1886 (Coleoptera: Tenebrionidae: Helopini) from Southern Turkey. - Zootaxa 2170: 53-60.

Nabozhenko, M.V. \& Löвl, I. (2008) Tribe Helopini. Pp. 241-257. In: Löbl, I. \& Smetana, A. (eds): Catalogue of Palearctic Coleoptera. Vol. 5. Tenebrionoidea. Apollo Books, Stenstrup.

Nabozhenko, M. V., Niкitsky, N. B. \& Aalbu, R. (2016): Contributions to the knowledge of North American tenebrionids of the subtribe Cylindrinotina (Coleoptera: Tenebrionidae: Helopini). - Zootaxa 4136: 155-164. https://doi.org/10.11646/zootaxa.4136.1.7

Nabozhenko, M. V., Niкitsky, N. B. \& Keskin, B. (2017) Taxonomic review of the genus Euboeus s. str. Boieldieu, 1865 (= Probaticus s. str. Seidlitz, 1896, syn. n.) (Coleoptera, Tenebrionidae). - Zootaxa 4358, 494-506. https://doi.org/10.11646/zootaxa.4358.3.6

NAKANE, T. (1963): New or little known Coleoptera from Japan and its adjacent regions, XIX. - Fragmenta Coleopterologica 6-7: 26-30.

Nakane, T. (1979): New or little-known Coleoptera from Japan and its adjacent regions. XXXI. - Fragmenta Coleopterologica 25-28: 112-114.

Pic, M. (1925): Nouveautés diverses. - Mélanges Exotico-Entomologiques 44: 1-32. 
Purchart, L. \& Nabozhenko, M. V. (2012): Description of larva and pupa of the genus Deretus (Coleoptera: Tenebrionidae) with key to the larvae of the tribe Helopini. In: HÁJEK, J. \& BEzDĚK, J. (eds): Insect biodiversity of Socotra Archipelago. - Acta Entomologica Musei Nationalis Pragae 52(Suppl. 2): 295-302.

ReitTer, E. (1922): Bestimmungstabelle der palaearktischen Helopinae (Col. Tenebrionidae). - Wiener Entomologische Zeitung 39: 1-44, 113-171. https://doi.org/10.5962/bhl.part.2572

Schawaller, W. (2012): Afrohelops gen. nov. (Coleoptera: Tenebrionidae: Helopini) from relict montane forests in Kenya and Mozambique. - Annals of the Ditsong National Museum of Natural History 2: 75-79.

Shin, S. C., Bae, W. I., Won, G. J., OH, G. S., PArk, J. D. \& Lee, B. Y. (2000): Catalogue of species in insect collection of Forest Research Institute, II. Insects except Lepidoptera. - Korean Forest Research Institute, Seul, 173 pp.

Steiner, W. E. (2009): The Helopini (Coleoptera: Tenebrionidae) of Virginia. Pp. 331-339. In: Roble, S. M. \& Mitchell, J. C. (eds): A lifetime of contributions to Myriapodology and the natural history of Virginia: A festschrift in honor of Richard L. Hoffman's 80th birthday. - Virginia Museum of Natural History Special Publication No 16, Martinsville, VA, USA.

Received May 10, 17, 2018, accepted June 30, 2018, published October 12, 2018 


\title{
A Magyar Természettudományi Múzeum gyászbogártípusainak (Tenebrionidae) katalógusa \\ Type catalogue of darkling beetles (Tenebrionidae) preserved in the Hungarian Natural History Museum
}

\author{
by Ottó MerkL, Aranka Grabant \& Zoltán Soltész
}

The Hungarian Natural History Museum (HNHM) houses one of the largest and most complete Tenebrionidae collections of the world, thanks to Zoltán Kaszab (1915-1986), the Museum's former General Director and the most prominent figure of Hungarian coleopterology. The book is a commemoration of the centenary of his birthday.

The introduction summarises the history of the Hungarian Natural History Museum, its Coleoptera Collection and the scientific activity of Zoltán Kaszab.

Type specimens constitute the scientifically most valuable assets of the collection. The catalogue contains types of all the species, subspecies, variations and aberrations which have ever been described in the family Tenebrioni-

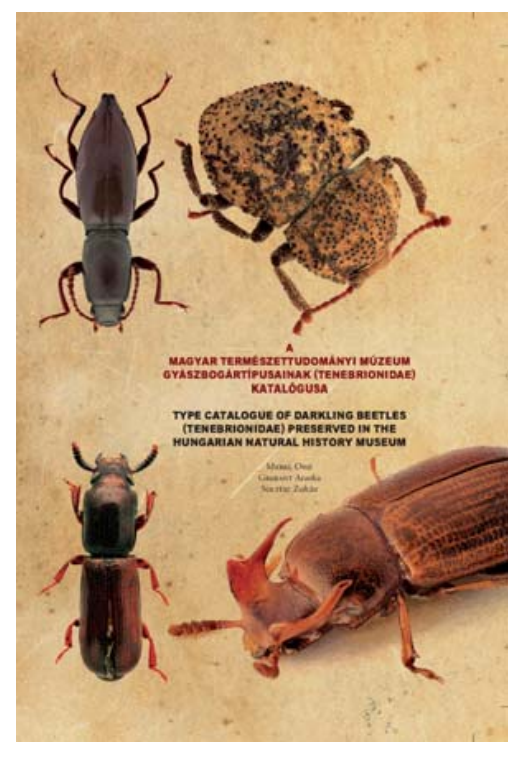
dae, and kept in the HNHM, including those already assigned to other families, as well as those which were described in different families but are now members of Tenebrionidae. A total of 21,313 type specimens belonging to 5,941 names are listed herein, including 1,222 holotypes, 4 neotypes, 88 lectotypes, 4,914 syntypes, 86 allotypes, 248 paralectotypes and 14,751 paratypes. The list of the names is followed by a complete list of the 1,212 publications containing the original descriptions.

Merkl, O., Grabant A. \& Soltész Z. (2015): A Magyar Természettudományi Múzeum gyászbogártípusainak (Tenebrionidae) katalógusa. Type catalogue of darkling beetles (Tenebrionidae) preserved in the Hungarian Natural History Museum. - Hungarian Natural History Museum, Budapest, 735 pp.

ISBN 9789639877238 [hardcover]

Orders should be sent to:

The Library, Hungarian Natural History Museum

H-1083 Budapest, Ludovika tér 2, Hungary

Fax: (36-1) 3172320, e-mail: angela@nhmus.hu

Price: 9990 HUF, 30 EUR 